\title{
PETROLOGY AND RADIOGEOLOGY OF THE STRIPA PLUTON
}

Harold Hollenberg, Steve Flexser, and Lennart Andersson

\author{
Earth Sciences Division \\ Lawrence Berkeley Laboratory \\ University of California \\ Berkeley, California 94720
}

\section{DISCLAIMER}

\begin{abstract}
This report was prepared as an scoount of work sponsoned by an eseacy of tbe United States Government Neither the United States Government nor any apeacy thereof, not any of their employees, makes any warrany, express or implied, or aswumes any legal libility or respontibility for the accuracy, completeness. or usefulness of any information, appartat, product, or process disclosed, or represents that its use would not infringe privately ownod rights. Reference herein to any specific commercial product, process, of service by trade anme, trudemark, manufacturer, or otherwise does ant necessurily constitute of imply its endorsement, reconinendation, or favoring by the United States Government or any atsency thereof. The views and opinions of authors expressed herein do not necessarily state or reflect those of the United States Government of any agency thereof.
\end{abstract}

December, 1980

This work was supported by the Assistant Secretary ior Nuclear Energy, Office of Waste Isolation of the U.S. Department of Energy under contract DE-AC03-76SF00098. Funding for this project was administered by the Office of Nuclear Waste Isolation at Battelle Memorial institute, Columbus, Ohio.

\section{MOTICE}

POATIONS OF THIS BEPONT ABE RLEGLBLE.

it has been reproduced from the best arrilable copy to permit the broadest possible availabitity. 
rhis repart is one of a series docuilenting the resulcs of the Swedish-American cooperative research proyral, II which the cooperatiny scientists explore the geological, geophysical, hyd:ological, geochenical, end structural effects aricicipated from the use of a large crystalline rock mass as a geoloyic rejository for melear waste. This progranl has betn sponsored by the Swedish Nuclear Power utilities through the swedish iuclear fuel Suphly curpany (SKBF), and the U.S. Departinent of Eneryy (DOE) throuyh the Lamence Berieley Laburdury.

The illicilal invescigators are L.B. Ni isson and O. Veyemian for SKBF, and H.G.H. Cook,

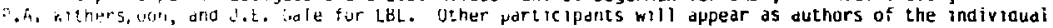
reports.

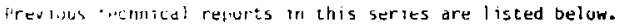

1. Swedisil-iderican Couperat iye Prugrall un Radioactive haste Storaye in Mined Cavarns by

F.A. nitherspoon afld U. Degerian. (IBL-7049, SAC-01).

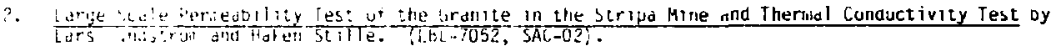

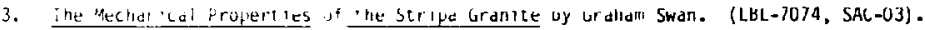

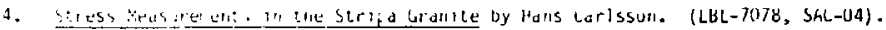

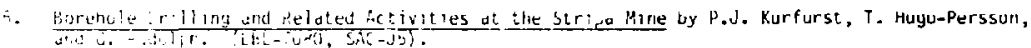

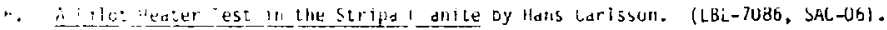

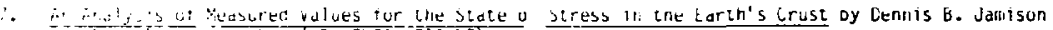
(ir t:

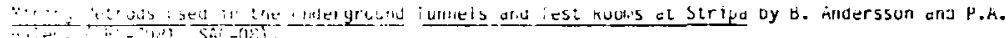

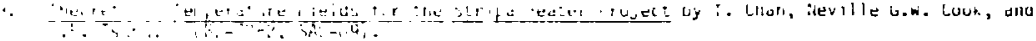

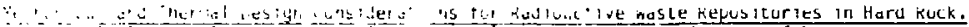

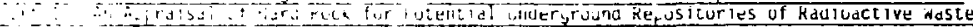

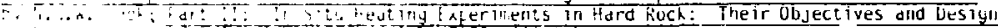

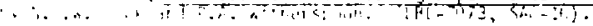

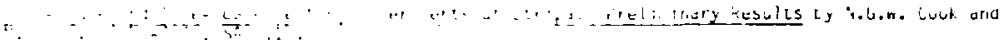

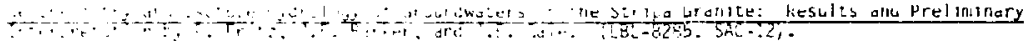

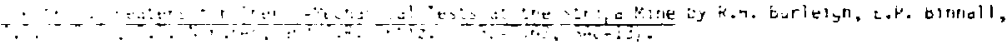

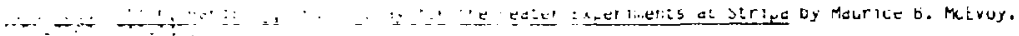

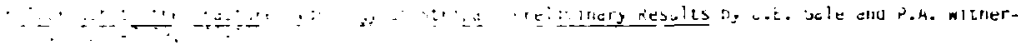

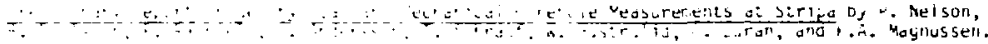

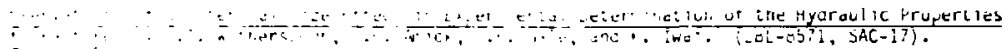

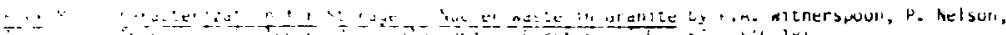

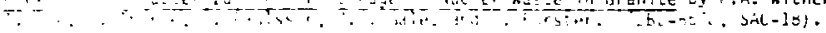


20. Characterization of Discontinuities in the Stripa Granite--T ime Scale Heater txperinent by R. Thurpe. (LBL-7083, SAC-20).

21. Geology and Fracture System at Stripa by A. Okliewicz, J.E. Gale, R. Thorpe, and B. Pali isson. (LBL-8907, SAC-21).

22. Calculated Themally Induced Displacements and Stresses for Heater Experienents at Stripd Dy T. Chan and N.G.W. Cook. (LBL-7061, SAC-22).

23. Validity of Cubic Law for Fluid Flow in a Deformable Rock Fracture by P.A, Witherspoon, J. Wong, $\bar{K}$. Iwai, and J.E. Gale. (LBL-9557, SAC-23).

24. Detemination of In-Situ Themal Properties of Stripa Granite from Tenperature Heasurements in the Ful1-Scale Heater Experiments: Methods and Primary Results by J. Jeffry, T. Chan, N.G. i. Cook and P.A. Witherspoon. (LBL-8424, SAC-24).

25. Instrumentation Evaluation, Calibration, and Installation for Heater Tests Simulatiny Nuclear Waste in Crystalline Rock, Sweden by T. Schrauf, H. Pratt, E. Simurson, H. Hustrulid, P. Nelsun, A. DuBois, E. Binnall, and R. Haught. (LBL-8313, SA.,-25)

26. Part I: Some Results From a Field Invcstigat on of Thermo-Mechanical Loading of a kock Mass wisen Heater Canisters are Emplaced in the Rock by H. Kood. Part II: The Application of Fiela Dat fruk Heater Experiments Conducted at Stripa, Sweden for Repositary Design by M. Hood, H. Larlsson, alio P.H. NeTsor. (LBL-9392, SAC-26).

27. Progress with Field Investigations at Stripa by P.A. Witherspoon, N.G.W. Cook, ano j.t. Gale (LBL-1055S, SAC-2T).

28. A :aboratory Assessment of the Use of Borehole Pressure Transients to Measure the Pernitdullity of Fractured Rock Masses by C.B. Forster and J.E. Gile. (LBL-8674, SAC-28).

29. Thermal and Thermomechanical Data for In Situ Heater Experinents at Stripd, Sweaen Dy T. Chan, E. Binnal,, P. Nelson, 0. Wan, C. Weaver, K. Ang, J. Braley, and M. McEvoy. (LBL-L1477, jAC-23).

30. The Effect of Radon Transport in Groundwater Upon Gama Ray Borehole Lays by P.H. Melson, R. Rachiele, and A. Smith. (LBL-11180, SAC-30).

31. Strenqth and Permeability Tests on U1tra-Lirge Stripa Granite Core by R. Tnorpe. D.J. Watkiris. H.E. Ralph, R. Hsu, and S. Flexser. (LBL-11203, SAC-31).

32. U1trasonic and Acoustic Emission Results from the Stripa Heater Experients. Part I: 2 iross-Hole Investigation of a Rock Mass Subjected to Heating by B.N.P. Paulssurl dns M.S. Kiny. Part li: Acoustic Emission Monitoring During Cool-Down of the Stripa Heater Experinent by R. Rachiele. (LBL-10975, SAC-32).

33. Nunerical Modeling to Assess Possible Influence of the Mine Upeninys un Far-Fiela In Sicu Siress Measurements at Stripa by T. Chan, V. Guvanasen, and N. Littiestone (LBL-1246G, SAC-33).

34. A Field Assessment of the Use of Borehole Pressure Transients to Medsure Lne Periueadility uf Fractured Rock Masses by C.B. Forster and J.E. Gale. (LBL-11829, \$AC-34).

35. Water Inflow into Boreholes Ouring the Stripa Experiments by F.H. Nelson, R. Kachiele, J.S. Kelier and H.S. Cartsson (LBL-12547, SAC-35). 
LIST OF FIGURES .................................. vi

LIST OF TABLES ......................... ix

ABSTRACT ...............................

1.0 INTRODUCTION . . . . . . . . . . . . . . . 1

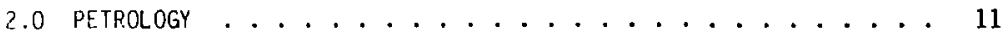

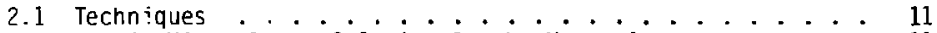

2.2 Matrix Mineralogy of Stripa Quartz Monzonite ...... 11

2.3 Fracture Fillings in Stripa Quartz Monzonite ....... 16

2.3.1 Descrintion of Materials .......... 17

2.3.2 Breccias ................. 20

2.3.3 Fracture Sequences............ 23

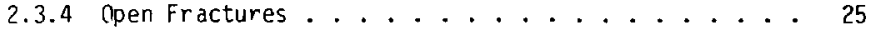

2.3.5 X-Ray Diffraction Analyses of Fracture-Filling

Minera!s................ 25

2.4 iexiure of the Stripa Quartz Monzonite ........ 29

2.5 Other Granitic Rocks in the Stripa Region......... 31

2.6 Lemical Compositions arld Ages of the Franitic Rocks... 32

2.7 leptite and Associated Rocks .... . . . . . . . 37

2.8 Amphibolite and Diabase............... 43

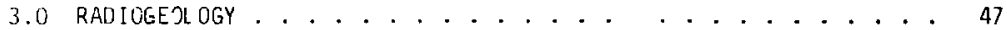

3.1 Instrumentation . . . . . . . . . . . . 47

3.2 Field Procedures . . . . . . . . . . . . 48

3.3 Treatmert of Field Data to Yield K, U, and Th Values . . 48

3.4 Laborat ory Gamma-Spectrometry Results............ 49

3.5 Fiss ion Track Radiography Results . . . . . . . . . . . 52

3.5 Discussion of Radioelement Data............ 60

3.6.1 Relative Abundances ............. 60

3.6.2 Variation with Depth.............. 60

3.6.3 Radioelements and the Age of Groundwater...... 64

3.7 Radiogenic Heat Production and Heat Flow ....... 67

4.1 SUMMARY ........................ 73

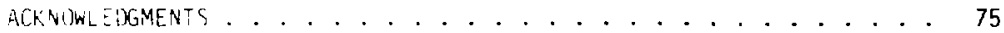

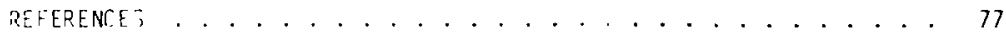

APPENOIX A. IESCRIPTION OF THIM SECTIONS............ A 1

A.I Core Sanples . . . . . . . . . . . . . . . . . . . . A 1

4.? tand Samples from Stripa and Vicinity......... . A17

A.3 tand Samples from other Granitic Massifs near Stripa... A19 
$-v i-$

Page

APPENDIX B. RADIOELEMENT CONTENTS, SURFACE AND UNDERGROUND

MEASUREMENTS, STRIPA ................... 1

APPENDIX C. DESCRIPTION AND LOCATION OF SHEDISH GEOLOGICAL SURVEY

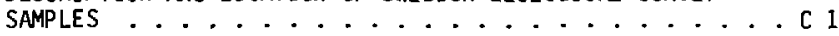


1. (a) Simplified geologic map of the Stripa region showing

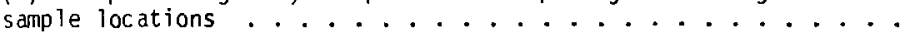

(b) Detailed geologic map of the Stripa area showing sample

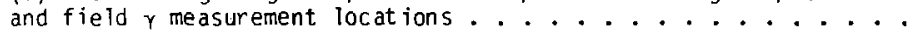

2. Geologic map of the Stripa mine area showing sample and field $\gamma$ measurement locations .............

3. Geologic map of the $310 \mathrm{~m}$ level of the Stripa mine showing sample and $\gamma$ measurement locations

4. (a) Geologic map of the $360 \mathrm{~m}$ level of the Stripa mine showing sample and $\gamma$ measurement locations

(b) Westward continuation of Figure $4 \mathrm{a}$, with the appropriate coordinates.

5. Vertical cross-section bearing $N 89^{\circ} E$ through boreholes SBH-2 and $\mathrm{DBH} V-1 \ldots \ldots \ldots$

6. Relative modal abundances of quartz, microciline, and plagioclase, normalized to $100 \%$ of Stripa and neighboring granites . . . . . . . . . . . . .

7. (a) Fine sericite-filled cracks extend ing from primary muscovite grain, in quartz monzonite, S-38; (b) Chlorite an aloque of $(a) \ldots \ldots . . . \ldots$

8. Graritic breccia, $\$-46$, composed of grains of quartz, plagioclase, microctine, and composites of those minerals, fragmented from the parent quartz monzonite . . . . . .

9. [2isplaced twin lame 11 ae in plagioclase grains, in fractured and brecciated quartz monzonite.......... ¿z

10. Mylunitic breccia in contact zone between quartz monconite and dike, S-33.

11. Relative normative abundances of quartz, plagioclase, and $k$-felospar

12. Reldtive abundances by weight of oxides of Fe, Mg, and alkalis 
-vi ii-

Page

14. Intersecting fractures in leptite, S-5.............. 42

15. Wide foliated fracture zone in amphibolite (sample S-9). . . . . 44

16. Calibration curves relating radioelement contents determined by surface and underground $r$-spectral measurements to laboratory radioelement analyses . . . . . . . 52

17. Fission tracks from $U$ in two fine opaque grains in chlorite, in relatively unfractured quartz mon-

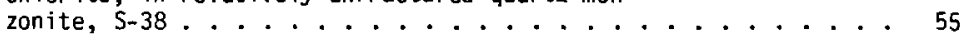

18. Fission tracks from $U$ in euhedral opaque grain and along fine chlorite-filled fractures in fractured and brecciated quartz monzonite, 5-29............... . . 56

19. Anhedral opaque grain on carbonate stringer in fractured grant ic rock adjacent to contact with leptite......... 58

20. Triangular diagram showing relative abundances of radios elements

61

21. Variation of uranium and thorium with depth in the Strip quartz monzonite

62

22. Temperature profile in boreho ie OBH $\vee-1 . \ldots . . . . . . . . .68$

23. Layered models of a possible configuration of the Strip pluton...................... 71 


$$
-i x-X
$$

\section{LIST OF TABLES}

Page

1. Modal composition of granit ic racks from Stripa and neigh-

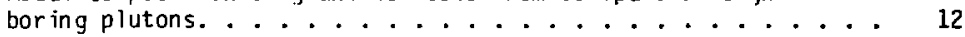

2. Electron microprobe analysis of chlorite grains from sample of Stripa quartz monzonite from $4.60 \mathrm{~m}$ depth in borehole $\mathrm{Nl}$

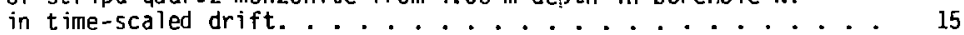

3. X-ray diffraction peaks of whole fracture-filling from ultra-large core .................... 26

4. X-ray diffraction peaks of chlorite-enriched separate from a thick fracture in the east end of the extensometer $\mathrm{jrift}$. . 27

5. X-ray fluorescence major-element analyses of relatively fracture-free granites from Stripa and neighboring plutons . . 33

6. Whole-rock chemical analyses of granitic rocks from other plutons in the Stripa region .............. 34

7. Results of radiometric dating, by the potassium-argon method, of 3 granitic samples from Stripa and vicinity . . . . 38

8. Laboratory $\gamma$ spectral analyses of Stripa rock types ....... 50

9. Mean and standard deviation of radioelement contents ..... 53

10. Values used to calculate apparent ages of waters from Stripa

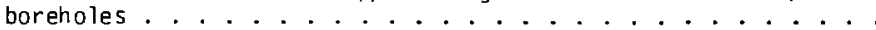


ABSTRACT

To better define the character of the rock encompassing the themomechanical and hydrological experiments at the Stripa mine in central Sweden, and to help determine the size of the Stripa pluton, detailed studies were conducted uĩ the petrology and radiogeology of the quartz inonzonite and adjacent rocks. Petrologic studies emphasized optical petrography, with supplementary $x$-ray diffraction, $X$-ray fluorescence and microprobe analyses. Radiogeologic investigations were based primarily on surface and underground gamma-ray spectrometric measurements of uranium, thorium, and potassium, supplemented hy laboratory gamma-spectrometric analyses and fission-track radiographic determinations of the locations and abundance of uranium in the rock matrix.

Both the quartz monzonite and the metavolcanic leptite which it intruded are strongly fractured. Two stages of fracture filling are evident; an earlier stage encompassing quartz, sericite, feldspar, epidote, and chlorite, and a later stage dominated by carbonate minerals.

The Stripa quartz monzonite is chemically and mireralogically distinct from other plutons in the region. Muscovite is the predominant mica in the quartz monzonite; biotite has been altered to chlorite, hornblende is absent, anc ascessory minerals are scarce. In contrast, in other plutons in the Stripa region biotite and hornblende are prominent mafic minerals and accessory minerals are abundant.

The Stripa quartz monzonite is also considerably more radioactive than the leptite and other plutons in the region. Uranium and thorium abundances are both $\sim 30$ ppm, considerably higher than in "normal" granitic rocks where the thorium-to-uranium ratio generally exceeds 2 . 
$-x j i-$

Potassium-argon dating of muscovite from the Strip quartz monzonite indicates that this rock may te older, at 1691 million years than granitic rock of the neighboring Gusselby and Kloten massifs, whose ages, based on $K-A r$ dating of biotite, are respectively 1604 and 1640 my.

Heat flow and heat productivity considerations show that although Strip quartz monzonite contains high abundances of radioelements, the pluton has little effect on the regional heat flow. If it occurs in a layered plutonic setting, it is not more than $1.5 \mathrm{~km}$ thick; otherwise it may comprise a stock, dike, or border phase that is relatively small compared with the large granitic plutons exposed in the region. 


\subsection{INTRODUCTION}

A number of geomechanical, hydrological, and ge:schemica! tests have been conducted over the past three years in granitic rock at the Stripa mine in central Sweden. More than 30 reports describing the Swedish-American cooperative program have focused on the hydrologic setting and the response of the rock to heatinn. The results of these tests will be used to establish techniques for measuring the hydrological, geomechanical and gecchemical settings of proposed nuclear waste repositories and to determine the properties of a granitic rock mass that would be critical for the long-term isolation of radioactive waste.

To validate the transferability of these techniques and nroperties from Stripa to the evaluation of potential repository masses, it is necersary to know, in some detail, the geologic setting and cetrology of the Stripa plutcr. The general geologic setting was the subject of a report by the Geological Survey of Sweden (0lkievicz et al., 1978), and the fracture system and lithology of the underaround workings were described more recently by 0lkiewicz et al. (1979). The sxperiments at Stripa are beinç conducted in a body of quartz monzonite* within $\sim 200 \mathrm{~m}$ of its contact with older metamorphic rack. Yet, little is known of the size ard confiquration of the Stripa pluton. On the recently published qeologic map of the Lindesberg Southwest quadrangle (Koark and Lundström, 1979), the pluton is shown exposed over a relatively small area ( $0.3 \mathrm{~km}$ radius). However, the extensive cover of glacial debris, as shown on the soils map of the region (Geological Survey of Sweden, 1977), may obscure the true size and shape of the pluton at the

*This usage of the term "quartz monzonite" follows common American nomenclature of igneous rocks. According to classificatior of the IUGS (19:3), however, this rock would be termed "granite." 
surface. The configuration of the contact with depth between the pluton and the metamorphic rock (leptite) is well defined only to the south, afforded by the workings of the old iron mine (01kiewicz et al., 1978, 1979). Corisacts to the north, west, and east are concealed at the surface and unexplored at deptn. Thus, it is unknown whather the granitic ruck mass at Stripa is, anong other things, a dike-like body, a stock, or the exposed portion of a much larger piuton, and therefore the position of the experiments within the pluton also remains in question.

To help answer these questions, a program of geological studies was started in the summer of 1979 to determine the size, configuration and composition of the Stripa pluton. Samples of graititic and metamorphic rocks were collected from the surface and underground at Stripa and at other piutons within the Lindesberg region.* (The regional sample locations are shown in Fig. 1, those closer is the Stripa mine in 5 ig. 2, and underground in Figs. 3 and 4). Samples if coies were dlso selected from the inclined holes $58 \mathrm{H} 1$ and 2 , drilled from the surface toward the experimental area, and from the vertical hole DBH $V i$, drilled to a length of $\sim 470 \mathrm{~m}$ from the mine's $410 \mathrm{~m}$ levei; holes SBH-2 and JNH V-l are shown in cross section, Fig. 5. This set of samples then covers a vertical extent from the surface to a depth of riearly $900 \mathrm{~m}$ and encompasses predominantly quartz minzonite and leptite as weil as pegmatite, diabase, and anphibolite. The sample set also contains representatives of the classes of fractures encouniered in the Stripa pluton: thos'a filled predominantly by ch!orite, those oy epidote aus sericite, ant those by quartz and carbonate

\footnotetext{
*A large number of the samples from other plutons and their major oxide analyses were kindly provided oy I. Lundström of the Geological Survey of Sweden (SGU). The essription of these samples is included as Appendix C.
} 


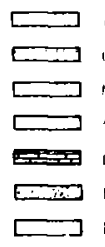

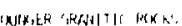

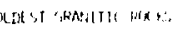

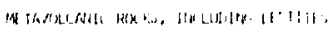

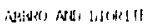

L. IMESTOSHE NID MNHHLL

NETAEDTHLHTAPY INXE:

DIAMSE

MAF MUPBEF

$$
\begin{aligned}
& 1 \\
& 2 \\
& 3 \\
& 4 \\
& 5 \\
& 6 \\
& 1 \\
& 8 \\
& 9 \\
& 10 \\
& 11 \\
& 17 \\
& 15 \\
& 14
\end{aligned}
$$

MAP E PUISHC

$$
\begin{aligned}
& \text { II } \left.\gamma^{x}+1-\right] \\
& 1 / n-10 \\
& |r|-1 \mid \\
& 17,27 \\
& \text { (. } 75-9 \\
& \text { ( } 4,11 \\
& \text { 1. } M \cdot 1] \\
& \text { st } 46 \\
& \text { का } 141 \\
& \text {, } 14 \\
& 1 \pi, 4 \\
& 1 / 1 \% \\
& \text { int is } \\
& 121
\end{aligned}
$$
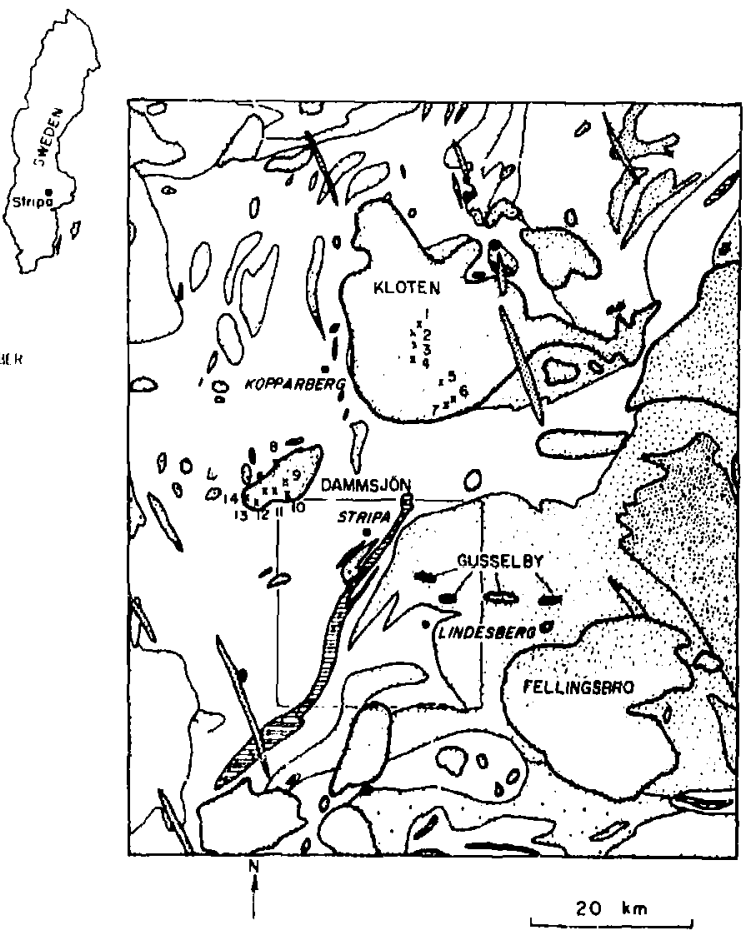

XBL 814-9185

Fig. 1(a). Simplified geologic map of the Stripa region showing sample locations. Area within the square in the map is enlarged and shown as Fig. 1(b). Geologic base map from the Bedrock Map of Swcden, published by the Swedish Geological Survey, 1958, and the Geological Map of Lindesberg SW Quadrangle, also published by S.G.U., 1979. 


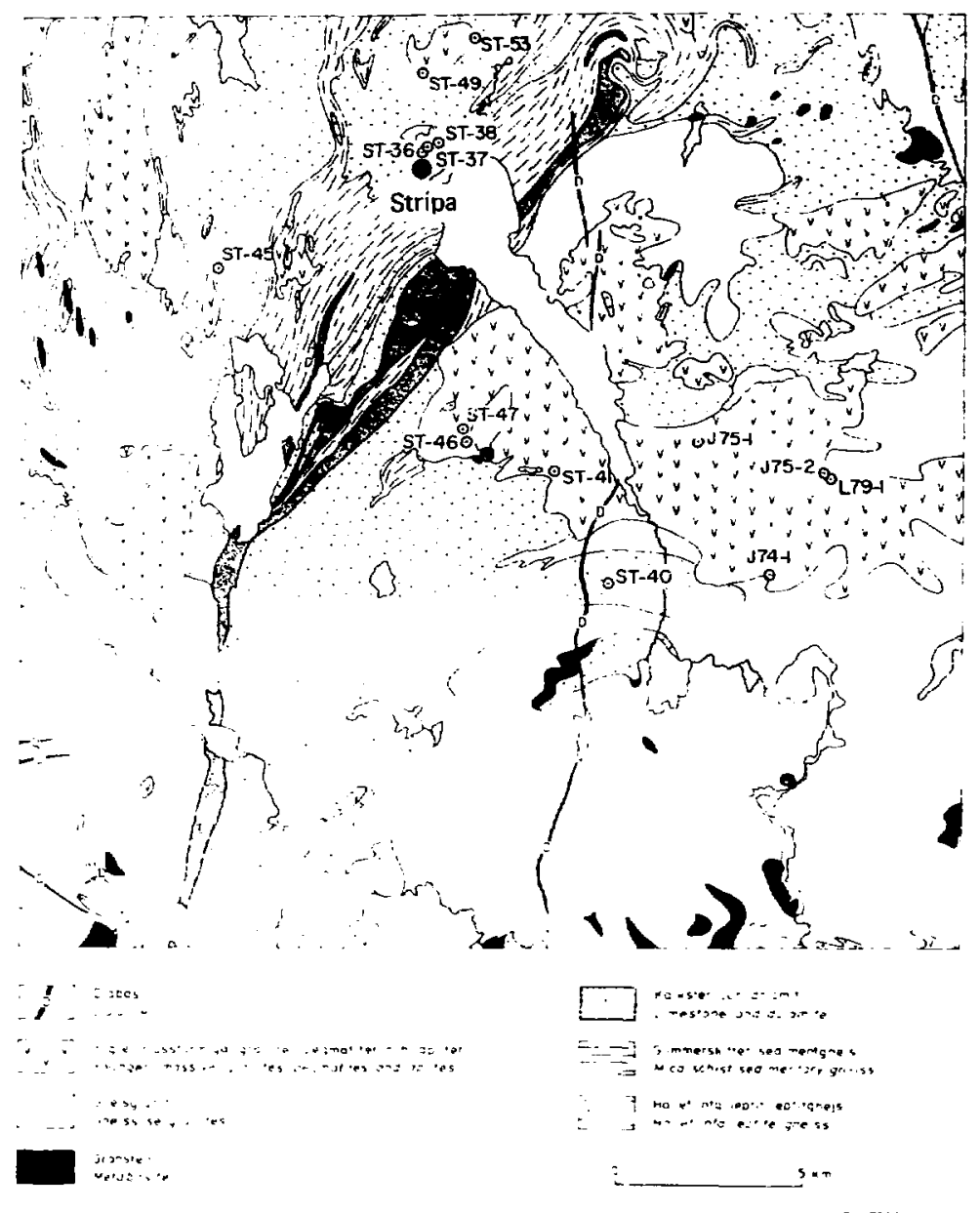

X8: 7310-12564A

Fig. l(t). More detailed gevlogic map of the Stripa area showing sample and field gamma measursilent locations. Geologic base from 01 kiewicz et al., 1978. 


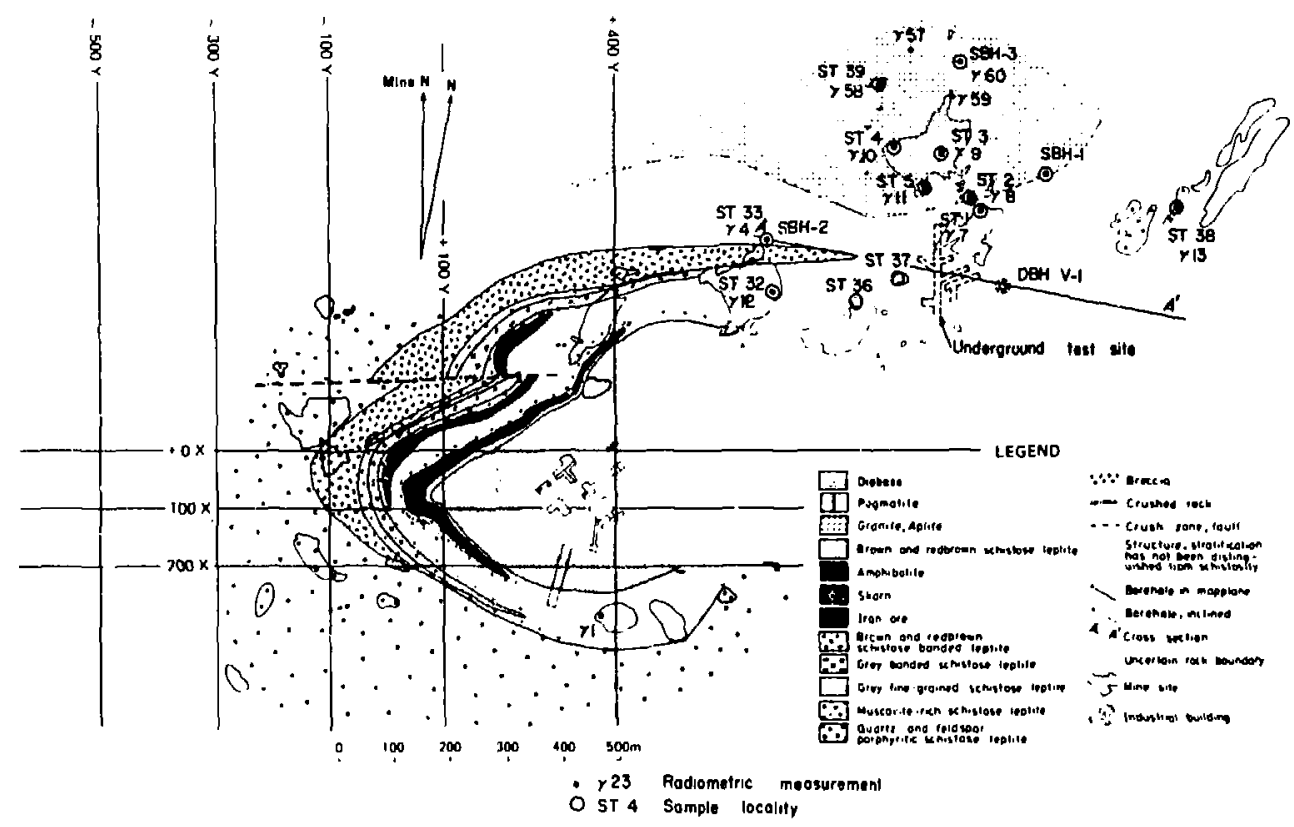

XBL $8010-7372 A$

Fig. 2. Geoiogic map of the Stripa mine area showing sample and field gamma measurement locaiions. Geologic base fror 0lkiewicz et al., 1978. 


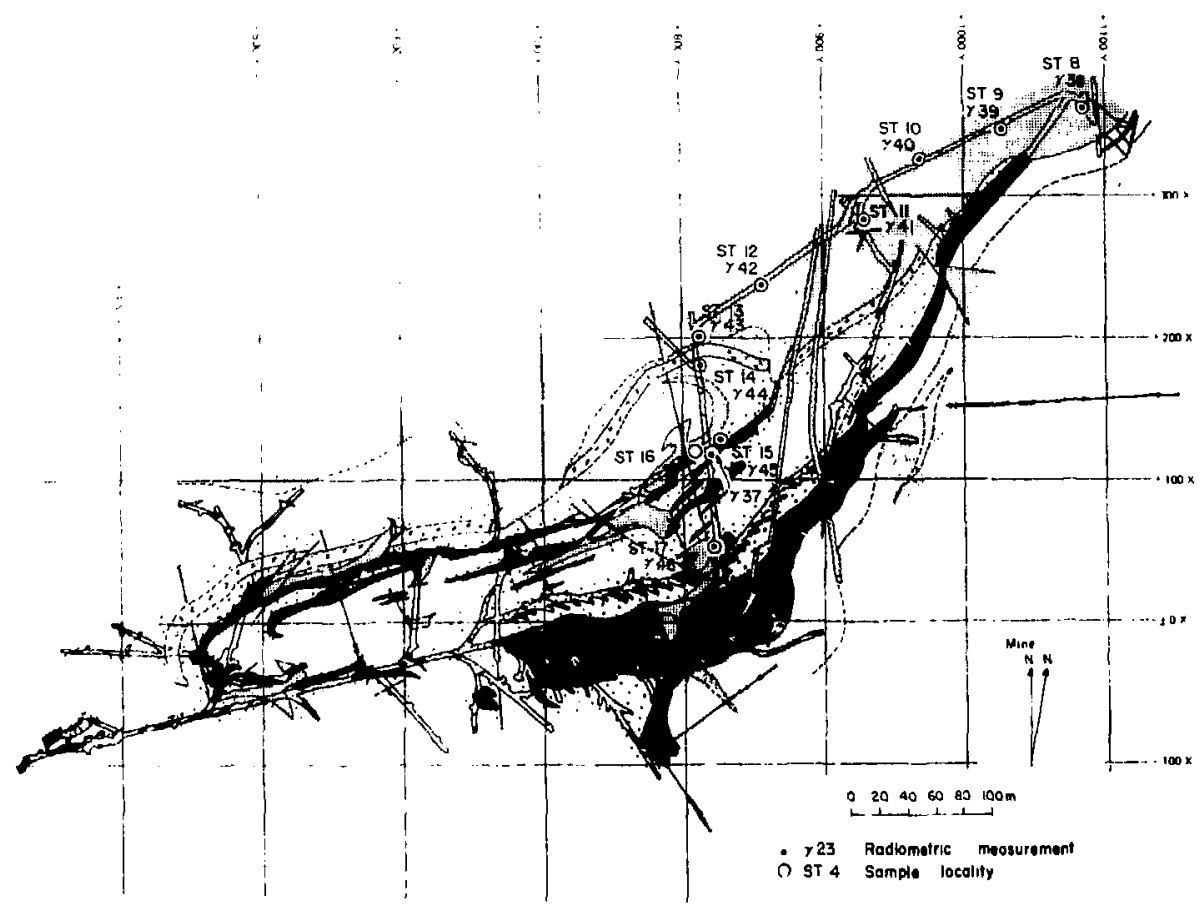

Fig. 3. Geologic map of the $310 \mathrm{~m}$ level of the Stripa Mine showing sample and gamma measurement locations. Geologic base from 01 kiewicz et a1., 1978. Legend is the same as in Fig. 2. 


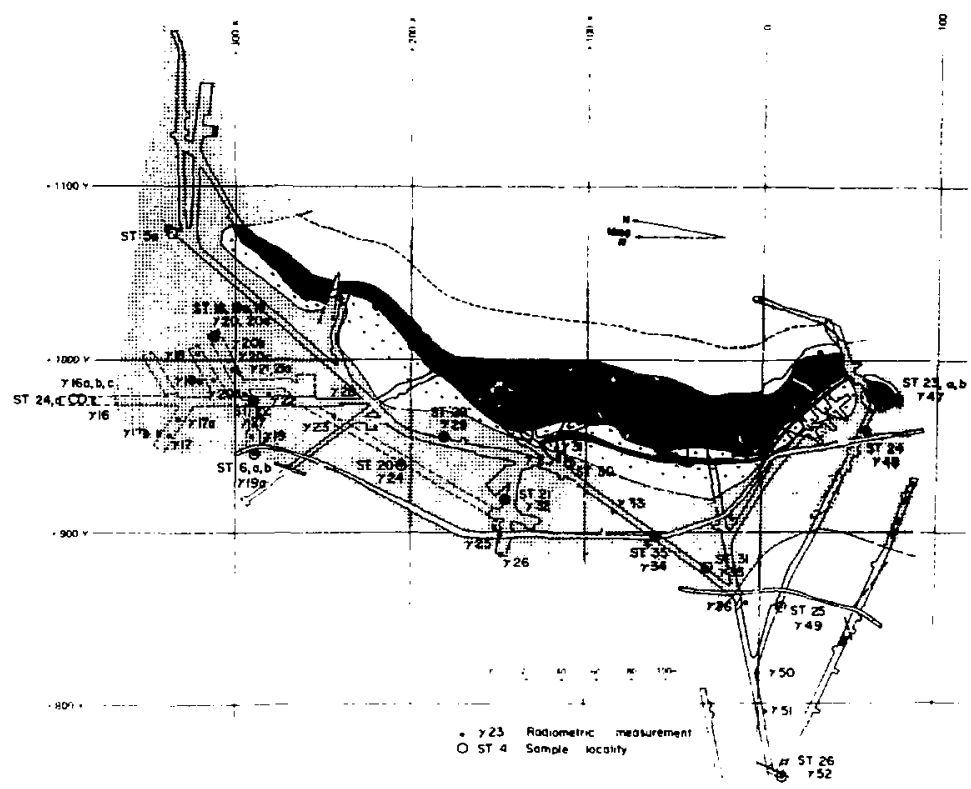

19. $x: 5-\div 359$

Fig. 4(a). Geologic map of the $360 \mathrm{~m}$ level of the Stripa mine showing sample and gamma measurement locations. Geologic base from Olkiewicz et al., 1978. Legend is the same as in Fig. 2. 


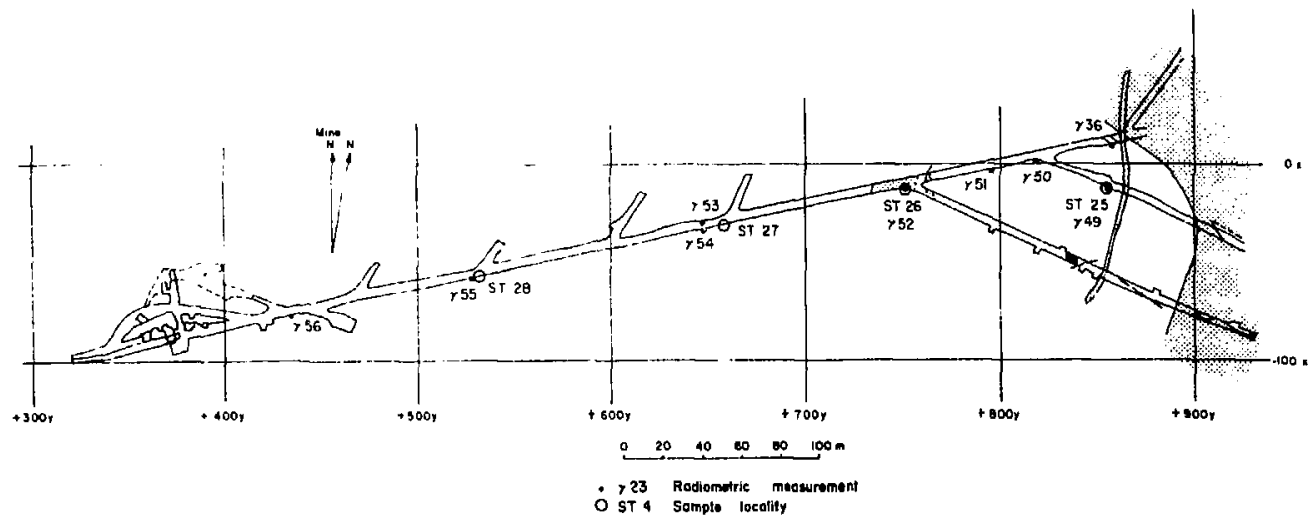

Fig. 4(b). Westward continuation of Fig. $4(a)$, with the appropriate coordinates. The axis of the figure is rotated $90^{\circ}$. $\mathrm{N}=\mathrm{C}^{\mathrm{e}} \mathrm{\text {The }}$ area of overlap of Figs. $4(a)$ and $4(b)$ includes sample sites ST-25 and ST-26. Legend is the same as in Fig. 2. Geologic base from Olkiewicz et al., 1978. 


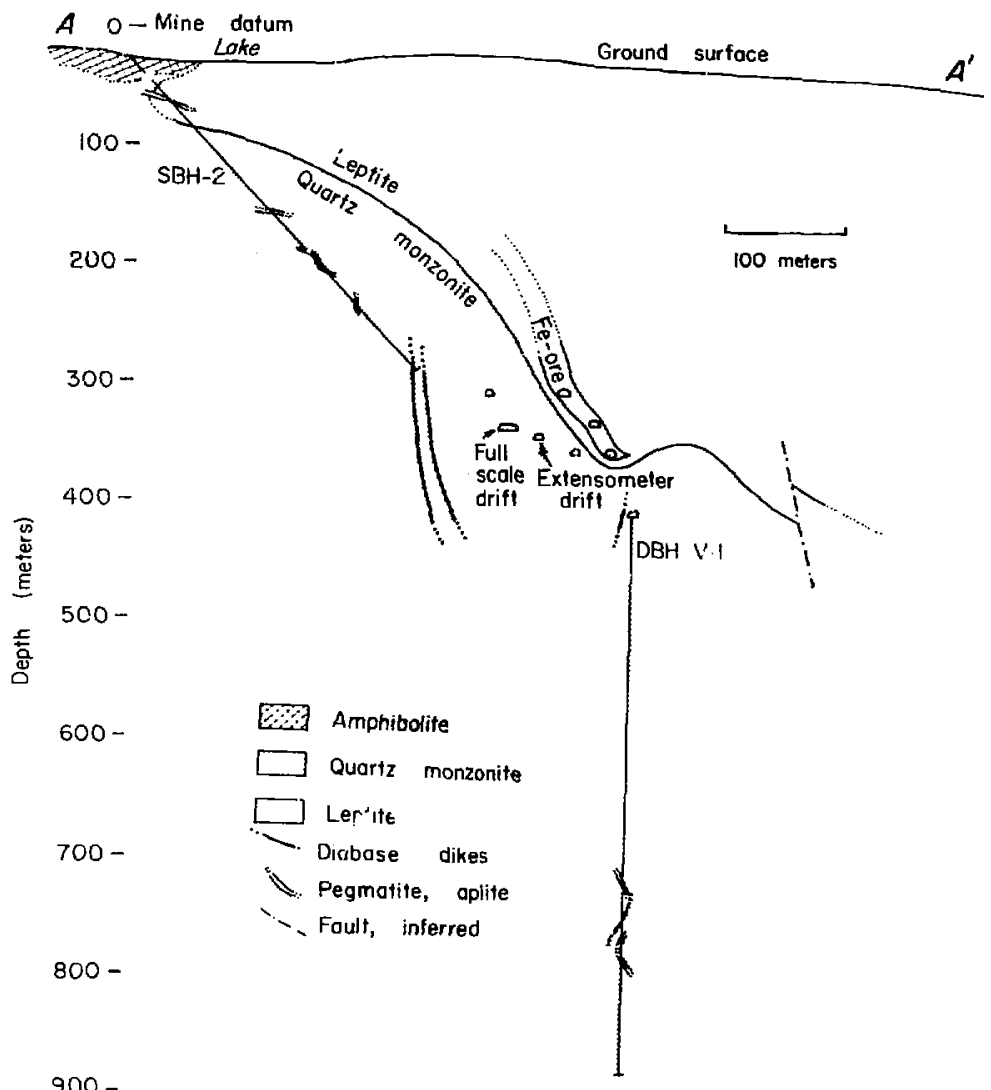

XBL $812-8006$

Fig. 5. Vertical cross-section bearing $N 89^{\circ} \mathrm{E}$ through boreholes $\mathrm{SBH}-2$ and $\mathrm{DBH} \mathrm{V}-1$. 
minerals. At many locations on the surface and underground, hand specimens were oriented at the time of collection for strike and dip, to permit subsequent petrofabric determinations.

Besides collecting surface and subsurface samples, field radicmetric measurements were made with a portable gamma-ray spectrometer to determine the uranium, thorium, and potassium concentrations of the vaijous rock types. These measurements give preliminary indications of the geochemical hanogeneity of the plutoli and help provide the basis for the determination of the aye of groundwater by the ${ }^{4} \mathrm{He}$ method. These data also permit calculation of the radiogenic heat production, a parameter that, when combined with the measured conductive heai flow, may be used to estimate the effective thickness of the pluton.

This report emphasizes, first, the petrology of Stripa rocks and, se ond, their radiogeology. Petrological results are based on petrographic examinations of tin in sections of the various rock types at Stripa and in the surrounding reyion. The results of surface and underground radiogeological surveys are also presented. The location and abundance of uranium in fractures and in relatively unfractured rock have been discerned by the fissiontrack method. This provides a measure of the distribution of the ultimate parent element of ${ }^{22} 2 \mathrm{Rn}$, high contents of which were observed in water from drill holes in the experimental area (Nelson et al., 1980). 


\subsection{PETROLOGY}

\subsection{Techniques}

Petrographic interpretation of thin sections was a major focus of this portion of the study, and descriptions of individual thin sections have been compiled in Appendix $A$. This work has been supplemented by $x$-ray diffraction and microprobe analyses, and by $X$-ray fluorescence chemical analyses of several of the granitic rocks. Also, fission-track radiography was used to determine the location and abundance of uranium in several samples.

\subsection{Matrix Mineralogy of Stripa Quartz Monzonite}

Stripa quartz monzonite is predominantly a grey or reddish, medium to finegrained, relatively uraniferous granitic rock of Proterozoic age. It shows abundant fracturing and deformation on a microscopic scale and frequently on a macroscopic scale as well. On the basis of both chemical composition (see Section 2.6) and relative abundance of its primary minerals, it is more accurately classified as a quartz monzonite than a "granite" (see footnote, p.1).

The granitic matrix--a term designating the primary minerals that crystallized from the melt, as opposed to secondary alteration minerals or fracturefilling minerals--is composed mainly of quartz, plagioclase, and microcline, with lesser muscovite and biotite (now altered to chlorite), and accessory opaque minera 15, garnet, and zircon.

Table 1 shows the mineral composition of Stripa quartz sonzonite samples, all but one relatively unfractured, along with compositions of neighboring plutons. These results are also plotted in Fig. 6, illustrating the relative abundances of quartz, plagioclase, and microcline. 
Table 1. Mineral composition (modal analyses based on point counts) of granitic rocks from stripa and neighboring plutons. Stripa samples are of relatively unf ractured quartz monzonite, with the exception of $E$ lib.

\begin{tabular}{|c|c|c|c|c|c|c|c|c|c|c|c|c|c|c|}
\hline & \multicolumn{6}{|c|}{ Stripa } & \multicolumn{3}{|c|}{ Gusselby } & \multicolumn{3}{|c|}{ Kloten } & \multicolumn{2}{|c|}{0 anms jön } \\
\hline & $5-12$ & $5-38$ & E7-2 & $E 14 b$ & E29b & E1] & $375-1$ & $374-1$ & L79-1 & C75-11 & C75-9 & $175-10$ & J75-14 & J75-9 \\
\hline Qtz & 37.1 & 35.3 & 35.8 & 28.7 & 34.1 & 41.1 & 38.2 & 33.8 & 29.1 & 40.4 & 44.3 & 32.6 & 34.5 & 31.6 \\
\hline Plag & 32.0 & 35.1 & 27.6 & 32.8 & 26.7 & 25.9 & 24.8 & 19.0 & 31.1 & 24.3 & 25.3 & 25.0 & 30.0 & 38.9 \\
\hline$k-f s p$ & 22.2 & 21.5 & 25.4 & 34.4 & 32,9 & 18.0 & 28.2 & 43.7 & 36.1 & 20.7 & 26.2 & 41.8 & 31.0 & 17.3 \\
\hline $\begin{array}{l}\text { Musel } \\
\text { Seric }\end{array}$ & 7.4 & 4.0 & 6.4 & 3.2 & 3.9 & 3125 & 1.2 & 1.5 & 0.5 & - & $*$ & - & 1.7 & - \\
\hline Chlor & 1.3 & 4.1 & 4.5 & 2.8 & 2.4 & & \}$_{7.5}$ & \}$_{1.6}$ & \}$_{3.2}$ & $<1$ & ८1 & \} 0.6 & $<1$ & 1.9 \\
\hline Biot & - & - & - & - & - & - & & & & 12.6 & 4.2 & & - & 7.2 \\
\hline Ariph & - & - & - & - & - & - & - & - & $=$ & $<0.5$ & - & - & - & 1.7 \\
\hline Sphene & - & - & - & - & - & - & - & - & - & 1.5 & - & - & - & 0.8 \\
\hline Access & $<1$ & $<1$ & $\$ 1$ & $<1$ & <1 & 2.4 & $८ 1$ & 61 & $<1$ & $<1$ & $<1$ & $<1$ & 2.6 & 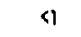 \\
\hline &,$(, 2)$ & $(E, F, G)$ & $(F, 0, G)$ & (C) & $(C, 0, F)$ & $(C, 0)$ & $(Z, F, C, 0)$ & $(0,2, A)$ & $(Z, E, C, 0)$ & $(A, Z, F)$ & $(0,2)$ & (0) & $(0, E)$ & $(0, E, N)$ \\
\hline
\end{tabular}

a Accessory minerals; 0 - upaques; C - carbonate; E - epidute; F - fluorite; Z - zircon; G - garnet; A - apatite

Samples with $f$ prefix are from the extensometer holes drilled in the full-scale and extensometer orifts, See Appendix $A$ for locations and descriptions of other samples. 


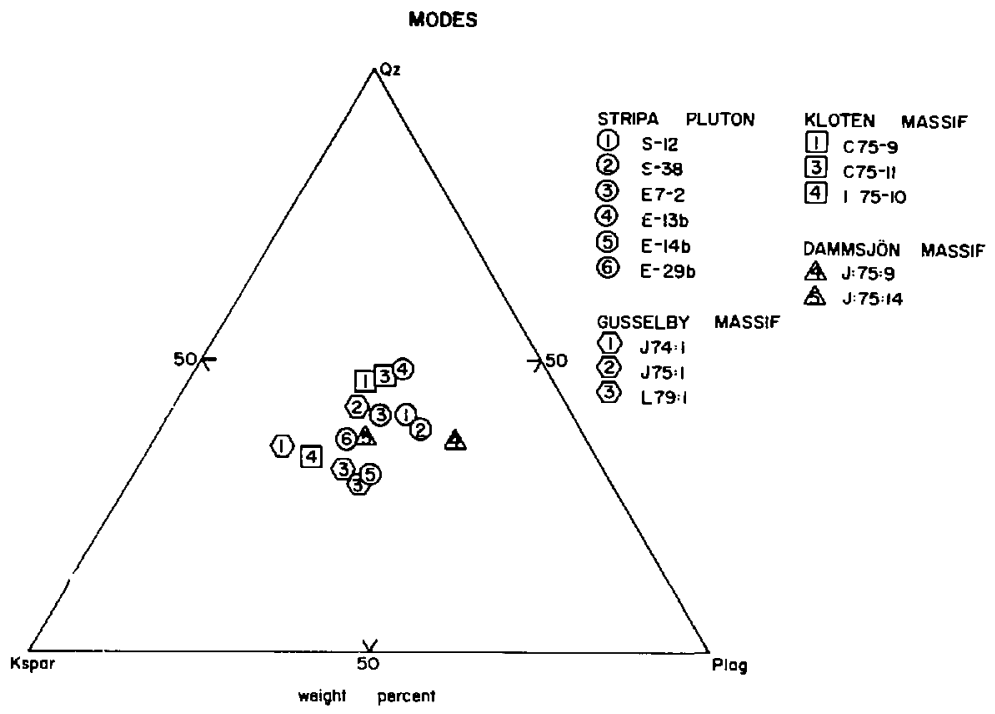

XBL $814-9189$

Fig. 6. Relative model abundances of quartz, microcline, and plagioclase, normalized to $100 \%$ of Stripa and neighboring granites. 
Oligociase is the probable species of piagloclase present in the quartz monzonite, judqing from occurrences in chemically similar granites, and from $x$-ray diffraction evidence. It invariably has a dusty appearance in thin sections, due to growth of minute alteration products. In addition, plagioclase is generally altered in part to sericite (fine-grained, secondary muscovite), or iess of ten to carbonate or clay. Microcline is commonly perthitic or microperthitic, with alteration similar to, but much iess intense than, that in plagioclase, and is not dusty. Microcine is often interstitial to quartz and plagioclase, suggesting that it was the last of these minerals to crystallize. Ouartz is unaltered and clear, and auartz qrains are commionly intergrown in a sutured texture possibly indicative of recrystallization (recrystallization of primary minerals is discussed further in Section 2.4). Hematite is sometimes dispersed as fine dust within feldspar arains, particularly plagioclase, or along grain boundaries or cracks within grains, and is responsible for the red color of many granitic samples.

Muscovite occurs clear and unaltered, as well as partially altered to chlorite ano sericite. Replacement generally advances alono cleavage planes. Biotite, at one time a constituent of the matrix, is now thoroughly altered to dark green chlorite, with occasional brown biotite remnants in chlorite providing the only direct evidence for this replacement. However, chlorite is not known to crystallize as a primary minera? (Deer et al., 1962); it is a common pseudomorphous hydrothermal alteration product of biotite in aranitic rocks where its chenlical composition is oenerally related to that of the oriqinal biotite. Table? lists a partial chemical analysis 
Table 2. Electron microprobe analysis of chlorite grains from sample of Stripa quartz monzonite from $4.60 \mathrm{~m}$ depth in borehoie $\mathrm{NI}$ in timescaled drift. Data averaged over 30 points.

\begin{tabular}{|c|c|c|}
\hline Oxide & Weight $x$ & Std. Deviation \\
\hline $\mathrm{Fe}_{2} \mathrm{O}_{3}{ }^{\mathrm{a}}$ & 38.04 & 1.02 \\
\hline $\mathrm{MgO}$ & 6.25 & 0.33 \\
\hline $\mathrm{SiO}_{2}$ & 24.99 & 0.95 \\
\hline $\mathrm{Al}_{2} \mathrm{O}_{3}$ & 19.09 & 0.65 \\
\hline
\end{tabular}

a Total iron expressed as $\mathrm{Fe}_{2} \mathrm{O}_{3}$. Oxidation state of iron unknown.

The abundance of the four majur elements in chlorite were obtained on the electron microprobe of the Department of Geology and Geophysics ac the University of California at Berkeley. Other elements analyzed were $\mathrm{Na}, \mathrm{Ca}, \mathrm{Zr}$, and $\mathrm{u}$; their oxides were generally present only in trace amounts (<0.1 wt. q). inus, the total percentage by weight of analyzed oxides was $\sim 88.4 \%$; this, with the 10-13\% $\mathrm{H}_{2} \mathrm{O}$ by weight common ly reported in chlorites, brings the total to close to $100 \%$. 
by electron microprobe of chloritized biotite in one sample of quartz monzonite from the time-scaled drift. This chlorite analys is is comparable to analyses of biotites in granites, particularly with respect to values of $\mathrm{Fe}_{2} \mathrm{O}_{3}$ and $\mathrm{MgO}$ (Deer et al. 1962), and is thus consistent with an origin of the chlorite by replacement of primary biot ite.

Garnet, possibly spessart ine-almand ine (min-Fe), is a common accessory mineral in the Stripa quartz monzonite. It occurs generally as isolated unaltered anhedral grains up to 0.5 to $1.0 \mathrm{~mm}$ in diameter; these grains are often anisotropic. In certain aplitic samples, however, garnel grains are much more abundant (see iescription of S-39 in Appendix A), and are of ten rounded and partially alterer to chlorite. Very fine grains of accessory minerals, both opaque sind non-opaque, are common in the chloritized biot ite of the matrix. Pleochroic halos, indicating the presence of elements of the $U$ or Th decay series, are often strongly marked in the chlorite surrounding these grains. The opaque grains haje pot been identified, but the others are probably zircon. Their optical properties do not definitely ident ify them as $z$ ircon, but several grains analyzed by microprobe in the chlorites of Table 2 have high contents of zirconium.

\subsection{Fracture fillings in Stripa Quartz Monzonite}

The stripa quartz monzonite is characterized by a great abundance of fractures and a variety of fracture-filling minerals. Frzucures ranging from well under a millimeter to several centimeters or more in width, as well as wider zones of brecciation, are readily visible in hand sample; but cn?y in thin section does the full extent of fracturing and brecciation become apparent. The great majority of fractures have been completely sealed, but 
in some cases fine openings can be seen in thin section. It is not certain which of these smaller openings may have formed in response to unloading of stresses during core removal, and which existed in the rock prior to drilling.

\subsubsection{Descriptions of Materials}

In hand sample, fracture fillings often can be easily classified on the bas is of coior, with dark green to black, light green, and white fractures most common. In thin section, however, such a simple classification scheme is not possible because the fractures are filled with intergrown minerals in different combinations, anminations that often have similar colors in hand sample.

The most common fracture-filling minerals are chlorite, sericite, quartz, epidote, and carbonate minerals, with fluorite and opaque minerals (often pyrite or hematite) somewhat less common. The thickness of fractures spans a wide $r \geq 7 g e$, from less than $0.01 \mathrm{~mm}(10 \mathrm{~mm})$ to cent imeters. (The terms "stringers," "fine fractures," or " $f$ ine veins" will be used often to refer to fractures less than $0.05 \mathrm{~mm}$ wide.) Generally, only finer fractures are filled with single minerals, usually quartz, sericite, chlorite, or carbonate. Coarser fractures almost invariably are filled with intergrowths of two or more minerals, most often sericite and chlorite. Quartz occurs in combination with any of the fracture-filling minerals. Epidote is usually associated with quartz, chlorite, or sericite, as is carbonate, which is soinet imes intergrown with fluorite as well. Fluorite is usually intergrown with quartz, carbonate, chlarite, or, rarely, epidote. Pyrite is sametimes intergrom with sericite and chlorite. 
In megascopic appearance, the following generalizations are useful, though not foolproof: dark green or black fractures are usually dominated by chlorite; white or near-white fractures by quartz and/or carbonate. Light green fractures are more ambiguous, as they may be a mixture of the above types, or they may be filled mainly with sericite (fine fractures particularly), or with epidote, or, in wide brecciated zones, with a clay-rich fault gouge.

On the finest scale, stringers of sericite and chlorite, quartz and, ?ess commonly, feldspars are abundant, but are not visible megascopica?ly (Fig. 7). They are generally discontinuous and of limited extent, and fill cracks in primary grains or along grain boundaries. These stringers are common in both fractured and relatively unfractured quartz monzonite, and probably relate eicher to an early feformation or to a late stage in the cooling histary of this rock.

Another, more unustial fracture-filling material has been found, although - $d l^{\prime}=l y$, in the stripj quart $z$ monzonite. This material is a hydrocarbon minera!, asphaltite, and is closely associated with calcite and scattered opacide grains in fiaccures in boreho ie SBH-4, arilled from the surface in summer 1980. The asparitite is a nigh-weight variety, a high-temperature distillate that is dark bromn to blick, hard, and highly aromatic (3. Simoneit, University of California, Los Angeles, Institute of Geophysics and Planetary Physics, person.a 1 communication). It is $-1 \mathrm{~cm}$ wide at its most prominent occurrence in borehol: $5 \mathrm{BH}-1$, but in general it has been found in fractures ranging in width 


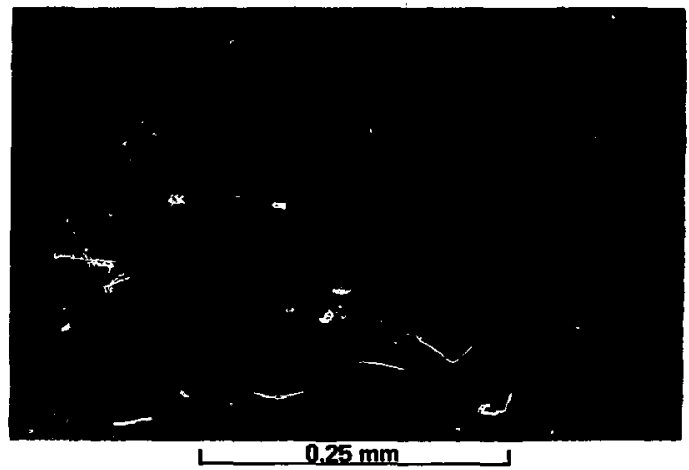

Fig. 7. (A) Fine sericite-rilled cracks (s) extending from primary muscovite grain $(m)$ in quartz monzonite, S-38. Cracks intersect grains of quartz and feldspar. Plane-polarized light.

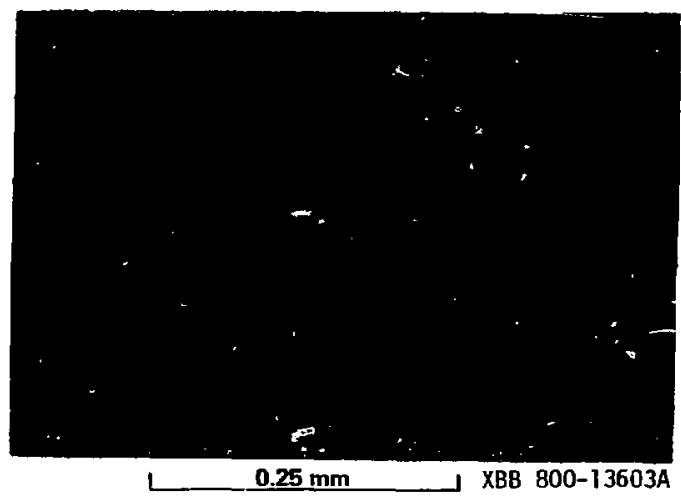

(B) Chlorite analogue of (A). Chlorite stringers (Cs) associated with grain of biotite completely altered to chlorite (c) in quartz monzonite, $\mathrm{S}-26$. Planepolarized light. 
from $1 \mathrm{~mm}$ to $<0.1 \mathrm{~mm}$. Adjacent to these fractures, asphaltite can also be found in very fine interstices between quartz and feldspar grains, and even in cleavage planes in muscovite.

The origin of the hydrocarbon is a puzzle, as is the $t$ ime at which it was deposited in the quartz monzonite. One hypothesis is that its ultimate source was the organic matter in 1 imestones and dolanites, some of wich, now metamorphosed to marble, are exposed within several kilometers of Stripa (Fig. 1b). This organic-derived hydrocarbon could have been mobilized in carbonaterich fluids during metamorphosis, and redeposited in distilled form, along with calcite, in fractures in the quartz monzonite.

Gpaque grains associated with these asphaltite-filled fractures of ten contain siquif icant concentrations of uranium, and these are discussed further in Section 3.5.

\section{2.j. $=$ sreccias}

In wide fractures or fracture zones, breccias containing fragments of the franit is parent rock are usually a major component. Fragments are generally up to severj? הillimeters in diameter (sometimes to several centimeters) and may be anquidi (sample S-30, see Appendix A) or rounded (S-23) (Fig. \&); 7ncluded crystals often show xinked twin or cleavage planes (Fig. 9) and a nign degree of alteration. Materials filling interstices between fragments include chiorite, sericite, epidote, carbonate, hematite and other opaques, fluorite, clay, ard finely conminuted quartz and feldspar grains.

In some prominent wide fractures, breccia is not the dominant filling

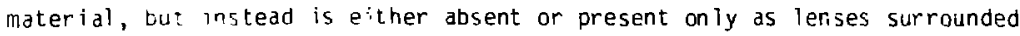




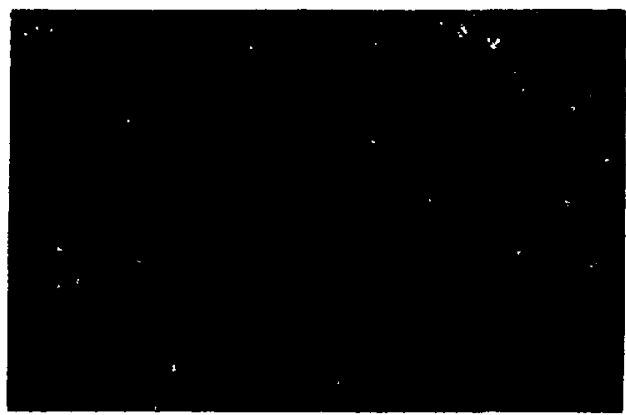

$0.5 \mathrm{~mm}$

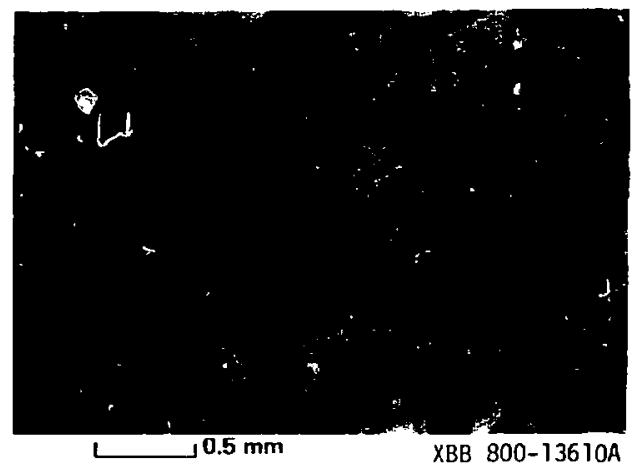

Fig. 8. Granitic oreccia, S-46, composed of grains of quartz, plagioclase, microcline, and composites of these minerals, fragmented from the parent quartz monzonite. Coarser fragments are generally angular, and finer fragments more rounded. Interstitial material is very finely granulated quartz and feldspar, with intergrown chlorite. (A) planepolarized light; (B) cross-polarized light. 


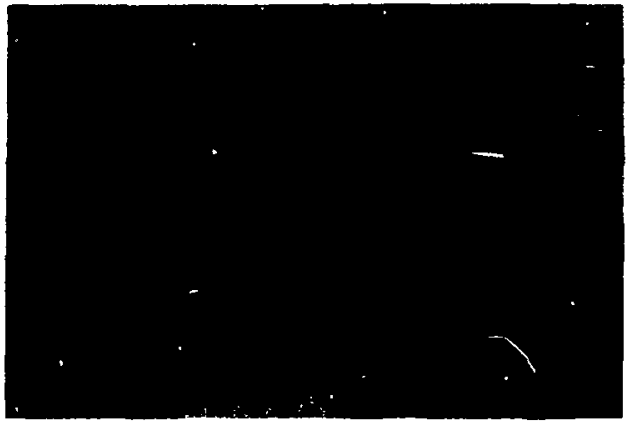

$0.25 \mathrm{~mm}$

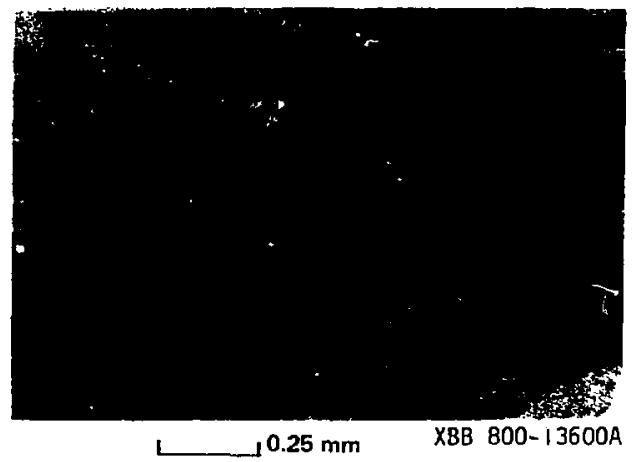

Fig. 9. Displaced twin lamellae in plagioclase grains, in fractured and brecciated quartz monzonite. Lamellae are displaced along cracks in (A) (S-29), while in (B) (S-33), lamellae are bent as well as fractured. Grain in (B) is partly altered to sericite. Crosspolarized light. 
by fracture-filling minerals. Such fractures are generally dominated by carbonate (e.g., 5-47) or, more frequent $7 y$, by chlorile. Chlorite occurs alone or in a densely intergrown mosaic wich quartz or sericite. Lenses rich in epidote or opaque materials are sometimes present (S-43, S-47), and pyrite may be locally abundant $(S-28)$. Often, wide fractures are foliated due to alignment of lenses of various materials. Foliation is also accentuated by parallel orientation of fine veins within the fracture zones (Fig. 10). Where breccia is a component of the fracture-filling, it sometimes develops the texture of mytonite gneiss (S-33, S-42).

In addition to the coarse breccias common in wide fracture zones,finegrained breccias, visible orly in thin section, are abundant in the quartz monzonite. These have bee termed "microbreccia" and consist of a tight mosaic of broken angular quartz and feldspar grains, with very sparse, generally chloritic interstitial fillings. They often form where two or more fractures converge to become one wider fracture, or where fine fractures become so pervasive that the matrix is no longer distinguishable. Microbreccia also occurs in discrete veins and in Tenses in wider fractures.

\subsubsection{Fracture Sequences}

The sequence of fo mation of the various types of fractures is generally uncertain on the basis of petrographic interpretation alone. However, for the fine, discontinuous stringers of quartz, feldspar, sericite, or chlorite discussed above, the evidence suggests that these fractures belong to an early stage of deformation. Also, fractures dominated by carbonate sometimes cut across and offset fractures filled with other materials (a relationship seen also in leptites) and carbonate also occurs as a last in-filling of coarse 


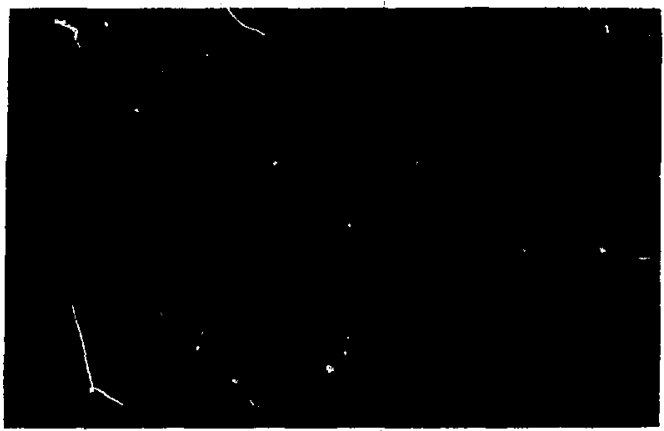

$0.5 \mathrm{~mm}$

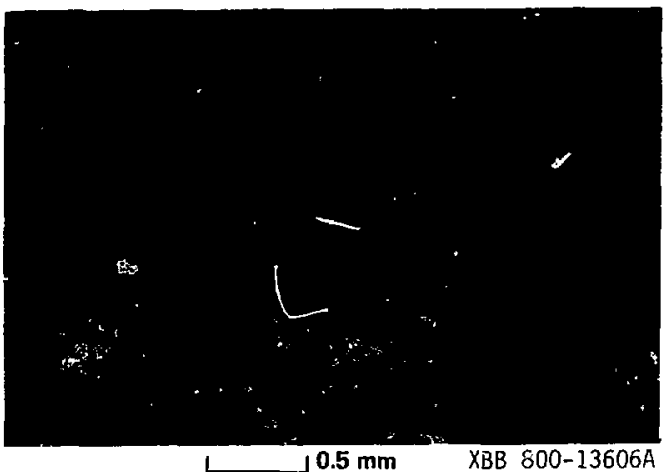

2

Fig. 10. Mylonitic breccia in contact zone between quartz monzonite and dike, S-33. Strong foliation is defined by layers of fine recrystallized quartz (q), and by stringers of sericite and chiorite (sc) running through the breccia or bordering fragments of parent granitic rock. Foliation is convoluted in (A) adjacent to the granitic augen (a), and is parallel in (B). Very finely granulated granitic rock occurs in dense aggregates $(\mathrm{g})$ and in interstices between larger fragments. Fracture filled with carbonate mineral (ca) cuts across foliation in (B). Cross-polarized jight. 
fractures. Thus it is likely that carbonate desposition belongs to the latest stage of fracturing. Fractures filled with other materials do not show a similar consistent pattern, and their formation may have spanned a wide period in the fracture history of the quartz monzonite.

\subsubsection{Open Fractures}

Open fractures, although not abundant, have been observed in some samples. They are generally about $0.05 \mathrm{~mm}$ wide, and rarely reach $0.2 \mathrm{~mm}$ (e.g. 5-41). Most often they are found within wide fractures filled mainly with carbonate, chlorite, or epidote, but they also occur within finer fractures, or along contacts between qua, $t z$ monzonite and leptite (5-10).

\subsubsection{X-Ray Diffraction Analyses of Fracture-Filling Minerals}

X-ray diffraction analyses of fractures containing epidote, chlorite, fluorite, pyrite, muscovite (sericite), quartz, and feldspars in samples from an ultra-large core recovered from the $360 \mathrm{~m}$ level were obtained (Thorpe et al., 1980). Tables 3 and 4 are diffraction patterns frois these analyses, indexed to specific minerals. Patterns were made with a Debye-Scherrer powder camera, $\mathrm{Cu} \mathrm{K}_{\alpha}$ radiation, and $\mathrm{Ni}$ filter.

In order tic index these pitterns to prominent c'-spacings of the specific minerals, separates enriched in various matrix and fiacture-filling minerais were analyzed first. This was necessary because significant variations in d-spacings and relative peak strengths occur in severa! minerals in response to variations in chemical composition. Samples thus analyzed included separates enriched in quartz, feldspars, and muscovite (i.e., chlorite 
Table 3. X-ray diffraction peaks of whole fracture-filling from ultra-large core from the $360 \mathrm{~m}$ level (Thorpe and others, 1980). a

\begin{tabular}{|c|c|c|c|}
\hline Strengthb & $2 \theta$ (degrees) & d $(A)$ & d-spacings of minerals $\langle A\rangle$ \\
\hline$m-s$ & $8.87-8.90$ & $9.94-9.98$ & Muscovite 9.95 \\
\hline$n 1-5$ & $12.50-12.53$ & $7.07-7.08$ & Chlorite $7.05-7.08$ \\
\hline$w$ & $19.75-19.85$ & $4.473-4.495$ & Muscovite $4.47-4.48$ \\
\hline$m-s$ & $20.83-20.90$ & $4.250-4.264$ & Quartz 4.26 \\
\hline$w$ & $22.10-22.13$ & $4.018-4.022$ & Plagioclase 4.03 \\
\hline 5 & $26.63-26.70$ & $3.339-3.347$ & Quartz 3.343 \\
\hline$k_{i}-m$ & $22.75-27.80$ & $3.209 \cdot 3.215$ & $\begin{array}{l}\text { Plagioclase } 3.20 \text { or } \\
\text { Muscovite } 3.20\end{array}$ \\
\hline$w \sim 7 \mid$ & 26.68 & 3.178 & Plagioclase 3.18 \\
\hline$w$ & $\therefore 0.3 i-38.33$ & $3.148-3.153$ & $\begin{array}{l}\text { Fluor ite } 3.153 \text { or } \\
\text { Plagioclase } 3.15\end{array}$ \\
\hline$n \rightarrow 11$ & $34.901-34.95$ & $2.567-2.571$ & Muscovite $2.56-2.57$ \\
\hline (1): & i5. $53-36.53$ & $2.456-2.460$ & Quartz 2.458 \\
\hline$\pi$ & 39.53 & 2.280 & Quarti 2.282 \\
\hline 16 & $+1.43-L_{i} C .48$ & $2.128-2.130$ & Quartz 2.128 \\
\hline$n:$ & $4: .0 ; 1-4 i .05$ & $1.930-1.933$ & Fluorite 1.931 \\
\hline$\because 1$ & $\therefore \quad$ is. 50.78 & $1.818-1.819$ & Quartz 1.817 \\
\hline$\therefore-i$ & $\because 4.91$ & 1.672 & Quartz 1.672 \\
\hline$\alpha-m$ & $\therefore 74-53.61 j$ & $1.647-1.648$ & Fluor ite 1.647 \\
\hline jum & $39.95-60.00 j$ & $1.542-1.543$ & Quartz i.541 \\
\hline irl & $\dot{r}=10-67.78$ & $1.383-1.384$ & Pesartz 1.382 \\
\hline ; & bu. $18-68.20$ & 1.375 & Quartz 1.375 \\
\hline
\end{tabular}

Jominant minerals are quartz, muscovite (sericite), plagioclase, and flourite. Sonk inloitce also present. (Composite of 2 readings).

bueaks are designated strong $(s)$, medium $(m)$, or weak $(w)$, is qualitative estimates of line densities in the $k-r$ ay photographs. The weakest peaks are not. i isted. 
Table 4. X-ray diffraction peaks of chlorite-enriched separate from a thick fracture in the east end of the extensometer drift.

\begin{tabular}{|c|c|c|c|c|}
\hline Strength & $2 \theta$ (degrees) & d (A) & \multicolumn{2}{|c|}{$\begin{array}{l}d \text {-spacings of } \\
\text { of chlorites }\end{array}$} \\
\hline$m-5$ & $6.33-6.40$ & $13.8-13.9$ & $\begin{array}{l}\text { (a) } \\
\text { (b) }\end{array}$ & $\begin{array}{l}14.1 \\
14.0\end{array}$ \\
\hline s & $12.50-12.53$ & $7.06-7.09$ & $\begin{array}{l}(a) \\
(b)\end{array}$ & $\begin{array}{l}7.05 \\
7.08\end{array}$ \\
\hline$w$ & $18.93-18.95$ & $4.683-4.688$ & $\begin{array}{l}\text { (a) } \\
\text { (b) }\end{array}$ & $\begin{array}{l}4.67 \\
4.681\end{array}$ \\
\hline s & $25.33-25.35$ & $3.513-3.516$ & $\begin{array}{l}\text { (a) } \\
\text { (b) }\end{array}$ & $\begin{array}{l}3.52 \\
3.523\end{array}$ \\
\hline$m$ & $34.30-34.38$ & $2.609-2.614$ & $\begin{array}{l}(a) \\
(b)\end{array}$ & $\begin{array}{l}2.601 \\
2.619\end{array}$ \\
\hline m & $34.88-34.98$ & $2.565-2.572$ & $\begin{array}{l}\text { (a) } \\
\text { (b) }\end{array}$ & $\begin{array}{l}2.554 \\
2.574\end{array}$ \\
\hline$m$ & $36.48-36.53$ & $2.460-2.463$ & $\begin{array}{l}(a) \\
(b)\end{array}$ & $\begin{array}{l}2.454 \\
2.469\end{array}$ \\
\hline$m$ & $37.43-37.53$ & $2.397-2.403$ & $\begin{array}{l}\text { (a) } \\
\text { (b) }\end{array}$ & $\begin{array}{l}2.392 \\
2.405\end{array}$ \\
\hline $\mathrm{m}$ & $39.58-39.63$ & $2.274-2.277$ & $\begin{array}{l}\text { (a) } \\
\text { (b) }\end{array}$ & $\begin{array}{l}2.266 \\
2.279\end{array}$ \\
\hline$m-5$ & $45.00-45.05$ & $2.012-2.014$ & $\begin{array}{l}\text { (a) } \\
\text { (b) }\end{array}$ & $\begin{array}{l}2.009 \\
2.074\end{array}$ \\
\hline$w$ & $48.10-48,15$ & $1.890-1.892$ & $\begin{array}{l}\text { (a) } \\
\text { (b) }\end{array}$ & $\begin{array}{l}1.882 \\
1.893\end{array}$ \\
\hline s & $59.23-59.28$ & $1.559-1.560$ & (a) & $\begin{array}{l}1.551 \\
1.560\end{array}$ \\
\hline$W$ & 60.83 & 1.523 & $\begin{array}{l}\text { (a) } \\
\text { (b) }\end{array}$ & $\begin{array}{l}1.513 \\
1.523\end{array}$ \\
\hline
\end{tabular}

ahe letters (a) and (b) designate two varieties of chlorite that have d-spacings closest to those of Stripa chlorite: (a) thuringite, with somewhat lower d-spacings; (b) bavalite, with somewhat higher d-spacings. Both these chlorites are somewhat richer in $\mathrm{Fe}$, and poorer in $\mathrm{Mg}$, than the Stripa chlorite as given in Table 2. Their diffraction patterns and chemical anaiyses are taken from the Powder Diffraction File of the American Society for Testing and Materials, 7-166 (bavalite) and cl-1227 (thuringite). 
separated out), one separate enriched in epidote, and another enriched in pyrite.

Samples were prepared for diffraction by grinding, washing, and sieving for the 230-320 mesh (62 $\mu \mathrm{m}-44 \mu \mathrm{m})$ fraction. Mineral separates were then obtained by heavy liquid separation in bromoform and/or by use of the frantz isodynamis, rilagnetic separator.

Ine errow in reading for diffraction films $(\Delta 2 \theta)$ is less than $0.1^{\circ}$. This coriesponds to decreasing errors in $d$-spacing $(\Delta d)$ with increasing 20 (or decreasing d), as follows:

$\begin{array}{ll}14.0 \% & \frac{\Delta d}{0} \text { (corresponding to } 0.3^{\circ} \Delta 2 \theta \text { ) } \\ 10.0 & 0.22 \AA \\ 1.0 & 0.11 \\ 3.0 & 0.05 \\ 15 & 0.01 \\ 1.002\end{array}$

Chin-ite anaiyzed by diffraction in Table 4 is irom a wide fracture, and nut floril aile ation of biotite, as was the chlorite analyzed by microprobe in Tab? ? ? it. i, lincertain whether these are the same or different sjecies of chlorite.

Flucrita, wlithe coarse-grained and a major fracture-filling mineral, is generally cles to pale lavender in thin section. Cften it is stained a deeper purple dround cracks or opaque grains. 
The definitive diffraction peaks used to identify epidote--those peaks not possibly due $: j$ other frature-filling minerals--correspond to $d=2.90 \mathrm{~B}$. and $d=2.68 \AA$. As coarse-grained prisms, epidote is eas ily ident if $i$ able; in thin section, it takes several forms. Often it has low birefringence cild other properties that suggest it may be clinozoisite. In many fractures ant breccias, epidote is very fine-grained and altered parially or completely to a diffuse, nearly opaque material probably rich in clay. This material is inferred to be epidote by its occasional birefringence, and by its occurrence as an alteration product on edges of otherwise fresh epidote prisms. (Sphene may, in some cases, also be a component of this material\}.

\subsection{Textur: of the Stripa Quartz Monzonite}

Several texiural features of the Stripa quartz monzonite are distinctive. One is the abundance of fractures, both continuous and discont iriuives: on a microscopic scale. Even in relatively unfractured samples, fine discontinuous cracks within primary grains or along grain boundaries are very commen. These cracks, which are filled with intergrown chlorite and sericite (or muscovite) (Fig. 7), or somet imes quartz and feldspars, suggest severa! possible interpretations. In some cases they are probably original features of a late stage of primary crysta?lization, intersti:ial to earlier formad crystals. But in most cases they are secondary, formed either in the solidified but still cooling quartz monzonite by deuteric or hydrothermal alteration, or much later as a result of heating and deformation unreldted to cooling and crystallization of the plution. Even in this last case, it is likely that the crack fillings did not crystallize from fluids introduced from extraneous sources, but are due rather to remobilization and redeposition of primary components of the rock matrix. This is suggested by the fact that the 
cracks frequently originate among primary grains of the same minerals as those filling the cracks.

This interpretation may be applied to the wider, continuous fractures in the quartz monzonite as well as to the fine, discontinuous cracks. Since the dominant mineralogy of the fracture fillings in general does not differ much from the mineralogy of the alteration products of the primary granitic matrix, it is likely that fractures (with the possible exception of those doninated by carbonate mine:als or fluorite) were filled largely as a result of remobilization and recrystallization of primary components. This is of cuurse true as well of frortures that include breccia or microbreccia, where fragments in the brecrias are clearly derivei from the parent granit ic rock.

Ancthe ystinctive feature of the Stripa quartz monzonite is the abundance of $c a t a c l a s t i c$ textures, resulting from mechanical deformation. (it shouli in wed, however, that fractured and breciciated core was choseti preferentiall: for th in sections, so thut the deseriptions in Appendix $A$ give an taxglerated impression of the abundance of deformation textures.) Kinked cleavagis planes in mica and bent twin tamellae in plagioclase (Fig. 9) are combin, and where fracturing is intense these textures give way to granulation ati corsequent brecciation. Often there is evidence of movenent along fractian surfaces or brecria zones. Slickensides are visible on many chloritic open fractures, and some thick iractures are filled with a microscopically ir - olvable ciay-rich fault gouge enclasing rounded fragments of granitic ruck. Also, mylonitic : xtures, characterized by a foliated groundmass of very finely granulated fragments enclosing scattered al igned augen of 
parent rock, occur locally (Fig. 10). These represent an extreme of cataclastic deformation and are rare in the quartz monzonite, present only when adjacent to some dikes or contacts.

\subsection{Other Granitic Rocks in the Stripa Region}

Outcrops from neighboring granitic plutons--the Gusselby, Dammsjön, and Kloten massifs--have been sampled and studied in relation to the Stripa quartz morzonite. Both texturally and mineralogically these rocks show significant differences from the rock at Stripa. The mineralogy of these plutonic rocks differs from that of the Stripa quartz monzonite in the following respects: there is little or no muscovite; biotite is often abundant, and in most cases chloritization is partial or lackina; hornblende or sphene are of ten present, and somet imes abundant; apatite is present, as is coarse-grained zircon, and qarnet is much rarer than in the Stripa rock, or absent. These differences are apparent in Table 1, showing modal analyses of selected Stripa and other granitic rocks. In Fig. 6 , where the same results are plotted in terms of relative abundances of quartz, plaqioclase, and microciline, these differences are obscured tecause the results of the Stripa analyses largely overlap those of the other rocks. However, tne differences show up more clearly in comparisons of chemical composition (discussed in the following section).

Neighboring granitic rocks differ texturally from Stripa auartz monzonite in that they are generally coarser-grained, of ten with larne poikilitic microcline, and they are much less pervasively fractured. In general they do not have the fine discont inuous cracks filled with sericite and chlorite, quartz or feldspar characteristic of the Stripa rock. However, the samples from the 
Gusselby massif, and two fine-grained light granitic rocks, $J 75-14$ and

C 75-9, from the Dammsjön and Kloten massifs, respectively, resemble, texturally, the Stripa quartz monzonite.

\subsection{Chemical Compositions and Ages of the Granitic Rocks}

Three samples of Stripa quartz monzonite, and two samples of neighboring granitic rocks, were analyzed at LBL for major element abundances by $x$-ray fluorescence. The results are shown in Table 5. The silica content of the Stripa rocks defines them as quartz monzonites rather than "granite" in the strict sense. Table 6 shows analyses of variuus samples of neighboring granitic rocks, determined by the Geological Survey of Sweden (I. Lundström, private communication). These rocks span a range from true granite (the relativeiy high silica rocks) through quartz monzonite, to granodiorite with relatively low silica contents. These analyses, as well as an average of nine analyses of Stripa fidartz monzonite determined previously (0lkiewicz et a1., 1979) have been computed to normative abundances, and plotted an a three-cumponent diagram of normative quar $c 2$, plagioclase, and $K$-feldsoar (Fig. 11). In this plot, as in Fig. 6, the fields of Stripa ani neighboring granitic rocks overlap, and they are not readily distinquishable. In Fig. 12, however, where relative oxide abundances of alkalis, $\mathrm{Fe}$, and $\mathrm{Mg}$ are plotted, the Stripa rocks cluster near the alkali corner, reflecting their paucity of mafic minerals. (One sample from the Gusselby massir, J 75-l, overlaps the Stripa field, while a second analys is from that outcrop is much richer in $\mathrm{Fe}$. This discrepancy, as well as others in these analyses, may be due to heterogeneity of the sampled outcrops). 
Table 5. X-ray fluorescence major-element andlysis of relatively fracture-free granitas from Stripa and neighboring plutons.

\begin{tabular}{|c|c|c|c|c|c|}
\hline \multirow[b]{2}{*}{ Oxides } & \multicolumn{3}{|c|}{ Stripo Quartz Monzonite } & \multirow{2}{*}{$\begin{array}{l}\text { Gusseloy Massif } \\
\text { J 75-1 }\end{array}$} & \multirow{2}{*}{ Kloten Hass if } \\
\hline & $E 7-2^{d}$ & $5-12$ & $5-38$ & & \\
\hline $\mathrm{SiO}_{2}$ & $73.83 \pm 1.48$ & $14.73=1.49$ & $74.37 \div 1.49$ & $72.29 \div 1.45$ & $67.60 \pm 1.35$ \\
\hline $\mathrm{TiO}_{2}$ & $\sim 0.3 \pm 0.2$ & $-0.03: 0.2$ & $\sim 0.06 \pm 0.2$ & $\sim 0.4+0.2$ & $\sim 0.6 \pm 0.2$ \\
\hline $\mathrm{Al}_{2} \mathrm{O}_{3}$ & $14.24 \pm 0 . \angle 8$ & $13.91 \div 0.28$ & $14.12+0.28$ & $13.64 \pm 0.27$ & $13.87 \pm 0.28$ \\
\hline $\mathrm{Fe}_{2} \mathrm{O}_{3}^{\mathrm{D}}$ & $1.07 \pm 0.02$ & $1.20 \div 0.02$ & $0.92: 0.02$ & $2.93 \div 0.06$ & $5.89 \pm 0.12$ \\
\hline Mno & $\sim 0.03 \pm 0.02$ & $\sim 0.04 \pm 0.02$ & $-0.03 \pm 0.02$ & $\sim 0.07 \pm 0.02$ & $\sim 0.14 \pm 0.02$ \\
\hline $\mathrm{Cr}_{2} \mathrm{O}_{3}$ & $<0.05$ & $<0.05$ & $: 0.05$ & $<0.05$ & $<0.05$ \\
\hline$M g O$ & $-0.2=0.7$ & $\sim 0.2 \pm 0.7$ & $-0.3 \pm 0.7$ & $\sim 0.4 \pm 0.7$ & $\sim 0.7 \pm 0.7$ \\
\hline $\mathrm{CaO}$ & $0.85 \div 0.112$ & $0.81 \pm 0.02$ & $0.79=0.02$ & $1.30 \pm 0.03$ & $2.42 \pm 0.05$ \\
\hline $\mathrm{Ha}_{2} \mathrm{O}$ & $4.14 \pm 2.1$ & $3.51 \div 1.8$ & $4.13+2.1$ & $3.39 \pm 0.17$ & $3.26 \pm 0.16$ \\
\hline $\mathrm{K}_{2} \mathrm{O}$ & $4.65 \div 0.09$ & $4.90 \div 0.10$ & $4.29 \times 0.09$ & $5.22 \pm 0.10$ & $4.84 \pm 0.10$ \\
\hline Total & 99.0 & 99.3 & 99.0 & 99.7 & 99.3 \\
\hline
\end{tabular}

Average of two analyses. This sample is from an extensometer hole drilled from full-scale drift.

bTotal Fe as $\mathrm{Fe}_{2} \mathrm{O}_{3}$. Oxidation siate of $\mathrm{Fe}$ unknown.

These who'e rock chemical andyses were obtained at LBL on a inultiple anode soft $x$-ray fluorescence spectrometer (Hebtrt and street, 1973). The sample was tirst jround to d ine powder, then fused with a bi80 2 flux and poured to form a glass oisc.

Errors :-t computed as $2 x$ of reported values for rildtively abuodant oxtdes, except for Hazo for which a $5 \%$ error is uses. This corresponds roughly to ane standard devidion. For oxides of very low abundance, values are more approx imate. 


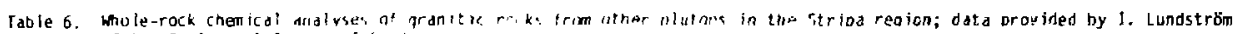
of the Geological Sitrvey of imeden.

\begin{tabular}{|c|c|c|c|c|c|c|c|c|c|c|c|c|c|}
\hline Oxide & C & $\begin{array}{c}{[75: 10} \\
x\end{array}$ & $\begin{array}{r}c 75: 1^{1} \\
\times\end{array}$ & $\begin{array}{c}\text { koter } \\
115: 10\end{array}$ & 175:11 & $\begin{array}{r}{[75: 78} \\
t\end{array}$ & $\begin{array}{c}1679: 1 \\
175: 16 \\
x\end{array}$ & $\begin{array}{c}\text { Ensse } \\
\text { J74:1 } \\
x\end{array}$ & $\begin{array}{r}\text { Mass if } \\
\text { J75: } \\
x\end{array}$ & $\begin{array}{c}.175: 4 \\
x\end{array}$ & $\begin{array}{c}\text { Darm } \\
\times 5: 7^{2}\end{array}$ & $\begin{array}{c}\text { on Mass if } \\
\text { J75:8 } \\
x\end{array}$ & $\begin{array}{c}375: 9 \\
\times\end{array}$ \\
\hline $\mathrm{SiO}_{2}$ & 76.1 & 74. & 12.6 & 75.7 & 69.8 & 74.0 & 77.8 & 71.5 & 74.1 & 71.3 & 72.3 & 70.0 & 71.9 \\
\hline $\mathrm{TiO}_{2}$ & 0.11 & 0.30 & 0.44 & 0.13 & 0.73 & 0.34 & 0.08 & 0.36 & 0.03 & 0.58 & 0.37 & 0.63 & 0.53 \\
\hline $\mathrm{Al}_{2} \mathrm{O}_{3}$ & 12.9 & 33.0 & 13.0 & 12.9 & 13.6 & 13.3 & 13.0 & 13.8 & 14.2 & 13.4 & 13.1 & 13.6 & 13.1 \\
\hline $\mathrm{Fe}_{2} \mathrm{O}_{3}$ & 1.4 & $3 . ?$ & 4.0 & 2.0 & 5.8 & 3.4 & 1.2 & 2.4 & 0.9 & 4.3 & 3.5 & 4.9 & 4.8 \\
\hline $\sin 0$ & 0.01 & 0.04 & 0.05 & ל. & 0.04 & 0.05 & 0.02 & 0.04 & 0.03 & 0.08 & 0.06 & 0.09 & 0.07 \\
\hline $\mathrm{MgO}$ & 0.20 & 0.17 & $0 . \angle B$ & 0.39 & 0.76 & 0.32 & 0.19 & $0 .{ }^{\circ}$ & 0.09 & 0.62 & 0.32 & 0.68 & 0.49 \\
\hline $\mathrm{CaO}$ & 0.6 & 1.2 & 1.6 & 1.0 & 2.3 & 1.3 & 1.4 & 1.1 & 0.4 & 1.7 & 1,6 & 2.1 & 1.4 \\
\hline $\mathrm{Na}_{2} \mathrm{O}$ & 3.2 & 3.0 & 3.0 & 3.5 & 2.9 & $3 . ?$ & 3.8 & 3.2 & 4.2 & 3.3 & 3.5 & 3.4 & 3.1 \\
\hline $\mathrm{K}_{2} \mathrm{O}$ & 5.2 & 5.2 & 5.3 & 4.6 & 4.8 & 5.0 & 3.4 & 5.6 & 5.6 & 4.7 & 4.7 & 4.4 & 4.7 \\
\hline
\end{tabular}




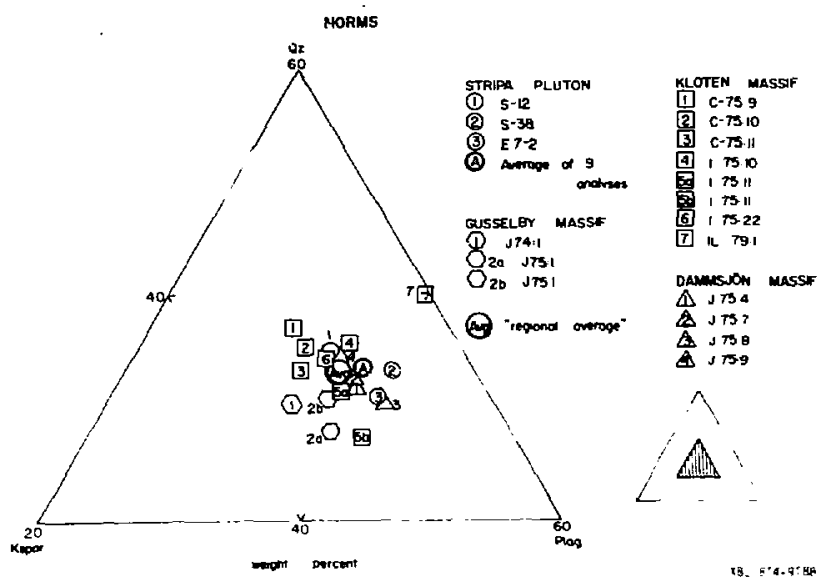

Fig. 11. Relative normative abundances of quartz, plagioclase, and K-feldspar (normalized to 100:) in analyses listed in Tables 5 and 6 , and in nine analyses of Stripa quartz monzonite by A. OIkiewicz et al. (1978). 


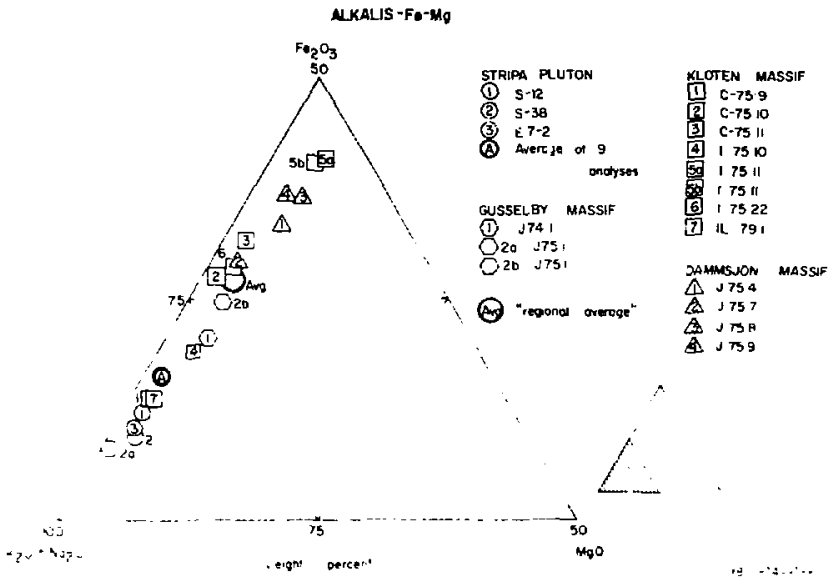

Fi. i. Felative abundances of oxides of Fe, $\mathrm{Mg}$, and aikalis (normalized to $100^{\circ}$ ), in samples in Fig. 11 . 
Radiometric dates for one sample of Stripa quartz monzonite (S-38) and two of neighboring granitic rocks, $J$ 75-1 (Gusselby massif) and I 75-11 (Kloten massif), were determined by potassium-argon dating at the University of California, Berkeley, by G. Curt is and R. Orake. For the Stripa sample, a muscovite separate was used; for the others, biotite separates. The samples showed little or no alteration of the mica minerals, and the coarse sieve fraction of the separates should have excluded most secondary fine mica grains filling fractures or discont inuous cracks.

The dates obtained in these analyses were, in millions of years, $1691 \pm 16,1604 \pm 14$, and $1640 \pm 44$ for $5-38, J 75-1$, and $I 75-11$, respectively (Table 7 ). As muscovite has a slightly higher argon retentivity than biotite, the gap between the oldest (muscovite) date and the youngest date would be smaller than these figures indicate. Despite precautions taken to ensure that the separates were free of micas of clearly secondary origin, there is no assurance that these dates represent the true ages of primary crystallization and original argon retention or that they were not reset by a later thermal event.

For comparison, Welin et al. (1980) reported older K-Ar ages of muscovite (1712 to 1826 m.y.) from late kinematic stage pegmatites of the Uppsala region. Si?icic volcanic rocks in the Uppsala region have a significantly higher whole-rock Rb-5r age of 1830 m.y.

\subsection{Leptite and Associated Rocks}

Leptite is a common rock both in outcrop and in cores from Stripa. It is usually a grey-green to black, fine-grained foliated metamorphic 
Table?. Results of radiometric dating of gi anisic sampies from the Stripa region, by the potassium-argon method.

\begin{tabular}{|c|c|c|c|c|c|}
\hline Sample & $\begin{array}{l}\text { Mineral } \\
\text { An alyzed. }\end{array}$ & $40 \mathrm{Ar} *(\mathrm{pgm})^{2}$ & $40 \mathrm{Ar} * 140 \mathrm{Ar}$ Total & $K(\%)$ & Date (in $10^{6}$ years) ${ }^{b}$ \\
\hline $\mathrm{S}-38$ (Stripa) & muscovite & $4.331 \times 10^{-2}$ & 0.990 & $8.911 \pm 0.1$ & $1691 \pm 16$ \\
\hline $\begin{array}{c}\text { J5-1 (Gusselby } \\
\text { Massif) }\end{array}$ & biotite & $3.234 \times 10^{-2}$ & 0.983 & $7.214 \pm 0.1$ & $1604 \pm 14$ \\
\hline $\begin{array}{r}\text { I 75-11 (k loten } \\
\text { Massif) }\end{array}$ & biotite & $2.760 \times 10^{-2}$ & 0.312 & $5.953 \pm 0.1$ & $1640 \pm 44$ \\
\hline
\end{tabular}

a $40 \mathrm{Ar}$ * refers to radiogenic $40_{\mathrm{Ar}} ; 40 \mathrm{Ar}$ Total is the sum of radiogenic and atmospheric $40 \mathrm{Ar}$.

berror in dates depends on error in $K$ abundance, and on $r$ at io of atmospheric to radiogenic $40_{A r}$.

Constant s:

$$
\begin{aligned}
& \lambda_{B}=4.962 \times 10^{-10} / \text { year } \\
& \lambda_{e}+\lambda_{e}=0.581 \times 10^{-10} / \text { year } \\
& 40_{K / K_{\text {tot a }}}=1.167 \times 10^{-4}
\end{aligned}
$$

Muscovite and biotite separates used for these analyses were obtained by crushing, sieving for the 28-60 mesh fraction (295 - $589 \mathrm{~mm})$, and separation by the Frantz isodynamic magnat ic separator.

Analyses by R, Or ake and G. Curtis, and potassium analyses by $f l$ ame photametry by J. Hampel, of the Department of Geolocy and Geophysics, University of Cal if ornia, Berkeley. 
rock (microschist) often cut by wite or light green fractures. Mineralogically it is similar to the Stripa quartz monzonite; it is composed mainiy of quartz, plagioclase, microcline, chloritized biotite, and muscovite. But texturally, it does not resemble most of the granit ic rocks, as it is much finer, more even-qrained, and homogeneous (Fig. 13).

In detail, leptites generally consist of a fine, even-grained mosaic of equant quartz grains with fewer plagioclase and microcline grains. Parallel, elongate laths of chlorite and muscovite define the foliation. Sub-equant quartz porphyroblasts*, typically up to $1-2 \mathrm{~mm}$ in diameter, are common (Fig. 13). Darker leptites generally contain more chlorite, at the expense of muscovite, than the lighter leptites, or they conta in fewer porphyroblasts. As in the Stripa quartz monzonite, chlorite has generally replaced biotite complecely, but in a few cases some biotite remains intergrown. Pleochroic halos are common with in chlorite and may contain discrete opaque grains or, rarely, birefringent high-relief grains, probably zircon (e.g., ST-27). Muscovite, like chlorite, generally occurs in narrow laths, but coarser muscovite also occurs and is generally sieve-textured.

Fractures are abundant in the leptite, and fracture-fill mineralogy is similar to that in the quartz monzonite. Epidote, however, appears to be more abundant in the leptite than in the quartz monzonite, commonly filling light green sinuous fractures up to $1 \mathrm{~cm}$ wide. Coarse prisms of epidote are the sole constituents of some fractures, while in others epidote is intergrown with quartz, with sericite and chlorite, or with carbonate \#The term "porphyroblast" is intended here in a descriptive sense only. Regarding the origin of the porphyroblasts, the consensus among Swedish geologists is that they are relict phenocrysts, and that the leptites are metamorphosed volcanic and volcanistic rocks (0lkiewicz et al., 1979; Geijer and Magnusson, 1944). 


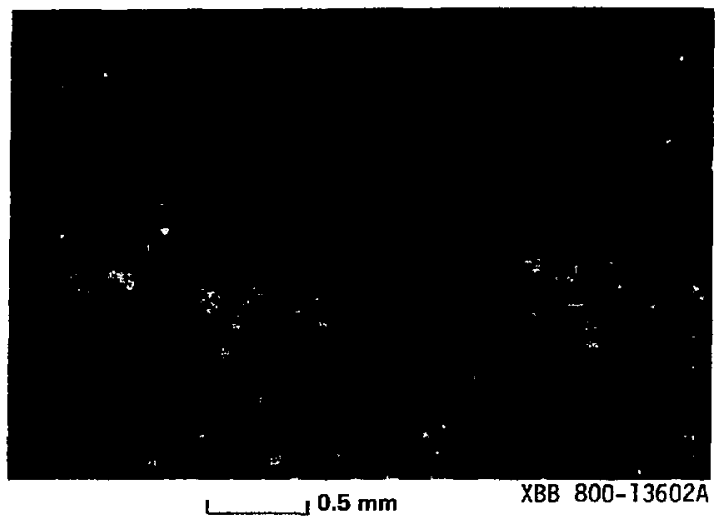

Fig. 13. Fine-grained foliated leptite, ST-1. Foliation (diagonal from upper left) is defined by narrow laths of muscovite and lesser chlorite, set in an even-grained mosaic of quartz, microcline, and plagioclase. Small quartz porphyroblasts $(q)$ are present. Cross-polarized light. 
minerals and fluorite. Epidote also occurs in isolated patches in leptite, and in some cases as prisms aligned parallel to the foliation. Quartz-filled or quartz-carbonate-filled fractures are also abundant, and in several thin sections may be seen to cut and off set epidote veins (Fig. 14). Chlorite occurs as a fracture-filling mineral, but much less abundantly than in the quartz monzonite. Brecciated leptite occurs in wide fracture zones (e.g., $S-6)$, with interstices between fragments filled with coarse grained fluorite, carbonate, quartz, and other minerals. Finely brecciated leptite (microbreccia) is an occasional constitiıent of wide fractures. Also, very fine intergrowths of quartz and feldspars, with lesser chlorite, sericite, and opaque materials, commonly form vein-like features in leptite. It is unclear whether these are fracture fillings or simply textural inhomogeneities with in the leptite matrix.

Leptites have been interpreted as originating from rhyolitic lavas and tuffs, possibly deposited in water (see footnote, p. 39). In the leptites studied here, textures that would indicate a volcanic protolith have generally been erased by metamorphism. They generally resemble schists derived from shale or sandy shale, thus suggest ng a volcaniclastic protolith.

Contacts of leptite with Strip $\lrcorner$ quartz monzonite have been observed in several thin sections, and these contacts are generally sharp. Thin growths of sericite, or epidote-chlorite-filled fractures, somet imes occur at the contact; in one case (S-17) uranium-bearing opaque grains are as sociated with the contact.

Contacts between quartz monzonite of typical Stripa texture and more even-grained foliated granitic rock resembling leptite were observed in 


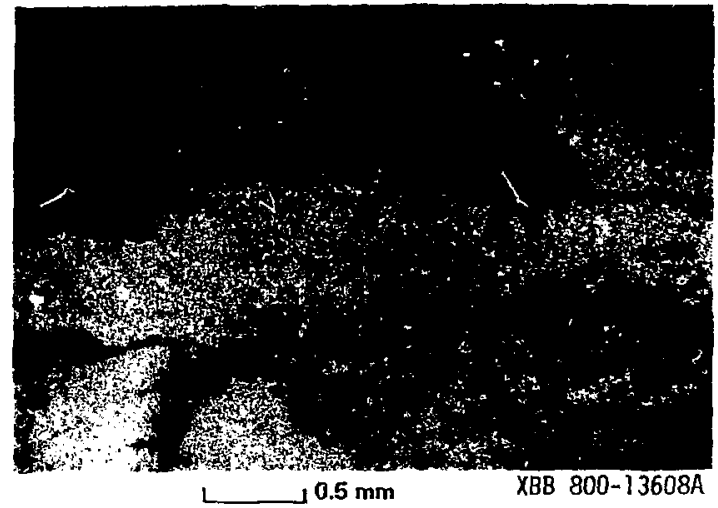

Fig. 14. Intersecting fractures in leptite, S-5. Fracture filled with quartz and carbonate mineral (horizcntal in figurel offsets wider epidote-filled fracture (diagonal from upper left). Sense of offset is left-lateral. Plane-polarized light. 
several thin sections (e.g., S-44, S-45). In one sample (S-10) a band of foliated granitic rock. I mm wide, separates quartz monzonite from thick foliatad chiorite-rich fracture zone. This thin band contains abundant chlorite grains in parallel aligrment and is essentially a leptitc; yet it is gradational from quartz monzonite of more t.vpical texture. This points up the orcasional difficulty of distinguishing foliated granitic rock from leptite in hand sample.

\subsection{Amphibolite and Diabase}

Another variety of metamorphic rock at Stripa is a dark green, finegrained foliated rock rich in blue-green frismatic amphibole, of ten logged in core descriptions as "greenstone." Texturally this amphibolite is a microschist like the more abundant leptite. However, its foliution is determined by amphibole prisms instead of chlorite and muscovite laths. Interstices between amphiboles consist of quartz, plagioclase (very altered), opaques, and carbonate. White fractures filled mainiv with carbonate and quartz, and ligh: green fractures filled mainly with epidote, are common in the amphibo1ite. Also, wide foliated fracture zones occasionally cut amphibolite (5.9), and these contain lerises of various colors and materials aligned parallel to the foliation. Carbonate is last in the sequence of these fracture-filling materials (Fig. 15). One sample of dark, mafic rock (S-14) does not have a foliated, schistose texture, but consists, instead, of much coarser, stubby amphibole grains. In hand sample it resembles an altered diorite, but can be seen in core samples to arade into the more typical amphibo? ite. 


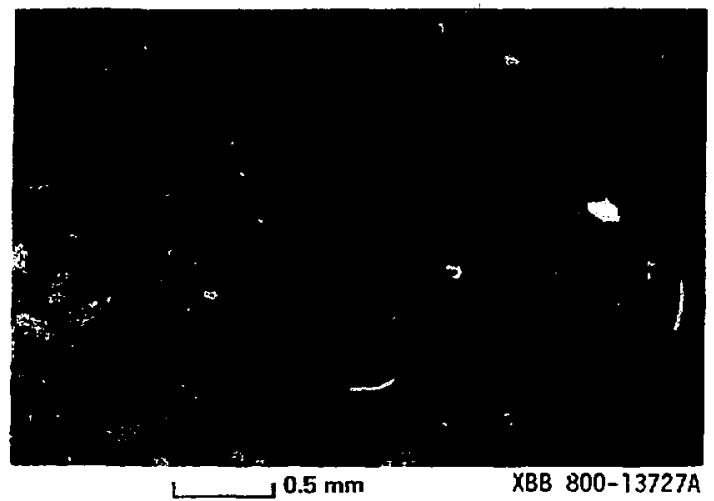

Fig. 15. Wde foliated fracture zone in amphibolite, 5-9. Lensoid cavity at upper left is lined with quartz ahedra $(q)$, and filled with carbonate mineral 1.a) deposited over the quartz. It is bordered ' $y$ bands of chlorite (c) and fine-grained car bonate. Lower right portion of figure consists of a fine breccia of fragmented quartz and feldspar Jrains with intergrown chlorite, sericite, and carbon. te, cross-polarized light. 
Some Swedish geologists have interpreted amphibolite dikes as being altered diabase (01kiewicz et al., 1979). Our observations of a limited number of amphibolite samples at Stripa neither support or reject this interpretation.

One sample of altered diabase (ST-35) was examined in thin section and is described in detail in Appendix A. It resembles a dark leptite in hand sample, but has an even more uniform grain size, and is not foliated. 


\subsection{RADIOGEOLOGY}

The abundance of radioe lements was measured, both on the surface and underground, to obtain a preliminary indication of the geochemical homogeneity of the Stripa pluton and to calculate its radiogenic heat production.

\subsection{Instrumentatiol.}

The instrument used to determine the concentrations of the radioelements --potassium, uranium and thorium--was a portable gamma-ray spec rometer (GR-410) with a scintiilation detector (GPX-21), both made by Geo-Metrics Inc. The detector consists of a 3-in. diameter by 3-in. thick thalliumactivated sodium-iodide crystal optically coipled to a high-gain photomultiplier tube that is hermetically sealed within a thermally insulated housing. The housing contains a high-voltage power supply and a preamplifier.

The $k, U$, and Th concentrations are calculated from counts accumulated by the $\gamma-r$ ay spectrometer in three pre-set intervals of the $Y-r a y$ energy spectruni, centered respectively on the $40_{\mathrm{K}}$ peak at $1.46 \mathrm{MeV}$, the $214_{\mathrm{Bi}}$ peak at $1.76 \mathrm{MeV}$, and $208 \mathrm{Tl}$ peak at $2.62 \mathrm{MeV}$. The widths of the $\mathrm{K}$ and $\mathrm{Bi}$ intervals are $200 \mathrm{keV}$, and that of the $\mathrm{Tl}$ interval is $400 \mathrm{KeV}$. As $214_{\mathrm{Bi}}$ and $208 \mathrm{Il}$ are the respective daughter products of the $238 \mathrm{U}$ and 232 In decay series, it is assumed that they are in secular equilibrium with their parents in the rocks being measured. A fourth interval, total counts, encompasses a broad portion of the $\gamma$-spectrum, from 0.5 to $5.0 \mathrm{MeV}$. 


\subsection{Field Procedures}

A total of 81 gamma-ray readings were made, at both surface and underground locations (see Figs, 1-4 for locations). All measurements were made with the detector held in contact with the rock. Three different recording times were used, depending on the counting rates observed: 20 seconds at sites of high $Y$ activity, 1 minute at sites of intermediate activity, and 2 minutes at relatively low-activity sites. The counting times were chosen to allow a statistically significant number of counts to accumulate in the lowest-radioactivity interval, that of $208 \mathrm{Tl}$. The count rates for the three radioelements, the total counts, and the measurement time were recoided. A hand specimen, for subsequent laboratory tests, was taken at almost every sample location.

\subsection{Treatment of Field Data to Yield the $K, U$ and Th Values}

Before any data were taken, the gamma-ray spectrometer was calibrated with the internal reference isotope ( $133_{\mathrm{Ba}}$ ) with a $\gamma$-ray enerqy of 0.355 MeV, using a split window and a gain adjustment potentiometer. The instrument's background count rates, measured in a low-background environment at Lawrence Livermore National Laboratory, were:

Total counts: 2004 counts/minute Potassium interval: 20.8 counts/minute Uranium interval: 26.4 counts/minute Thorium interval: 9.6 counts/minute

These numbers were then subtracted from the field readings to get a "net count rate" for each energy interval. Two different sets of equations 
were used to derive the radioelement concentrations from the count rates: one provided by the manufacturer, Geometrics Inc, based on measurements at the U.S. DOE facility at Grand Junction, Colorado, and one obtained from measurements on pads of known radioelement content at Ris $\varnothing$ National Laboratory, Denmark as follows:

(a) From the manufacturer:

$$
\begin{aligned}
& \text { Potassium }(q)=\left[C_{K_{L}}-0.68 C_{U}-0.83 C_{T h}\right] / 154 \\
& \text { Uranium }(p p m)=\left[C_{U}-0.62 C_{T h}\right] / 20.5 \\
& \text { Thor ium }(\mathrm{ppm})=C_{T h} / 7.5
\end{aligned}
$$

where $C_{K}, C_{11}$ and $C_{T h}$ are the "net count rates" in counts per minute for potassium, uranium and thorium, respectively.

(t) From Dice National Laboratory:

$$
\begin{aligned}
& \text { Pot ascum }\{y\}=\left[i_{k}-0.51 C_{1}-0.86 C_{T h}\right] / 161 \\
& \text { ranium }(\mathrm{ppm})=\left[\mathrm{C}_{11}-0.59 \mathrm{C}_{\mathrm{Th}}\right] / 15.9 \\
& \text { Thir ! gr }(\mathrm{ppm})=C_{\mathrm{Th}} / 7.0
\end{aligned}
$$

Tho differences between the two sets of equations are most likely due to the differwnt physical characteristucs of the DOE and Ris $\phi$ standards.

\section{A Ahoretery fanma Spectrometry Results}

To orovide definitive calibration for the portable Y-spectrometer data, 1. af the hand specimens were analyzed by A. Smith in the LBL low background corrting fai ility. The hand specimens were chosen from both surface and subsurface lorations and included all rock types encountered at Stripa. The wsults nf hy laboratory y spectrometry are qiven in Table 8.

After the apparent radioelement concentrations were calculated from the above equations, we attempted to obtain more nearly actual values by 
Table 8. Laboratory $\gamma$-spectral analyses of Stripa rock types.

\begin{tabular}{|c|c|c|c|c|c|}
\hline $\begin{array}{c}\text { Samplo } \\
\text { No. }\end{array}$ & $\begin{array}{c}\text { Locality } \\
\text { No. a }\end{array}$ & Description & $\begin{array}{l}U \\
\text { (ppm) }\end{array}$ & $\begin{array}{l}\text { Th } \\
\text { (ppm) }\end{array}$ & $\begin{array}{l}k \\
(x) \\
\end{array}$ \\
\hline$S T-1$ & Y7 & leptite, surface & 2.25 & 11.1 & 3.63 \\
\hline$S T-3$ & Y9 & qtz. monz., surface & 24.4 & 31.3 & 3.98 \\
\hline$S T-9$ & $Y 39$ & qtz. monz., underground & 34.2 & 32.1 & 3.97 \\
\hline ST -12 & $Y 42$ & qtz. monz., underground & 40.9 & 31.4 & 3.84 \\
\hline$S T-18$ & $120 a$ & $\begin{array}{l}\text { qtz. monz., abundant } \\
\text { chiorite, underground }\end{array}$ & 44.1 & 31.2 & 4.14 \\
\hline $57-18 a$ & $r 20 b$ & qtz. monz., underground & 42.8 & 31.3 & 3.77 \\
\hline$S T-21$ & $\gamma 32$ & qtz. monz., underground & 35.2 & 29.2 & 3.75 \\
\hline$S T-27$ & $Y 54$ & ieptite, underground & 6.10 & 17.2 & 2.72 \\
\hline$S T-32$ & $\gamma 12$ & leptite, surface & 3.63 & 11.2 & 2.15 \\
\hline ST -35 & Y34 & diabase, underground & 1.19 & 3.79 & 1.28 \\
\hline$S T-48$ & $: 63$ & $\begin{array}{l}\text { reddish granitir., } \\
\text { surface }\end{array}$ & 15.4 & 30.5 & 3.99 \\
\hline ST -23 & $\gamma 47$ & $\begin{array}{l}\text { uranium ore, } \\
\text { underground }\end{array}$ & 1320 & 22 & - \\
\hline$S \Gamma-2.3 a$ & $\Upsilon 47$ & banded $\mathrm{Fe}$ ore, underground & 0.51 & 0.35 & 0.003 \\
\hline
\end{tabular}

d Ganıma measurement locality number. 
plotting the laboratory-determined radioelement contents aga inst the field results for the same samples (from both underground and surface locations); the calibration curves are shown in Fig. 16. The slopes and intercepts of the lines were then used to correct the field readings. These corrected values are listed in Appendix $B$ and summarized in Table 9.

The callbration diagrams ( $F$ ig. 16) indicate that the slopes of the lines relat ina laboraiory analyses to surface measurements are considerably steeper than thowe relding laboratory to underground measurements. This is because the underground sites are essentially surrounded on all sides by $r$ sources (. 4 is qeurletry) in contrast to the surface where planar geometry predominates. The hlyh zero intercept on the calibration diagram for underground measurements of uranium may be attributed to the abundance of radon in the mine's air. The low background indicated in the thorium interval for undergrounc: mediurements is attributed to the attenuation of cosmic rays by the rock, resulting in a lower contribution of counts to the Th interval from highenergy cosmic rays than at the surface. Calibrations based on the Ris and DOE facilities are most applicable to the genmstry of surface measurements.

\subsection{Fission Track Radiography Results}

The fission-track radiographic method (wollenberg, 1972) was used to determine the location and abundance of uranium in uncovered thin sections. Most samples were of Stripa quartz monzonite, but also included where three leptites and several neighboring granites. 

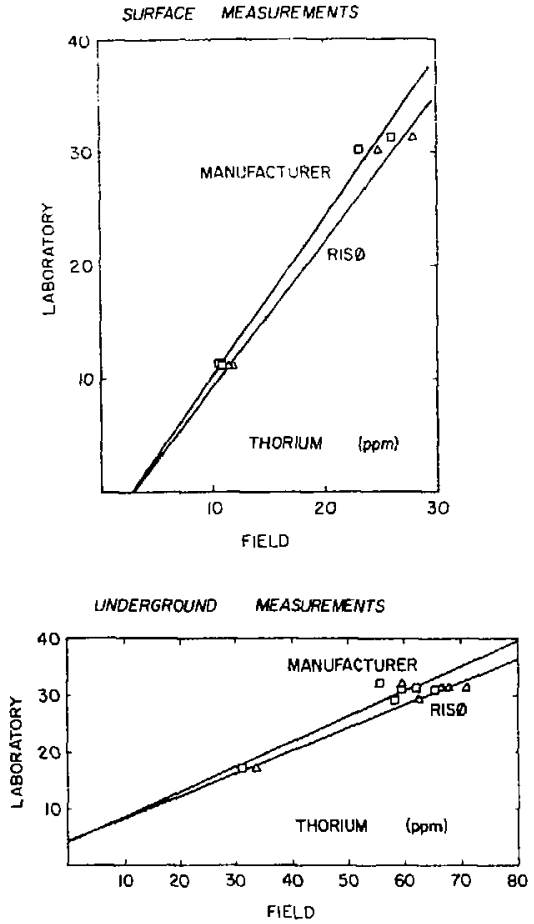
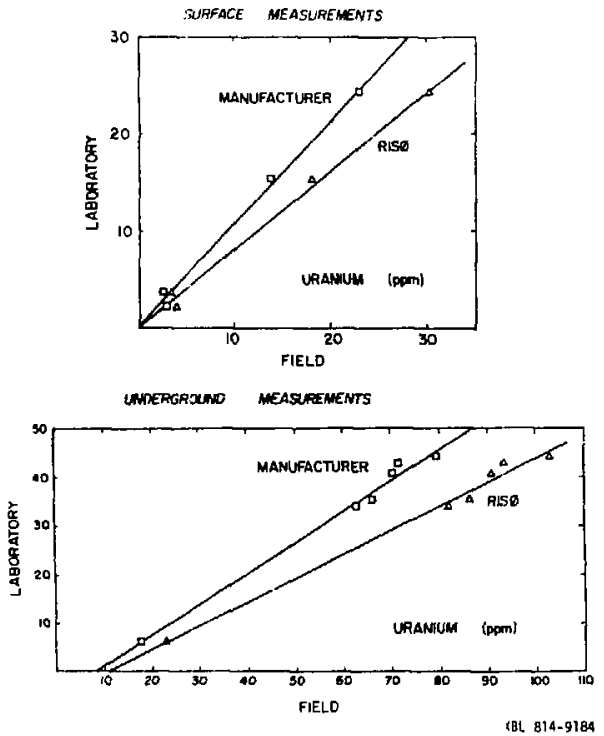

Fig. 16. Calibration curves relating ralioelement contents determined by surface and underground $\gamma$-spectral measurements to laboratory radioelement analyses. 


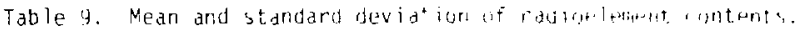

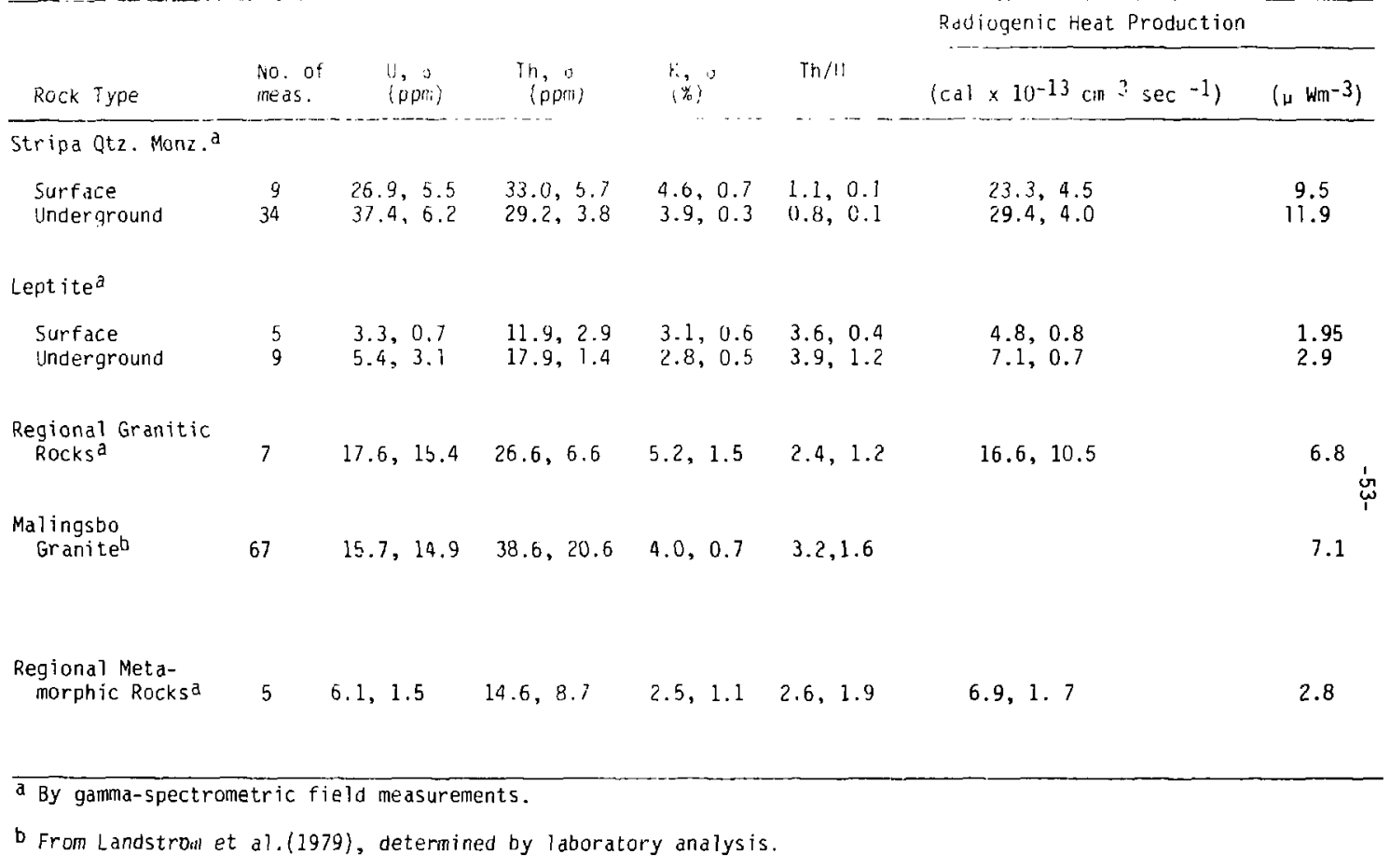


In the Stripa quartz monzonite, uranium is most highly corcentrated in tiny opaque grains about 50 mm or less in diameter, of ten euhedral, and sometimes square in cross-section. These grains are usually found in chlorite, but also in muscovite-chlorita-sericite-filled fractures, and even in cracks within quartż or feldspar (Figs. 17 and 18). The grains of ten contain up to 10-20\% $U$, but concentrations greater than $50 \% \mathrm{U}$ have been observed. In chlorite, these grains are surrounded by deep pleochroic halos, and where they occur in quartz or feldspar they occas ionally will also have dark halos around them, possibly a result of aiteration due to radiation damage. Although pleochroic halos are very abundant in chlorite grains, they are not a reliable indicator of $\mathrm{U}$ loci; in fact, they only rarely include uranium-rich opaque minerals.

Another locus of uranium concentration is in opaque grains of a different morphology and mode of occurrence. These grains are larger--from 0.2 to $0.5 \mathrm{~mm}$-and they are anhedral, often with irregular, scalloped edges, in contrast to the frequentiy euhedral opaques discussed above. Uraniferous anhedral opaques have been observed in two samples. One is a contact between quartz monzonite and leptite (\$-17); here anhedral opaques occur in a quartzepidote-sericite-filled fracture on the contact, and on fine carbonate-sericite stringers intersecting the contact on the quartz monzonite side (Fig. 19). The other sample is a network of fractures in quartz monzonite, filled with calcite and asphaltita (see discussion in Section 2.3.1); anhedral opaques are abundant in this sample, and occur both within and adjacent to the fractures. In both samples, the uraniferous opaque grains contain $\sim 1-3 \% U$. 

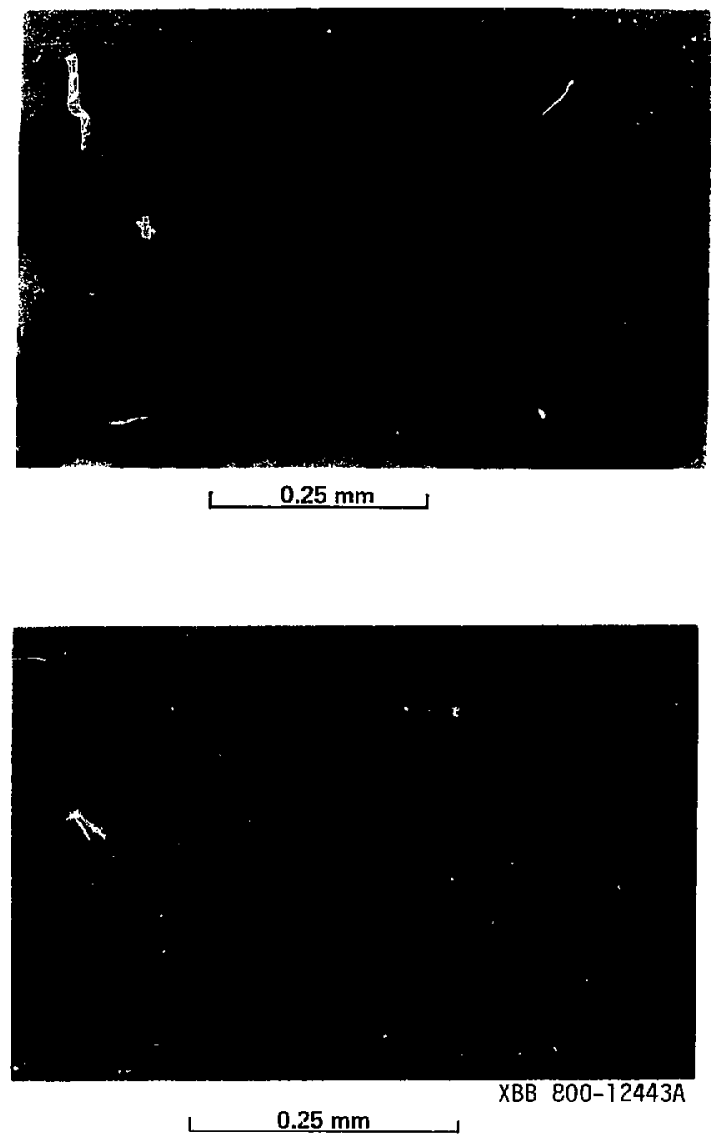

Fig. 17. Fission tracks (B) from $U$ in two fine opaque grains (o) in chlorite $(A)$, in relatively unfractured quartz monzonite, S-38. U concentration in these grains is $>50 \%$. Note several non-opaque grains ( $n$ ) which, although enclosed in pleochroic halos like the opaque grains, lack associated fission tracks. The edges of the chlorite grain also have sparse fission tracks associated. Planepolarized light. 

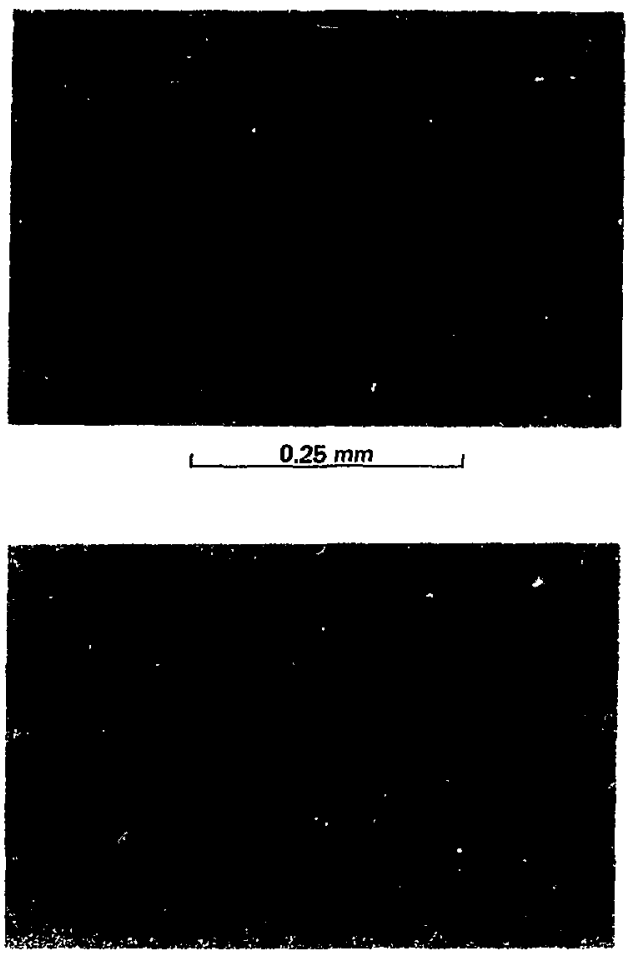

$\boldsymbol{B}$

Fig. 38. Fission tracks (B) from $U$ in euhedral opaque grain (20-30\% U), and along fine chloritefilled fractures $(0.5$ to $1 \% U$ ) in fractured and brecciated quartz monzonite, $S-29(A)$. plane-polarized light. 

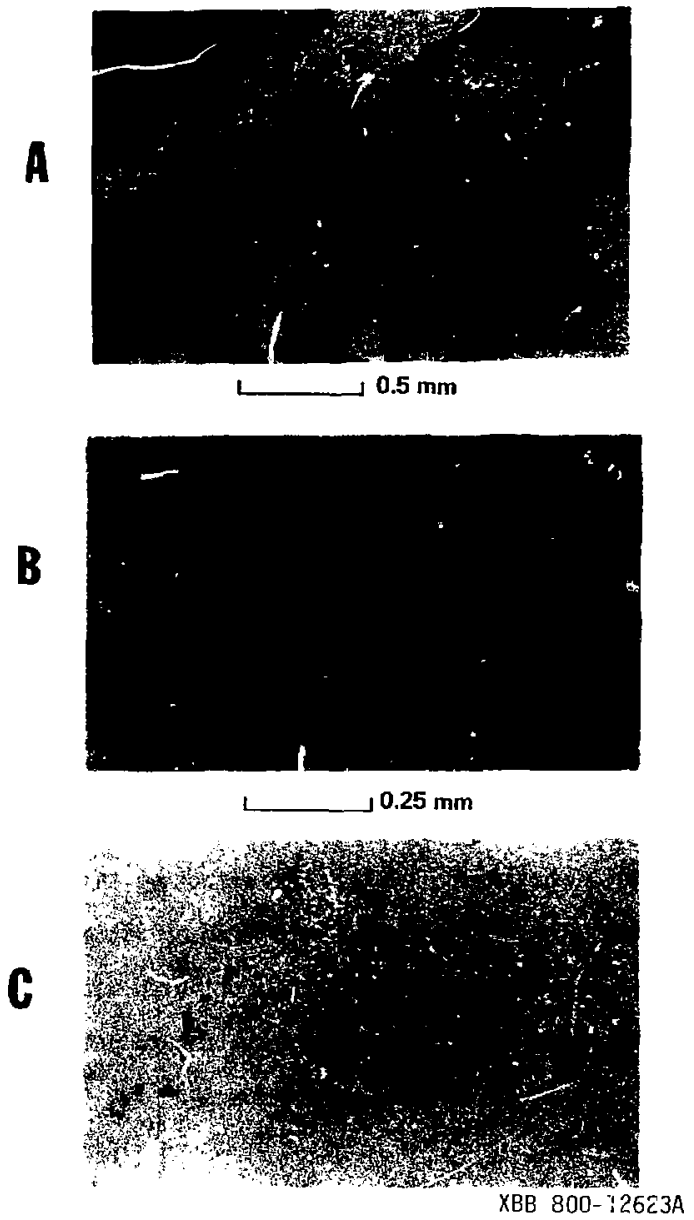

Fig. 19. (A) Anhedral opaque grain (0) on carbonate stringer (ca) in fractured granitic rock adjacent to contact with leptite, S-17. Cross-polarized light. (B) Same grain at higher magnification. (C) Fission tracks from $U(2 \%)$ in opaque grain of $(A)$ and $(B)$. Planepolarized light in (B) and (C). 
Although the concentration of $U$ is lower in these grains than in the euhedra, the absolute abundance of $U$ is greater, as they are larger in voiune by well over an order of magnitude. Proper identification of the mineralogy of the opaque grains will require detailed electron-microprobe examinations.

Uranium is also found dispersed in lower concentrations along chloritefilled fractures without associated discrete grains (Fig. 18). Concentrations are generally about $0.5 \% \mathrm{U}$ or lcwer, but occasionally range up to about $1.0 \% \mathrm{U}$. Uranium concentrations in these $\mathrm{lc} z i$ are the most like?y sources of the ${ }^{222} \mathrm{Rn}$ observed bu" Nelson et al. (1980) in water in some of the Stripa boreholes. A laboratory gamma-spectrometric analys is on this type $0^{*}$ fracture coat ing in the extensometer drift (ST 18) indicated a whole-rock $U$ content ri $44 \mathrm{ppm}$, signif icantly higher than the mean for Stripa quartz monzonite (Table 9 ). If uranium daughter products are in secular equilibrium with their parents in this material, the 44 ppm $U$ would produce $\sim 3 \times 10^{-16}$ grams of ${ }^{22} 2_{R n}$ per gram of material bordering the fracture surface. NElson et al. (1980) have determined that the effective thickness for radon emanation from $1 \mathrm{~cm}^{2}$ of fract e surface is $\sim 2 \mathrm{crn}$ on either side of the fracture. Thus, an effective volume of $4 \mathrm{~cm}^{3}$, ar, with miverial of density $2.6 \mathrm{~g} / \mathrm{cm}^{3}$, an effective mass of $10.5 \mathrm{~g}$ would contribute raden to each square centimeter of fracture surface. Assuming that $10 \%$ of the $222_{R n}$ produced is available for emanation from the fracture lining. this would provide $\sim 10.5 \times 10^{-17}$ grams of $222_{R n}$ to the fracture water from each square centimeter of surface material, or $\sim 16 \mathrm{p}$ icocuries of $222_{R n}$ per square cent imeter. Higher $U$ concentratior.s would produce proportionately greater amounts of radon. 
Fission-track radiography of samples of Stripa leptite supports, with some exceptions, the conclusion derived from $\gamma$-spectrometric measurements that the leptite contains a much lowar uranium concentration than the quartz monzonite. For inctance, in one sample of fractured leptite, S-5, no appreciable discrete conzentrations of uranium were sserved, either in the matrix or in a coarse ipidote-filled fracture cutting it. On the other hand, another sample, $5-6$, a fractured and brecciated leptite, contains uranium concentraticns of from several percent up to $20 \%$ in several very $f$ ine opaque grains, some euhedral, in and adjacent to chlorite, epidote, or carbonate minerals. In addition, uranium concentrations of several percent occur in cracks, with no discrete grains as sociated, in fracture-filling fluorite in this sample. (The flourite in these fractures, and also adjacent to uraniferous opaque grains, is usually colored a deep purple. Purple fluorite, however, is not always associated with uranium.)

Samples of the righboring granitic rocks have lower concentrations of uranium than the Stripa quartz monzonite, with ll-rich opaque grains rare or absent. One sample (j75-14) contains a dense locus of fission tracks associated with uranium in a fracture filled largely by (and obscured by) hematite, while another samp? : contains significant uranium associated with a nonopaque grain, possibly metamict zircon.

Uranium minerals have been observed in chlorite-filled fractures cutting the iron ore at Stripa (Welin, 1964). The $U$ content of this fracture material ranges from a few tenths of a percent (sample ST-23) to ore-grade concentrations as high as a few percent. A detailed examination of the distribution and abundance of $U$ within these fractures and in the wall rock 
adjacent to and away from the fractures, using the fission-track method, may be a good "natural analoque" to the transport and diffusion of $U$ from a discrete source into a crystalline rock matrix.

\subsection{Discussion of Radioelement Data}

\subsubsection{Relative Abundances}

The Stripa quartz monzonite is unusual for its abundance of radiaclements and their ratios. Table 9 indicates the relatively high uranium and thorium contents of the quartz monzonite, compared with other olutons measured in the region as well as with the nearby Malingsbo granite, analyzed for radioelements by Landstrom et al. (1979). Figure 20, the triangular diagram relating the corrected abundances of $U$, Th, and $k$ measured by field ganna spectrometry, shows distinct radioelement fiflds for the Stripa pluton, comedred with leptite and other granitic rocks in the region. An indication of the relatively high content nf the Stripa quartz monzonite is the Th/ 1 ratio, which is considerably lower $(1.2$ in surface and 0.8 in subsurface exposures) than the average of 2.6 measured in most other ar an it ic rocks in the region, the ratio of 3.2 in Malingsbo granite (Landstrom et aI., 1979), or the range of 2 to 4 in granitic rocks in general. Only lwo measurements in other plutons--reddish "granite" in exposures north of Granshyttan (locations 9 and 10, Fig. la)--contain relatively high uranium, similar to Stripa quartz monzonite.

\subsubsection{Variation with Depth}

Table 9, the abundance diagram of Fig. 20, and the plot of $\mathrm{Th}$ and $U$ versus depth in the quartz monzonite (Fig. 21)--all indicate that uranium is depleted in surface exposures of quartz monzonite and leptite at Stripa, relative to its 


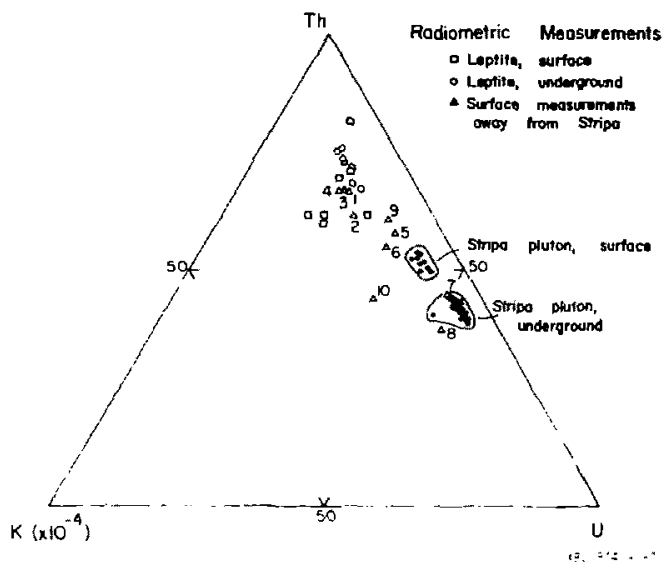

Fig. 20. Triangular diagram showing relative abundances of radioelements. 


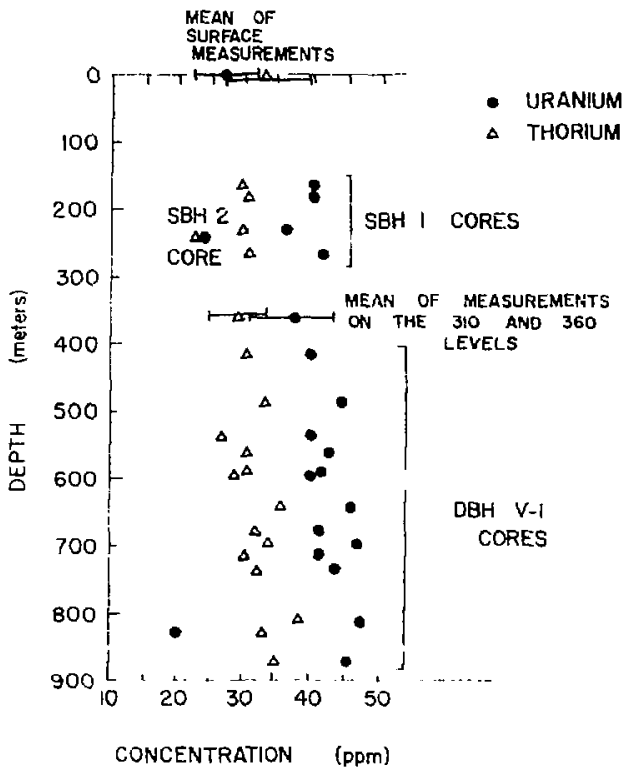

$161915+4$

Fig. 21. Variation of uranium and thorium with depth in the Stripa quartz monzonite. 
abundances in the same rock types underground. The underground/surface $\mathrm{U}$ concentration ratio, is 1.6 for the leptite, 1.4 for the quartz monzonite. A similar relationship holds for thorium in the leptite (1.7) but not in the quartz monzonite $(0.9)$, nor for potassium in either the leptite or quartz monzonite. The Th/U ratio of the quartz monzonite is greater than 1 in the surface exposures and less than 1 in the subsurface.

It is well-documented in the literature that weathered exposures of crystalline rock are depleted in !' compared with relatively unweachered exposures uf the same rock. However, based on one author's (H.W.) experience, the glaciated surface outcrops of the quartz monzonite and leptite at Stripa are comparatively fresh, similar in some instances to glaciated exposures of granitic and metamorphic rock sampled at elevations of 1.5 to $2 \mathrm{~km}$ above sea level in the Sierra Nevada batholith, California. At these Sierran locations there were no appreciab?e differences between surface and subsurface samples in whole-rock uranium contents (Wol lenberg and Smith, 1968).

An explanation for the differences between surface and subsurface $U$ abundances at Stripa must therefore be sought elsewhere. Most $U$ present at Stripa is found in one of two settings: in chloritic fracture zones, in which it is disseminated in relatively low concentrations; or in much higher concentrations in fine euhedral opaque grains (probably a uranium-thorium oxide mineral), commonly associated with fractures (see discussion in section 3.5). This situation may favor the removal of $U$ from surface exposures by slightly acidic near-surface groundwater (Fritz ei al. (1979) indicate that the $\mathrm{pH}$ of water from three wells in the quartz monzonite is $5.15,6.6$ and 7.6$)$. In contrast, $U$ in the Sierra Nevada bathoi ith ic rocks is 
of considerably lower whole-rock abundance than at Stripa and is most stronqly associated with accessorv minerals such as sphene, apatice, $z$ ircon, and allanite. Therefore, $U$ in the Sierra Nevada batholith is less accessible for removal and transport by shallow ground water than at Stripa.

Detailed laboratory analyses of radioelements in cores from the boreholes drilled from the surface to the vicinity of the experimental area (SBH 1,2 , and 3) should help determine whether $U$ increases gradationally with depth or whecher there is a sharp decrease in $U$ near the surface. There is a gradational increase in $\mathrm{U}$ and Th with depth below the $410 \mathrm{~m}$ level shown by the laboratory gamma-spectrometric analyses of cores from the vertical borehole DBH V-1 (Fjg. 21). This apparent increase in radioelements with depth might result from desper portions of the vertical borehole having penetrated a zone of the pluton where late-stage fluids containing axypnile elements concentrated. The variation could also be influenced by the varying proximity of the borehoie to a diabase dike or dikes (see vertical cross section, Fig. 5). The diabase is considerably lower in radioelement content than the quartz monzonite.

\subsubsection{Radioelements and the Age of Groundwater}

Laboratory qamma-spectrometric analyses of $U$ and Th contents in rock were used to better define groundwater ages estimated by Fritz et al. (1979), who employed the heliun-4 method as well as other methods of age dating. In estimating ages of groundwater from the M-3 hole, drilled frufl the $330 \mathrm{in}$ level in the experimental area, and from a zone in hole D\&H V-l between depths of 376.5 and $471 \mathrm{~m}$, Fritz et al. applied the forinula: 


$$
t=\frac{{ }^{H e} \cdot n}{\left(U \cdot P_{u}+T h \cdot P_{t h}\right) \xi}
$$

where $t$ is the apparent age, $4 \mathrm{He}$ is the measured helium- 4 concentration in $\mathrm{CIn}^{3} / \mathrm{cm}^{3}$ of water, $\mathrm{n}$ is the estimated porosity of the rock, $P_{u}$ and $P_{\text {th }}$ are the helium production rates in $\mathrm{cm}^{3}$ per $g$ of radioelement per year, $\xi$ is the rock density, and $U$ and Th are concentrations in the rock in $g / g$. We applied the values of $4_{H e}, n, P_{u}$ and $P_{t h}$ used by Fritz et al. and Th and $U$ contents and rock density determined in this study to solve the above equation for $t$, the apparent age. The values used are listed in Table 10.

Solving for $t$ yields an apparent age of the water in hole $M-3$ of $4.6 \times 10^{4}$ years, and $2 \times 10^{5}$ years for water in hole $\mathrm{DBH} \mathrm{V}-1$. These ages are compatible with the results of ${ }^{14} \mathrm{C}$ dating by Fritz et al. (1979), which indicated that waters discharging on the $330 \mathrm{~m}$ level and in borehole DBHV-1 were recharqed more than to 20,000 years ago. The ${ }^{4}$ He contents in the M3 and DBH V-1 holes differ by a factor of four, as do the calculated ages, because the whole-rock $U$ and Th contents are fairly similar in the two water sampling locations. Greater U contents, such as those occasionally associated with chloritic fracture-filling material (Section 3.5) would result in proportionately younger apparent ages. The difference in ages indicates that the flow path of the reeper of the two groundwater systems was considerably longer than that of the shallower system; it also suggests that the bulk permeability of the rock decreases significantly with depth. 
Table 10. Values usea to calculate apparent ages of waters from Stripa boreholes.

\begin{tabular}{|c|c|c|c|c|c|c|c|}
\hline Hole & ${ }^{4} \mathrm{He}\left(\mathrm{cm}^{3} / \mathrm{cm}^{3}\right)$ & $\begin{array}{r}M(\bar{G}) \\
(g / \mathrm{s})\end{array}$ & $\begin{array}{c}\text { Mean in } \\
(g / g)\end{array}$ & $\Pi$ & $\bar{\xi}$ & $\mathrm{P}_{\mathrm{U}}$ & $P_{\text {th }}$ \\
\hline $\begin{array}{c}M-3 \\
08 H \stackrel{V}{V}-1\end{array}$ & $\begin{array}{l}3.5 \times 10^{-4} \\
1.4 \times 10^{-3}\end{array}$ & $\begin{array}{l}44 \times 10^{-6} \\
30 \times 10^{-6}\end{array}$ & $\begin{array}{l}30 \times 10^{-6} \\
35 \times 10^{-6}\end{array}$ & $\begin{array}{l}2 \times 10^{-3} \\
2 \times 10^{-3}\end{array}$ & $\begin{array}{l}2.62 \mathrm{~g} / \mathrm{cm}^{3} \\
2.62 \mathrm{~g} / \mathrm{cm}^{3}\end{array}$ & $\begin{array}{l}11 \times 10^{-8} \\
11 \times 10^{-8}\end{array}$ & $\begin{array}{l}3.1 \times 10 \\
3.1 \times 10\end{array}$ \\
\hline
\end{tabular}




\subsection{Radiogenic Heat Production and Heat Flow}

The heat production, calculated from the radioelement contents of the Stripa pluton, combined with the measured conductive heat flow, may provide an estimate of the pluton's effective thickness, if a layered model is considered. The heat production, $A_{0}\left(\right.$ in $\left.\mu \mathrm{W} / \mathrm{m}^{3}\right)$, was calculated from the formula of Birch (1954):

$$
A_{0}=10^{-5} \rho(9.69 \mathrm{U}+2.65 \mathrm{Th}+3.58 \mathrm{~K})
$$

where $p$ is the specific gravity of the rock, considered to be 2.62 in the case of rocks of the Stripa region; $U$ and Th are uranium and thorium concentrations in parts per million, and $k$ is the potassium content in percent.

The radiogenic heat productions of the various rocks in the Stripa region are listed in Table 9; the subsurface quartz monzonite averages $11.9 \mu$ $\mathrm{wim}^{-3}$. This compares with $2.8 \mathrm{H} \mathrm{Wm}^{-3}$, considered by He ier and Rogers (1963) as the mean for granitic rocks, and $\sim 7 \mathrm{Wm}^{-3}$ for other plutons in the Stripa reqion and the Malingsbo granite. From Table 9 we see that the radiogenic heat production of the Stripa quartz monzonite is 4 times that of the neiqhoring leptite and 1.75 times the heat production of other plutans in the reqion.

The conductive heat flow is the product of the thermal gradient and the thermal conductivity of the rock within which the gradient was measured. The qradient at Stripa was determined from a plat of the temperature measured by geologists of the Chalmers Tekniska Högskola in hole DBH V-1 (Fig. 22). The temperature versus depth curve is nearly linear from a depth of 160 in ( $570 \mathrm{~m}$ below the surface) to the bottom of the hole, and gives a geo- 


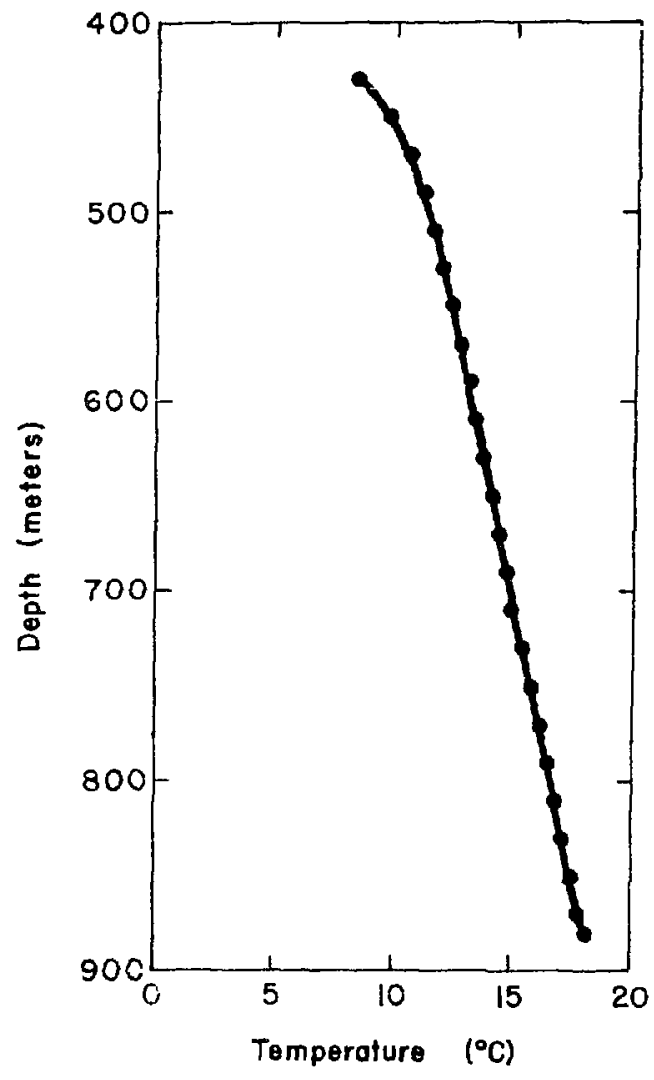

X82 $814-9180$

Fig. 22. Temperature profile in borehole $\mathrm{DBH} \quad \mathrm{V}-\mathrm{J}$. 
thermal gradient of $17.3^{\circ} \mathrm{C} / \mathrm{km} .1$ The product of this gradient and the thermal conductivity of $3.6 \mathrm{Wm}^{-1}{ }^{\circ} \mathrm{C}^{-1}$ (Jeffry et al., 1979) is a heat flow of $61.7 \mathrm{mim}^{-2}$, a value close to that of the regional conductive heat flow (uncorrected for glacial-climatic effects) of the south-central portion of Sweden (Eriksson and Malmqvist, 1979).

A correction may be applied to the observed heat flow to account for the glacial-climatic effects. Eriksson and Malmqvist (1979) point out that because the average annual temperature increased in response to the recession of the continental ice sheet in this region about 9500 years ago, the calculated correction to the observed geothermal gradient adds $3.2^{\circ} \mathrm{C} / \mathrm{km}$. This results in a corrected value of $20.5^{\circ} \mathrm{C} / \mathrm{km}$ for Stripa, and a resint ing corrected heat flow of $73.8 \mathrm{mwm}^{-2}$.

Roy et al. (1968) developed the concept of the linear relationship between conduct ive heat flow and radiogenic heat production. They proposed that for 4 , the observed heat flow,

$$
\mathrm{Q}=\mathrm{q}^{\star}+\mathrm{DA},
$$

where $q^{\star}$ is the heat flow from below the upper portion of the earth's crust with in which must of the radioelements are concentrated, $D$ is the effertive thickness of the radioactive layer, and $A_{0}$ is the $r$ adiogenic heat prinduction.

From heat flow and heat production measurements in central Sweden, 1. and itrom et al. (1979), applying equation (1), estimated that 0 is 15.6

Inere is a slight flow of water from DBH V-1, 120 to 240 1iters per day; this is considered to be too low to have an appreciable effect on the conduct ive geothermal gradient measured in this $56 \mathrm{~mm}$ diameter hole ( $P$. Nelson, private cominunication, 1980). 
$\mathrm{km}$ and $q^{*}=25 \mathrm{mkm}^{-2}$. Accepting these as the bas ic conditions for central Sweden, we $c$ an then estimate the effect ive thickness of the Stripa quartz monzonite, assuminq a $[-1$ ayered case, by a modification of Eq. (1):

$$
Q=q^{*}+D_{1} A_{1}+D_{2} \dot{A}_{2} \text {, }
$$

where $D_{1}$ and $D_{2}$ are the respective thicknesses (in $\mathrm{km}$ ) of the quartz monzonite below $570 \mathrm{~m}$ depth and of rock of an underlying layer, and $A_{1}$ and $A_{2}$ their respective radiogenic heat productions in microwatts per cubic ineter. Solving Eq. (2) using radiogenic heat productions of the quart $z$ monzonite and metamorphic rocks $\left\langle 11.9\right.$ and $2.8 \mathrm{H} \mathrm{hm}^{-3}$ respectively, a corrected heat flow of $73.3 \mathrm{mmm}^{-2}$, a $q^{\star}$ of $25 \mathrm{mmm}^{-2}$, and a $15.6-\mathrm{km}$ thick radioactive layer results in $D_{1}=0.75 \mathrm{~km}, D_{2}=\sim 14.3 \mathrm{~km}$; this configuration suggests a total thickness of $1.3 \mathrm{~km}$ of Stripa quartz monzonite.

Alternatively, consider a layered intrusive configuration: quartz monzonite overlying rock with heat production of the other granitic rocks in lice striparegion $(6.8 \mu \mathrm{km}-3)$. If assume that the effective thickness of the quartz monzonite is at least $1 \mathrm{~km}$ (drilling indicates that it is at least $900 \mathrm{in}$ deen), Eq. (2) yie.ds an effective thickness of $5.4 \mathrm{~km}$ for the underlying granitic rock. These altemative two-layer models are illustrated in Fig. 23.

Howeyer, a layered setting, where the Stripa quartz monzonite is the felsic outer zone of a large granitic pluton or a relatively thin plutonic veneer uverlying a metamorphic basement, are two of several possible configurations: the Stripa pluton is just as likely to have intruded the metamorphic terrane ds an un livered stock or dike. These configurations would not lend themselves to the forogning 5 implified layered model. Therefore, given current informa- 


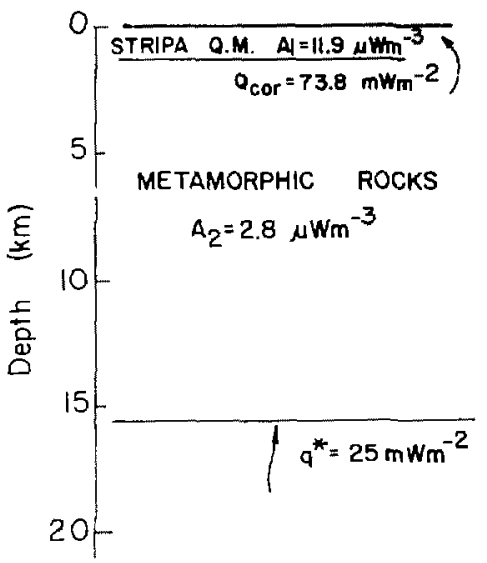

(a)

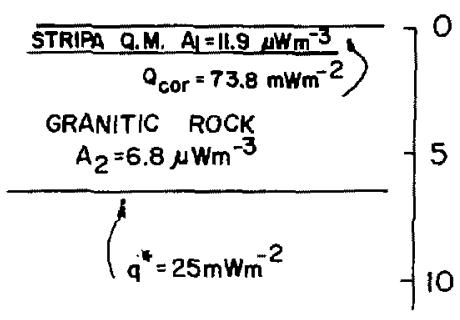

(b)

XBL $814-9182$

Fig. 23. Layered models of a possible configuration of the Stripa pluton. 
tion, all we can state with assurance is that the high radiogenic heat production of the Stripa quartz monzonite, together with the regionally "normal" heat flow measured in the pluton, suggests that the relatively radioactive quart: monzonitic body is small; this body appears to have little if any effect on the regional heat flow. Similar circumstances were observed at the peralkalic plutons of Ilimaussaq, Greenland (Sass et al., 1972) and Pocos de Caldas, Brazil (Vitorello tt al., 1980), where high radiogenic heat production is $r$ it matched by higher-than-normal heat flow. 


\subsection{SUMMARY}

The Stripa quartz monzonite is ubiquitously fractured; fractures are spaced commonly as close as a few millimeters, and in places are less than a millimeter apart; their widths range from $<1 \mathrm{~mm}$ to several cm. Fracture-filling minerals were introduced in at least two stages, the earlier staqe encompassing quartz, sericite, feldspar, epidote and chlorite, and the Tater stage dominated by carbonate minerals. Numerous fractures contain fillings of brecciated parent rock.

In contrast to other plutons in the Stripa reqion, where biotite and hornhionde are prominent mafic minerals and accessory minerals are abundant, in the Stripa auartz monzonite muscovite is common. biotite has been altered to chlorite, hornblende is absent, and accessory minerals are scarce. Though the quartz monzonite and other plutons in the reqion have similar normative aburdances of ouartz, plagioclase and pntassium feldspar, the quartz monzonite contains considerably less iron and magnesium. The apparent ace of the quartz monzonite, determined by K-Ar dating of muscovite, is $1.69 \times 10^{9}$ years, an aqe close to those determined on biotites from granitic rock of the nearby Gusselby and Kloten massifs.

The quartz monzonite is considerably more radioactive than the other plutons near Stripa. Uranium and thorium are in roughly equal abundance (- $30 \mathrm{ppm}$ ) in the quartz monzonite, while the Th/U ratio exceeds 2 in the other granitic rocks. Iranium is often found in euhedral opaque grains, in anhedral opaque grains of a distinctly different mineral, and disseminated in chloritic fracture-tilling material. 
$-74-$

The leptite is mineralogically similar to the Strip quartz monzonite, though its radioelement content is considerably lower. The leptite is also strongly fractured, but epidote appears to be a more prominent fracturefilling mineral than in the quartz monzonite. The contact between the leptite and the quartz monzonite is generally sharp, but there is also some indication of a gradational contact between these two rock types.

Considerations of radiogenic heat production and heat flow suggest that the rock mass encompassed by the Strip quartz monzonite is relatively small; though it contains high abundances of radioelements, these abundances have little effect on the regional heat flow. If the Strip quartz monzonite is part of a layered geologic setting, it is probably not more than $1.5 \mathrm{~km}$ thick; if it is a stock, or dike, or felsic border phase, it would still be relatively small compared with the large granitic plutons exposed in the region. 


\section{ACKNOWLEDGMENTS}

The work reported here was aided greatly in the laboratory by Alan Smith and Beverly Strisower of LBL and Rabert Drake of the University of California. We are grateful for the excellent coaperation at Stripa of Per Axel Halén and the mining staff of Stallsbergbolagen, and Hans Carlsson and Robert Galbraith of the LBL on-site staff. Constructive comments on the text of this report were generously provided by our LBL colleagues, Philip Nelson and Richard Rachiele, as wer: comments by our Swedish colleagues, Sven Ake Larsson, Ingmar Lundstrom and 0tto Brotzen, and by Peter Fritz of the University of Waterloo and Leif Lovborg of the Ris $\emptyset$ National Laboratory, Denmark. The field gamma spectrometer was generously loaned to us by the Earth Sciences Division of the Lawrence Livermore National Laboratory.

This work was supported by the Assistant Secretary for Nuclear Energy, Office of Waste Isolation of the U.S. Department of Energy under Contract DE-AC03-76SF00098. Funding for this project was administered by the Office of Nuclear Waste Isolation at Battelle Memorial Institute. 


\section{REFERENCES}

Birch, F., 1954. "Heat from Radioactivity," in Nuciear Geology, H. Faul, ed., pp. 148-175, John Wi ley, New York.

Deer, W.A., R.A. Howie, and J. Zussman, 1962. Rock Forming Minerals, Longmans, Green, \& Co., Ltd., London.

Eriksson, K.G. and D. Malmqvist, 1979. "A Review of the Past and Present Iilvestigations of Heat Flow in Sweden," in Terrestrial Heat Flaw in Europe, V. Cermak and L. Ryback, eds., Springer Verlag.

Fritz, P., J.F. Barker, and J.E. Gale, 1979. Geochemistry and Isotope Hydrology of Groundwaters in the Stripa Granite: Results and Pre iminary Interpretation. Lawrence Berkeley Laboratory report LBL-8285, SAC-12.

Geijer, P. and N.H. Maqnus son, 1944. De Mellansvenska Järnmalmernas Geologi, Geological Survey of Sweden, Series Ca. $\mathrm{nr}$. 35 .

Geological Si.rvey of Sweden, 1958. Bedrock Map of Sweden, Stockholm.

Giological Survey of Sweden, 1977. Jordartskartan, Lindesberg SV, S.G.U. Series Ae nr 30.

Geological Survey of Sweden, 1979. Geological Map of Lindesberg SW Quadrangle. St ockholm.

Hebert, A.J. and K. Street Jr., 1973. A Nondispersive Soft X-Ray Fluorescence Spectrometer for Quant itative Analys is of the Major Elements in Rocks and Minerals. Lawrence Berkeley Labor atory report LBL-1616.

Heier, K.S. and J.J.W. Rogers, 1963. "Radiometric Determinations of Thorium, Uranium and Potassium in Basalts and in Two Magmatic Differentiation Series" Geoch im. Cusmochim. Acta, vol. 27, pp. 137-154.

Jeffry, J.A., T. Chan, N.G.W. Cook, and P.A. Wither spoon, 1979. Determination of In-Situ Thermal Properties of Stripa Granite from Temperature Measurements in the FuTl-Scale Heater Experiments: Method and Preliminary Results. Lawrence Berkeley Laboratory report LBL-8423, SAC.-24.

Koark, H.J. and I. Lundström, 1979. Berggrundskartan, Lindesberg, S.V., Geological Survey of Sweden, S.G.U. Series AF $\mathrm{nr} 126$.

Landström, D., G. Lind, S- $\AA$ Larson, and D. Malmqı ist, 1979. Värmeflöde $i$ Berg, pub1. B137. Chalmers Univers it y of rechnology, Department of Geology (in Swedish).

Magnusson, E., 1978. Description of the Quaternary Map, Lindesberg, S.V., Geological Survey of Sweden, S.G.U. Ser. Ae, no. 30, Stockholm. 
Ne1son, P., R. Rachiele, and A. Smith, 198il. The Effect of Randon Transpart in Groundwater upon Gamma-Ray Borehole Logs. Lawrence Berkeley Laboratory report $L B L-11180, S A C-30$.

0lkiewicz, A., J.E. Gale, R. Thorpe, and B. Paulsson, 1979. Geology and Fracture System at Stripa. Lawrence Berkeley Laboratory report $\overline{L B L}-8907, \overline{S A C}-21$.

Ulkiewicz, A., K. Hansson, K-E A7men, and G. Gidlund, G., 1978. Geologisk och hydrogeologisk grunddokumentation av Stripa Forsoks station. Karnbranslesakerhet Teknisk Rapport 63.

Roy, R.F., D.D. Blackwell, and F. Birch, 1968. "He at Genera:' on of Plutonic Rocks and Cont inental Heat-Flow Provinces," Earth Planet. Sci. Lett., vol. 5 , no. $1, \mathrm{pp}, 1-12$.

sass, J.H., B.L. Nielsen, H.A. Wollenberg, H.A. and R.J. Munroe, R.J. 1972 "He at flow and Surface Radioactivity at Two Sites in South Greenland", Jour. Geophys. Res., vol. 77, pp. 6435-6444.

Inorpe, R., D.J. Watkins, W.t, RaIph, R. Hsu, and S. Flexser, 1980. Strength and Permeability Tests on U1tra-large Stripa Granite Core. Lawrence Berkeley Laboratory report LBL-71203, SAC-31.

Vitorello, E., V.M. Hamza, and H.N. Pollack, H.N. 1980. "Terrestrial Heat Flow in the Brazilian Highlands," Jour. Geophys. Res., vol. 87, pp. $3 / 18-3788$.

We lin, E., 1964, "Pitchblende-Bearing Vein Fillings in the Stripa and Blanka Iron Ores," Geologiska Föreningens i Stockholm Förhandlingar, vol. 86, pp. 257-270.

Wel in, E., A-M Kahr, and P.H. Lundegardh, 1980. "Rb-Sr Isotope Systematics at Amphibole Facies Conditions, Uppsala Region, Eastern Sweden," Precambrian Research, vol. 13, pp. $87-101$.

Wollenberg, H.A. and A.R. Smith, 1968. "Radiogeologic Studies in the Central part of the Sierra Nevada Bathol ith," Jour. Geophys. Res., vol. 73, no. 4, pp. 1481-1495.

Wollenberg, H.A. 1972. "rission Track Radiography of Uranium and Thorium in Radioactive Minerals, "in Geochemical Exploration, 1972. Institute of Mining and Metullurgy, London, pp. 347-358. 
APPENDIX A: DESCRIPTION OF THIN SECTIONS

Thin sections cut both from core sanples and hand samples are described, with particular emphasis on fracture-fill mineralogy and texture. The non-fractured matrices of the samples from Stripa are not generally described in detail except where they differ significantly from typical .tures sunimarized earlier in the text.

\section{Core Samples}

These samples, designated by an $S$ prefix, were cut from cores from the two surface boreholes $\mathrm{SBH}-1$ and $\mathrm{SBH}-2$, and from the deep borehole DBH-VI (see Fig. 2). They are indexed according to their positions on the respective cores. The more fractured or brecciated portions of the cores were preferentially sampled for thin sections, but relatively unfractured samples were a!so taken.

S-1 $(\mathrm{SBH}-1,51.63 \mathrm{~m})$

Light reddish granitic matrix cut by network of fine fractures grading to microbreccia. Fracture-filling materials are chlorite, quartz, sericite, carbonate, and, possibly, lesser altered epidote; cartonate is the major filling in coarse fractures and breccias.

S-2 (SBH-1, $52.69 \mathrm{~m})$

Foliated leptite matrix containing quartz porphyroblasts, cut with a network of narrow light veinlets. Veinlets (up to $\sim 0.3 \mathrm{~mm}$ wide) consist of very finely intergrown quartz, feldspars, and lesser chlorite and sericite, and locally include near-opaque altered epidote(?). Matrix is also cut by finer veinlets (up to $0.1 \mathrm{~mm}$ wide) of quartz and of carbonate. 
S-3 $\quad(58 H-1,77.81 \mathrm{~m})$

Foliated, porphyroblastic leptite matrix, relatively poor in chlorite. It is cut by numerous prominent discont inuous fractures, $\sim 1 \mathrm{~mm}$ wide, which are filled with a light-colored intergrowth of coarse-grained epidote, carbonate, and fluorite, and include fine fragments broken from the leptite matrix. Epidote also occurs in scattered patches in the matrix, where it is commonly altered and near-opaque.

$\mathrm{S}-4 \quad(\mathrm{SBH}-1,109.92 \mathrm{~m})$

Strongly foliated, non-porphyroblastic dark leptite matrix cut by fractures similar to those of 5-3, and filled with both coarse and fine epidote, quartz, carbonate, and fine sericite. -ridote occurs also in isolated patches in the matrix.

$\underline{\mathrm{S}-5} \quad(\mathrm{SBH}-1,185.17 \mathrm{~m})$

Light reddish leptite matrix, resembling pegmatite in hand specimen, cut by thick light-green fracture zone. Matrix is composed of even, fine-grained mosaic of quartz and microcline, with sparse elongate grains of fine chlorite and epidote defining a foliation. Muscovite is absent, plaqioclase rare. Fracture zone is up to $1 \mathrm{~cm}$ wide, filled with coarse epidote; it grades to microbreccia composed of angular fragments broken from the leftite, and interstitial epidote. In addition, narrower fractures (ranging from $1 \mathrm{~mm}$ wide down to fine strings) with epidote or carbonate-quartz fillings, are zbundant in the matrix. The carbonate-quartz veins are subsequent to the epidote veins, as epidote veins (as well as the large fracture zone) are commonly displaced across them. 
S-6 $(\mathrm{SBH}-1,207.75 \mathrm{~m})$

Fractured and brecciated leptice. Light green breccia $\sim 1 \mathrm{~cm}$ wide is bordered by darker breccia, and between these is a fluorite-filled fracture up to $2 \mathrm{~mm}$ wide. The darker breccia is composed of fragments of leptite with interstitial epidote, chlorite, sericite, and fluorite. The lighter breccia contairs a similar mineralogy, but with much coarser interstitial fillings of fluorite with acicular carbonate and quartz euhedra. The original texture of the matrix is largely obscured by brecciation, but it appears to be poorly fo? iated porphyroblastic leptite.

S-7 $(\mathrm{SBH}-1,232.85 \mathrm{~m})$

Reddish granitic matrix, highly fractured and brecciated. Fractures are filled with chlorite, seririte, and iesser quartz and carbonate. Breccia zones coritain a similar mineralogy dominated by carbonate, and brecciated feldspar grains are generally reddened by diffused hematite alteration, or are totally altered to sericite. Matrix contains traces of garnet.

$\underline{\mathrm{S}-8}(\mathrm{SBH}-1,278.45 \mathrm{~m})$

Dark green, fine-grained amphibolite, cut by prominent light fractures. Amphibole is pale green prismatic actinolite, intergrown with quartz and opaque grains, and including sericite (possible altered feldspar), chlorite, and carbonate in isolated patches and as fillings of fine fractures. The prominent fractures ( $\mathrm{sp}$ to $3 \mathrm{~mm}$ wide) are filled with carbonate, bordered by opaque material (hematite?), and include lenses rich in chlorite and quartz.

S-9 $(\mathrm{SBH}-1,278.55 \mathrm{~m})$

Fracture zane, 5-10 cm wide, cutting amphibolite. Fracture filling consists of narrow white, dark green, light green and red lenses of carbonate, 
quartz, chlorite, sericite, epidote, and hematite. Lenses may he either monomineralic (particularly carbonate, sutured quartz, or chlorite) or fine intergrowths of several minerals. Some include brecciated fragments of either leptite or fine-grained granitic rock. Where sequential relations can be interpreted, calcite appears to be the latest fflling.

S-10 (SBH-1, $280.13 \mathrm{~m})$

Dark green fracture zone in contact with red granitic rock. Fracture zane contains brecciated granitic rock with some well-rounded fragments, and is strongly foliated due to parallel veins and lenses of chlorite, carbonate, altered epidote, and opaque material. The granitic rock is composed mainly of quartz and plagioclase, with little or no microcline, and grades locally into a microbreccia with interstitial sericite. Fine fractures filled with quart $z$ and opaques, carbonate, or sericite-chlorite-altered epidote cut this granitic matrix. The contact between granitic rock and fracture zone is parallel to the foliation of the fracture zone and is marked by a I-smm-wide band of fine-grained granitic rock also foliated parallet to the contact. This rock is composed of quartz and feldspars with elongate chlorite grains, and is not distinguishable from leptite.

S-11. (SBH-1 $291.87 \mathrm{~m}$ )

Light reddish granitic matrix cut by breccic zone $\sim 0.5 \mathrm{~cm}$ wide. Interstices of breccia are filled with chlorite and epidote, and included feldspar grains show hematite alteration. Smaller fractures run sub-parallel and intersect breccia zone, and are filled with epidote, quartz, and chlorite. Coarse epidote prisms (up to $0.5 \mathrm{~mm}$ ) present in some fractures are often fresh, while finer-grained epldote is usually altered and near-opaque. 


\section{S-12 (SBH-1 $320.65 \mathrm{~m})$}

Reddish granitic matrix, relatively unfractured. Chloritized biotites have abundant pleochroic halos, some with distinct grains (zircon?) within. Fractures include a $0.1 \mathrm{~mm}$-wide continuous carbonate ve in, with lesser quartz and fluorite, and finer discontinuous sericite fractures.

\section{S-13 (SBH-1 $371.47 \mathrm{~m})$}

Grey granitic matrix cut by microbreccia composed of broken fragments of granitic parent rock. Interstices of breccia are filled with chlorite, carbonate, sericite, and occasional pyrite. Light green continuous fracture ! $0.2 \mathrm{~mm}$ wide) cuts through breccia zone, and is filled with nearly opaque altered fine epidote (?) bordered by chlorite and sericite. Matrix contains traces of garnet.

\section{$\underline{\mathrm{S}-14}(\mathrm{SBH}-2 \quad 6.79 \mathrm{~m})$}

Medium- to coarse-grained amphibolite composed mainly of blue-green amphibole and strongly altrired plagioclase. Fine fractures (and some coarser, up to $0.5 \mathrm{~mm}$ :.ide) filled with carbonate or epidote are abundant. Plagioclase is altered to fine sericite and coarse epidote or clinozoisite; a vein of plagioclase 1-3 mm wide also cuts the rock, and includes an isotropic mineral (garnet?). Opaque grains are commor, and some are altered epidote. Accessory apatite is also present.

\section{S-15 (SBH-2, $14.62 \mathrm{~m})$}

Strongly foliated fine- to medium-grained amphibolite. Foliation is due to parallel alignment of blue-green amphiboles, and also to parallel lenses alternately rich in plagioclase, quartz, or rhlorite, which are intergrown with amphibole. Plagioclase is very altered to sericite. Chlor- 
ite grains contain abundant pleochroic halos surrounding fine high relief grains (zircon?); chlorite likely formed by alteration of biotite, as partly chloritized biotite grains are intergrawn with chlorite. Quartz-rich lenses have a sutured texture, contain amphiboles, and texturally resemble leptite. Carbonate occurs as fine discont inuous stringers, and epidote occurs as tiny interstitial grains.

S-16 (SBH-2, $16.19 \mathrm{~m})$

Medium-grained dark-green amphibolite cut by light green, mainly epidote-filled fractures. Blue-green amphiboles are intergrown with dusty quartz and lesser epidote and near-opaque grains (altered epidote?). Fractures are commonly $1-3 \mathrm{~mm}$ wide, filled with coarse-grained epidote, with stringers of carborate and quartz within and parallel to the fractures.

\section{$\underline{-17}(\mathrm{SBH}-2,36.01 \mathrm{~m})$}

Fractured light reddish granitic rock in contact with foliated leptite. Prominent fracture cutting granitic rock is $1-2 \mathrm{~mm}$ wide, iilled with quartz, epidote and lesser sericite, and associated with anhodral U-rich opaque grains up to $0.5 \mathrm{~mm}$ in diamet.er. Fine stringers of carbonate and sericite, offshoots from the main fracture, cut the granitic rock, and include similar U-rich grains. The granitic rock is also cut by a clayey quartz-chloritefilled fracture 1-2 $\mathrm{mm}$ wide. The leptite is composed of intergrown quartz, feldspars and abundant muscovite laths, contains quartz porphyroblasts, and is cut by a $0.5 \mathrm{~mm}$ wide chlorite-filled fracture. The contact between leptite and granitic rock is sharp, and is otherwise marked only by sparse epidote grains. 
$\underline{\mathrm{S}-18}(\mathrm{SBH}-2,50.14 \mathrm{~m})$

Leptite in contact with pale reddish aplitic granitic rock. The leptite is porphyrnblastic, moderately foliated, and similar to the leptite of sample S-17. The granitic rock is composed of quartz and myrmekitic plagioclase, with coarse laths of muscovite in preferred orientation perpendicular to the contact with leptite. Both granitic rock and leptite are cut by prominent light green fractures (up to $0.5 \mathrm{~mm}$ wide) filled with altered, near-opaque epidote and by finer quartz-filled fractures. The contact is marked by an abundance of sericite and is in part coincident with an epidote-filled fracture.

S-19 (SBH-2, $50.62 \mathrm{~m})$

Fine-grained, foliated, porphyroblastic leptite with prominent lightgreen iractures up to $3 \mathrm{~mm}$ wide. The fractures are filled with coarsegrained epidote with some intergrown quartz. Quartz stringers run within, and parallel to, the fractures. Fine quartz yeins are also abundant elsewhere in the leptite, and the coarse epidote veins are offset by them.

\section{S-20 (SBH-2, $124.33 \mathrm{~m})$}

Light reddish granitic matrix cut by several types of fractures. A set of black sub-parallel fractures, filled mainly with chlorite and grading locally into microbreccia ( $\leq 1 \mathrm{~mm}$ wide), is must prominent. It is cross-cut by a light green fracture $(0.5 \mathrm{~mm}$ wide) filled with epidote, quartz, and minor fluorite, and by a fine veinlet of carbonate, sericite, and chlorite ( $<0.05 \mathrm{~mm}$ wide) . 
S-21 (SBH-2, $178.01 \mathrm{~m})$

Pyrite-rich fracture zone in reddish granitic rock. Coarse-grained pyrite, with chlorite, sericite, epidote, and near-opaque altered epidote, are densely intergrown several centimeters wide in the fracture zone. The granitic rock is verv rich in microcline and quartz and poor in plagioclase; coarse muscovite crystals are abundant and commonly kinked. The granitic rock is pervasively fractured to yield an angular breccia, with coarse interstices filled with a mineral assemblage similar to that in the fracture zone, and finer interstices filled with sericite, chlorite, or fluorite.

S-22 (SBH-2, $208.54 \mathrm{~m})$

Reddish granitic matrix cut by sets of sub-parallel black fractures grading to microbreccia. Fracture fill is dominated by opaque material, mostly hematite, which obscures much of the other fracture-filling material consisting of chlorite, quartz, and epidote (largely altered).

$\underline{\mathrm{S}-23}(\mathrm{SBH}-2,21.3 .55 \mathrm{~m})$

Brecciated reddish granitic matrix. Granitic fragments grade completely from millimeters to $\langle 0.1 \mathrm{~mm}$ in size, ani are commonly rounded. Interstices of breccia are filled predominantly with fluorite and also contain chlarite and hematite and other opaque material. Fracture ( $\leq 0.5 \mathrm{~mm}$ wide) cutting breccia is filled with carbonate needles in fluorite, with lesser altered epidote(?).

S-24 (SBH-2, $227.05 \mathrm{~m})$

Aplitic dike or inclusion in contact with highly fractured reddish granitic rock. Aplite portion is composed mainly of sutured quartz grains, with lenses or veins of muscovite and lesser opaque grains and chlorite. 
Granitic portion is cut by fractures filled with sericite, chlorite, and opaque grains. Contact is a fracture zone filled with opaque grains, muscovite, chlorite, and accessory garnet. Opaque mineral is at least in part hematite; opaque alteration is also common in muscovite cleavage planes.

$\underline{\mathrm{S}-25}(\mathrm{SBH}-2,251.67 \mathrm{~m})$

Grey granitic matrix, moderately fractured. Fractures are generally $<0.2 \mathrm{~mm}$ wide, and are filled with epidote (1 argely altered), sericite, and chlorite. Matrix contains scattered opaque grains (pyrite?) and traces of garnet.

S-26 $(\mathrm{SBH}-2,252.02 \mathrm{~m})$

Grey granitic matrix, moderately fractured. Fractures range in width up to $1 \mathrm{~mm}$, and are filled with quartz, epidote (largely altered), chlorite, and sericite. They are also filled locally with microbreccia.

$\underline{5-27}(\mathrm{SBH}-2,289.95 \mathrm{~m})$

Pegmatite in contact with grey granitic rock. Contact surface is a fracture $0.5-1.0 \mathrm{~mm}$ wide filled with chlorite, pyrite, muscovite and traces of sphene or epidote. Pegmatite is rich in microcline, and contains dggreyates of coarse muscovite grains with intergrown pyrite, and accessory garnet; it is cut with chlorite-pyrite-filled fractures, and fine quartz veins. Granitic rack in contact with pegmatite contains highly sericitized plagioclase, and is cut by fine chlorite-filled fractures.

$\underline{\mathrm{S}-28}(\mathrm{SBH}-2,324.57 \mathrm{~m})$

Grey to light pink fractured granitic matrix with accessory grains of pyrite anu garnet. Most prominent fracture zone is $?-2$ mm wide, filled with 
a central band of chlorite bordered by intergrom pyrite, sericite, and chlorite, and containing local concentrations of garnet. Widest portions of this fracture zone contain brecciated fragments of parent rock. Other fractures are finer (generally $\sim 0.1 \mathrm{~mm}$ wide), filled with either sericite and chlorite, or fluorite, carbonate, and chlorite.

S-2S (SBH-2, 340.31 m)

Grey granitic matrix, fractured and brecciated. Severai major fractures, up to $1 \mathrm{~mm}$ wide, are filled with coarse crystals of quartz and purple fluorite. Most of sample is cut with a network of fine sericite-chloritefilled fractures which commonly grade to breccia composed of anqular fragments of parent rock and some fluorite grains.

S-30 (SBH-2, 340.73 m)

Granitic matrix, thoroughly brecciated to angular fragments and very finely comminuted material. Interstices of breccia filled with chloritesericite intergrowth, with associated opaque material (altered epidote?). breccia is cut by $0.5 \mathrm{~mm}$ wide fracture filled with purple fluorite, quartz, and accessory garnet; fluprite arains are included locally as fragments in breccia, indicating that brecciation was in part subsequent to fluorite veining.

S-31 (SBH-2, $350.43 \mathrm{~m})$

Light raddish granitic matrix, cut by several zones of parallel fractures, 1-2 mm wide, which grade locally to microbreccia. These fractures are darix green and filled with near-opaque interarowths of altered epidote and chlorite. Very fine fractures also parallel the main fractures, and are filled with grains of quartz and feldspar and traces of fluorite. 
$\underline{\mathrm{S}-32}$ (SBH-2, $358.50 \mathrm{~m}$ )

Maderately fractured reddish granitic matrix intersected by densely fractured and brecciated zone. Less fractured portion is cut by fine chlorite-sericite veins and fine carbonate veins. Densely fractured zone contains fractures filled with intergrowths of coarse-grained chlorite, epidote, and carbonate, as well as irregular patches of muscovite, chlorite, epidote, and opaque grains (pyrite?). Breccia cons ists ef angular and rounded fragnents of granitic rock, with interstitial carbonate, chlorite, and epidote. Cutting the breccia is a fracture $3-5 \mathrm{~mm}$ wide, strongly foliated parallel to the fracture surface, filled with dense chlorite containing lenses of epidote, carbonate and mylonitic breccia derived fron the granitic parent rack.

S-33 (SBH-2, $358.73 \mathrm{~m})$

Dike in contact with granitic breccia, with contact zone between. The granitic breccia is continuous in core sample with S-32; its texture has progressed, however, toward that of mylonite gneiss. It is strongly foliated parallel to the leptite contact, with the foliation defined by lenses filled with a mosaic of finely recrystallized quartz, and by strinqers of sericite and chlorite. Broken and occasionally rounded fragments of granitic rock occur as augen with in the mylonitic breccia.

The contact consists of a 5-mm-wide, strongly fol iated zone resembling the dense fracture zone in $\mathrm{S}-32$, and consisting of alternating convoluted layers of carbonate, chlorite, mylonite, epidote, and pyrite. ..srrow veins of carbonate, chlorite, and epidote which cut the mylonite breccia are truncated by this contact zone. The contact with the dike is sharp, and fine 
fractures nearly perpendicuiar to the contact, filled with carbonate and chlorite, cut the dike.

The dike is composed of a dark, fine-grained rock wich, although logged in drill cores as a leptite, is not similar to the leptites studied here. Its texture is strongly porphyritic, resembling that of a volcanic rock (on the evidence from core samples alone, the possibility that it may be a faulted slice of a volcanic rock cannot be discounted), with plagioclase laths, gerierally elongate parallel to the contact, set in a very fine grained groundmass. Plagioclase is strongly altered to sericite and chlorite, relict pyroxene(?) grains are altered entirely to chlorite, and the qroundmass is coated with a clay veneer.

\section{S-34 (DBH V-1, $4.55 \mathrm{~m})$}

Grey granitic matrix, relatively unfractured, with occasional discon$t$ inuous fractures filled with sericite and chlorite. One prominent fracture, 0.? $-0.5 \mathrm{~mm}$ wide, cuts the matrix, and is filled with chlorite, carbonate, sericite, and pyrite, with lesser quartz and traces of epidote.

S-35 (DBH V-1, $16.07 \mathrm{~m})$

Grey to light pink granitic matrix, larşely brecciated. Interstices of breccia are mainly chloritic, with lesser carbonate. Fractures filled with carbonate and quartz cut the breccia, and most are discont inuous.

$\underline{S-36}(\mathrm{nBH} \mathrm{V}-1,16.12 \mathrm{~m})$

Granitic breccia similar to S-35. Carbonate occurs as a common fracture filling, with quartz. It also occurs as isolated patches with in the breccia, where it is somet imes associated with chiorite, opaques, or traces of eoidote. 
5-37 (DBH V-1,73.30 m)

Grey granitic matrix, cut by numerous fractures. Most fractures are light green, $<0.5 \mathrm{~mm}$ wide, and filled with epidote, sericite, and quartz, with local accumulations of pyrite euhedra. These fractures are sub-parallel; locally they converge and may be filled with microbreccia. Other fractures are oriented near-derpendicular to this set (without apparent offset), and are filler with chlorite, sericite, and, locally, pyrite.

$\underline{5-38}$ (DBH V-1, $125.20 \mathrm{~m})$

Grey granitic matrix, relatively unfractured, containing traces of garnet. Some very fine iractures, filled with sericite and chlorite, are present; these are of small extent and usually adjacent to primary mica grains.

S-39 (OBH $\vee-1,168.97 \mathrm{~m}$ )

Light grey garnetiferous granitic matrix (aplitic), lacking primary biotite. Garnets range up to $1 \mathrm{~mm}$ in diameter, are pink and of ten rounded, and are comisnly fractured and partly altered to chlorite and sericite. The matrix is cut with fractures up tc: $0.2 \mathrm{~mm}$ wide filled in part with chlorite, quartz, and lesser carbonate and fluorite, and in part with microbreccia.

$\underline{\mathrm{S}-40}$ (DBH V-1, $264.87 \mathrm{~m}$ )

Grey granitic matrix, moderately fractured. Two narrow (0.1 mm wide), convergent light green fractures cut the matrix, and are filled with a near-opaque, fine-grained intergrowth of altered epidote, sericite, and chlorite. Where they converge, they form one fracture, $3 \mathrm{~mm}$ wide, filled with microbreccia with interstitial chlorite. The matrix is othenwise cut only by narrow discontinucus chlorite- and sericite-filled fractures. 
S-41 (DBH V-1, 299.39 m)

Brecciated grey granitic matrix. Fragments in breccia include finely comminuted material and sub-rounded clasts, up to $1 \mathrm{~cm}$ in diameter, of relatively unfractured granitic rock. Interstices of breccia are filled with chlorite and iesser hematite. Breccia is cut by narrow light green epidotefilled fractures, and by a thicker fracture $(>2 \mathrm{~mm})$ filled with coarse epidote and finely intergrown sericite and chlorite.

\section{S..42 (DBH V-1,3i3.14 m)}

Red araanitic breccid, cut by light green mylonitic zones. Breccia consists gf finely ground granitic rock, orobably largely recrystallized, with dispersed sericite, chlorite, and hematite, and includes granit ic fi ag̣ments, both rounded and angu?ar, up to $0.5 \mathrm{~mm}$ in diameter. Narrow fractures filled with quartz and chlorite cut the breccia. Mylonitic zones are characterized by sub-parallel aliqnment of convoluted lenses containing opaque material (partly hematite, partly altered epidote?), fine-orained quartz, or chlorite-sericite intergrowths, all rich in clay and including fine granitic breccia. Carbonate is nearly or entire?y absent.

$\underline{5-43}$ (OBH V-1, $349.50 \mathrm{~m})$

Fine-grained grey granitic matrix, with isolated interoranular patches of epidote up io $1 \mathrm{~mm}$ in diar,eter. The matrix also contains very abundant fine intergrowths of quartz and feldspars and less commonly sericite along grain boundaries, and lacks primary biotite. The matrix is cut by ane major fracture, 3-4 mm wide, filled with finely intergrown chlorite and quartz, and including fine granitic microbreccia, and lenses rich in epidote and clay. Carbonate occurs in tiny stringers running paralle? to this main fracture, 
and in occasional intergranular patches like those filled with epidote.

S-44 (DBH V-1, $392.71 \mathrm{~m}$ )

Grey g̣ranitic rock in contact with dark grey foliated granitic rock resembling leptite. Non-foliated portion is typical Stripa quartz monzonite, composed of sutured quartz, plagioclase (sericitic), microcline, and muscovite and chloritized biotite which are largely interstitial. It is also characterized by a very uneven grain-size distribution. The foliated granitic rock contains a similar mineralogy, but has a much more even grain-size distribution, arid a foliation defined by parallet orientation of abundant chlorite grains. Small high-relief grains (zircon or allanite?) are common in the chlorite. Both foliated and non-foliated portions are cut by fine fractures filled with chlorite and sericite and in some cases epidote. The contact between the two granitic rocks is not as pronounced in thin section as it is in hand specimen, and is marked only by thin veinlets of chlorite rich in the high-relief mineral.

S-45 (DBH V-1, 392.86 m)

Reddish granitic rock in contact with dark grey foliated granitic rock, very similar to $S-44$. The foliated, leptite-like portion contains coarse-grained poikilitic microcline, and relatively little quartz. The contact is a piane of abrupt textural transition, but is not otherwise marked, as with a fracture. Prominent light green narrow fractures $<00.5 \mathrm{~mm}$ wide) cut both portions of the thin section at high angles to the contact, and are filled with epidote, quartz, and traces of carbonate. 
S-46 (DBH V-1, $406.71 \mathrm{~m}$ )

Grey fractured granitic matrix in contact with breccia. Breccia is composed of granitic fragments commoniy up to $1 \mathrm{~mm}$ in diameter, generally angular, with interstices filled with finer fragments, chlorite, and patches of epidote. The non-brecciated granitic rock is cut with fine fractures filled with near-opaque altered epidote and/or hematite, and microbreccia.

$\underline{\mathrm{S}-47}$ (DBH V-1, $407.97 \mathrm{~m})$

Complexly fractured granitic matrix. Two prominent sub-parallel fracture zones, up to $3-4 \mathrm{~mm}$ wide, are filled mainly with carbonate, and contain lenses of microbreccia, chlorite, altered epidote, and opaque material. Another coarse fracture, 2-3 $\mathrm{mm}$ wide, runs between them, and is light green in color and filled mainly with near-opaque altered epidote. In addition, fine fractures filled with quartz, chlorite, epidote, opaques, and lesser carbonate cut the matrix at varied orientations. The matrix itself shows extensive alteration of primary muscovite to chlorite and opaques, and contains traces of garnet.

S-48 (DBY V-1, 414.61 $\mathrm{m}$ )

Brecciated red çanitic matrix, cut by thick light greer fracture zone. Brecciation is due to a network of irregular fine fractures which cumpletely pervade the rock, and which are filled with sericite, chlorite, or altered epidote, and locally with quartz. Fracture zone is $\geq l \mathrm{~cm}$ wide, and is filled with a near-opaque dense intergrowth of altered epidote, chlorite, and clay, with included granitic fragments and occasional carbonate patches. 
S-49 (DBH V-1, $464.74 \mathrm{~m}$ )

Grey granitic matrix, moderately fractured. Prominent dark fracture, $\sim 0.5 \mathrm{~mm}$ wide, is filled largely with altered epidote and broken granitic parent rock, and has very thin borders of sericite. Finer fractures filled with carbonate and quartz cut the matrix parallel to the main fracture. Matrix contains traces of garnet.

2. Hand Samples from Stripa and Vicinity

These samples are designated by an ST prefix. For sampling localities see Figs. 2,3 , and 4 .

$\underline{5 T-1}$

Grey strongly fo: iated leptite, composed of finely intergrown quartz, lesser plagioclase and microctine, and abundant elongate parallel muscovite grains. Quartz porphyroblasts are abundant. Plagioclase is largely altered to sericite. Muscovite is often intergrown with chlorite and, to a lesser extent, with epidote. Fine fractures are filled with sericite and chlorite, and often witn hematite as well.

ST -3

Reddish granitic matrix, relatively unfractured. Only fine, quartzfilled fractures are present, as well as discontinuous cracks filled with chlorite, seric::e and some dispersed hematite.

$\underline{51-9}$

Light reddish granitic matrix, cut by a dark fracture ( $\leq 0.5 \mathrm{~mm}$ wide) filled with chlorite, sericite, and locally with microbreccia. The matrix contains abundunant cracks filled with chlorite, sericite, or finely inter- 
grown quartz and feldspars, and contains traces of garnet.

$\underline{\mathrm{ST}-12}$

Light reddish granitic matrix, similar to ST-3, with occasional stringers of carbonate ( $0.03 \mathrm{~mm}$ wide).

$\underline{S T-18 a}$

Light grey granitic matrix, relatively unfractured and simi lar to ST-3, but with extensive sericitic alteration of plagioclase. Contains accessory pyrite.

ST-19

Grey granitic matrix, similar to ST-i8a.

$\underline{5 T-2 I}$

Light reddish granitic matrix, similar to ST-12.

$\underline{\text { ST-27 }}$

Dark grey strongly foliated leptite, texturally similar to ST-1, but slightly coarser-grained and lacking porphyroblasts. Feldspars are largely absent, a?traugh small areas occur which are rich in plagioclase to the exciusion of quartz and in which the foliation is less well defined. Biotite, partly replaced by chlorite, is very abundant, and, a long with less abundant muscovite, defines the foliatior. Biotite grains contair fine elongate birefringent grains (zircan?). 
ST -32

Fractured, light grey leptite, coposed of intergrown quartz, plagioclase (very altered), and microcline, with lesser muscovite and chlorite. Foliation is not strongly pronounced. Most prominent fractures (up to $1 \mathrm{~mm}$ wide) are filled with quartz, and finer fractıres are generally filled with very fine irtergrowths of chlorite, quartz, and feldspars, locally resemb ling microbreccia.

$\$ T-35$

Black, fine-grained diabase composed mainly of intergrown plagioclase, pyroxene, and magnetite. Pyroxene is largely altered to chlorite, sericite, and needle-like growths of an opaque mineral. Plagioclase is partly altered to sericite. Interstices between grains are generally filled with fine-grained alteration products, including clay, chlorite, and possibly epidote. One prominent fracture, $0.5 \mathrm{~mm}$ wide, cuts the diabase, and is filled with chlorite, carbonate, and lesser magnetite.

\section{Hand Samples from Other Granitic Massifs Near Stripa}

These samples are from other granitic massifs near Stripa. See Appendix C for sources and locations. Fractures are less abundant and pronounced in these samples than in the Stripa rocks, and thin section descripticns are thus concerned mainly with the matrix.

\section{Gusselby Massif}

$\underline{\mathrm{J} 74-1}$

Red, medium-grained granitic rock. Microcline is abundant and coarsegrained, with some sericite alteration. Biot ite is relatively sparse and is partly altered to chlorite (preferentially along cleavage planes), partly 
fresh, and often contains dense pleochroic halos, with discrete, nearisotropic grains within. Muscovite is present but not abundant. Fine zircon(?) grains are scattered among intergrowths of biotite, muscovite, chlorite, and opaque grains (pyrite?). Opaque grains and apatite occur elsewhere as accessory minerals. Sericite, chlorite, and intergrowths of quartz and feldspars fill fine discontinuous cracks within grains or along grain boundaries, resembling the Stripa quartz monzonite in this respect.

$\underline{375-1}$

Red granitic rock, similar to J74-1, with lesser microclime and more abundant, relatively fresh biotite. Also contains carbonate locally intergrown with micas, chlorite, and opaque grains, and has traces of fluorite.

\section{$\underline{L 79-1}$}

Light reddish granitic rock similar to J74-1 and J75-1, but more extensively altered. Biotite is thoroughly chloritized, and plagioclase is very clouded with diffused clay alteration and cut with cracks filled with inlorite and sericite. Muscovite is nearly absent.

\section{Dammsjön Massif}

$.375-4$

Coarse-grained, light reddish granitic rock, friable due to network of fine, unfilled cracks. Plagioclase is very cloudy, commonly with sericite or chlorite alteration, occasionally with epidote, opaque (hematite?), or carbonate alteration. Microcline is particularly coarse-grained and often poikilitic. Biotite is very abundant, coarse-grained, and fresh, with only ininor chiorite alteration. Primary muscovite is absent. Green hornblende is commonly intergrown with biotite, as are small grains of sphene and possibly 
zircon. Apatite is a common accessory mineral; fluorite is present in trace amounts.

$\underline{\mathrm{J}} 75-7$

Coarse-grained grey granitic rock, very similar to J75-4, but somewhat less crazked and friable. Biotite is somewhat more shloritized; hornolende is less abundant. Sphene and other accessory minerals are present, 2 , in J75-4.

$\underline{\mathrm{J} 75-8}$

Red coarse-grained granitic rock similar to J75-d and J-75-7, with more abundant hornblende, and pattly chloritized biotite. Also, spinene and apatite are more abundant, and of ten more coarse-grained, tnan in the above samples. Rounded grains, possibly zircon alteres to a law-bireíringence product, are common in biotite. Hematite alterition occurs along cracks and grain boundaries.

$\underline{375-9}$

Red granitic rock, somewhat finer-grained than J75-4, J75-7, and J75-8. Plagioclase is very altered; biot ite is less abundant, finer-grained, and more chloritized; hornblende is also less abundant. Epidote Jccurs as an alteration product of plagioclase and biotite; an epidote-like mineral (allanite?) of primary origin is also present. Hematite accurs in cracks in various minerals, and in discrete grains in chlorite and in plagioclase. Accessory sphene and apatite and traces of fluorite are also present. 
$\underline{J 75-14}$

Fine-grained, light-brown granitic rock with primary muscovite (minor, mostly interstitial, late crystallization), and only traces of biotite. Secondary alteration products, principally hematite and epidote, are common. These occur in clusters along grain boundaries and in cracks, and also as fillings of several parallel continuous fractures. The fractures are up to 1 mm wide, and are filled mainly with epidote (somewhat altered), and a light mineral resembling microcline with a very dusty clay alteration. Also rare grains of a pink pleochroic mineral are present.

\section{Kloten Massif}

$\underline{\underline{75-9}}$

Fine-grained yellow, somewhat foliated granitic rock, with a pegmatitic lens oa-allel to the foliation. Biotite is the only mafic minerd, and it occiors sparsely as small, interstitial grains (late crystallization). Fine-grained quartz is common along $s$ aln boundaries, as is sutured quartz; thus this sample is texturaliy similar to siripa quartz monzonite. Fine, very high relief, near-isotropic grains generally rounded (averaging 0.05 Im diameter), are often associated with fine cracks in quartz or feldspars. Accessory opaque grains (pyrite) are also present. Hematite altaration occurs aiung grain boundaries and cracks.

\section{$\underline{6.75-10}$}

Grey granitic rock with megacrysts of pink poikilitic microcline. Textur: is hererogeneous, with coarse grains alternating with fine-grained intergrowths. Biotite is generally chloritized and finely intergrown with quartz. Plagioclase is commonly coarse-grained and somewhat poikilitic, with 
sericite and, occasionally, chlorite aiteration. Fine-grained zones appear lensoid or vein-like, and probably originate from a late-crystallizing liquid. They contain finely-intergrown quartz, feldspars, biotite-chlorite, and fluorite, usually surrounded by somewhat coarser sutured quartz. Accessory grains of an altered prismatic mafic mineral, sometimes $\geq 1 \mathrm{~mm}$ in length, with included epirote or zircon, are present.

\section{$\underline{C 75-11}$}

Medium- to coarse-grained foliated grey granitic rock. Feldspars and quartz are commonly coarse-grained, and mafic minerals include abundant biotite (generally fresh), lesser green hornblende, sphene, and opaque grains. The mafic minerals are usually intergrown in aggregates, with dccessory fluorite (abundant), apatite and carbonate. Although locally coarse-grained, these aggregates generally have the texture of the very fire-grained elongate intergrowths of $\mathrm{C} 75-10$, suggesting that they are due to late stage crystallization. The altered mafic grains present in 675-10 are aiso found in this sample.

\section{I $75-10$}

Light reddish-brown granitic rock, generally fine-grained but heterogeneous in texture and to some degree in mineralogy. Coarser lenses comprise large grains of microcline, often poikilitic and and somewhat altered, lesser coarse plajioclase grains extensively altered, and sutured quartz grains. Biotite is sparse, somewhat chloritized, and often intergrown with opaque grains. Darker lenses rich in biotite are also present in the rock. Hematite alteration occurs along grain boundaries and cracks. 
I $75-11$

Medium-grained, dark granit ic rock, with occasional coarse microcline grains. Mafic minerals are abundant, are generally intergrown in aggregates, and include biotite (fresh), green hornblende, sphene, opaque grains, and accessory tluorite and apatite. Locally these intergrowths grade toward the fine, late-crystallized texture common in $675-10$ and $775-11$, but typically they are much coarser-gralned. Tiny grains of zircon(?) and/or allarite(?) a iso occur as accessories.

$\pm 75-22$

Medium-grained granitic rock, similar to $175-11$ but lighter and more altered. Matic minerals are the same as in I 75-11, occurring: so in aggregates, and are somewhat less abundant. Alteration takes the torb or partial chiorization of biotites (which are more readsh than those of $175-i 1$ ), more thorough alteration of teldspars, and hemotite alteration in cracks.

\section{$\underline{I L} 79-?$}

Fine- to medium-grained light yellaw-orown gianit ic rack, texturally neterogenous, with coarse-grained and fegmatitic lenses. Biotite is very soarse, and is mostly chloritized; prinary misco:ite is preserit in trace amounts. Plagioclase is extensive:y altered. Other alteration is simijar to that of $375-14$, but to a lesser extent, and includes $t$ ine epidote and/or hematite in cracks, and thin discontrmuous clay-rich veins. 
APPENDIX B. RADIOELEMENT CONTENTS, SURFACE AND UNDERGROUND MLASUREMENIS, STRIPA

Kadiogenic

He at Prod.

Location

Kock

$\underline{K}(\boldsymbol{x}) \underline{\mathrm{U}(\mathrm{ppm})}$

Ih (pprn) Th/U

(cal $\left.\times 10^{-13} \mathrm{~cm}^{-3} \mathrm{sec}^{-1}\right)$

Surtace measurements, vicinity of stripa mine

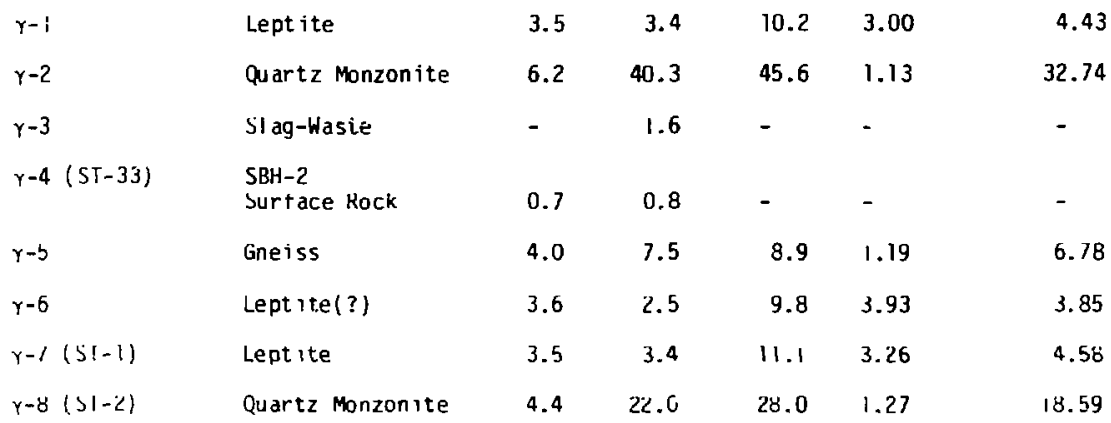

Surtace measurements on quartz monzonite, vicinity of SHH-3

$\begin{array}{lllllll}r-57 & \text { Quartz Monzonite } & 3.85 & 26.2 & 29.2 & 1.11 & 21.10 \\ r-58(j \mid-35) & \text { Quartz Monzonite } & 4.1 & 26.9 & 33.1 & 1.23 & 22.27 \\ r-59 & \text { Quartz Monzonite } & 4.4 & 24.2 & 11.3 & 1.29 & 20.44 \\ 1-60 & \text { Quartz Monzonite } & 4.8 & 28.6 & 38.3 & 1.34 & 24.28 \\ i-9(3 \mid-3) & \text { Quartz Monzonite } & 4.1 & 24.7 & 32.7 & 1.32 & 20.89 \\ y-10(S \mid-4) & \text { Quartz Monzonite } & 4.2 & 22.1 & 27.4 & 1.24 & 18.51 \\ y-11(S \mid-5) & \text { Quartz Monzonite } & 5.2 & 27.1 & 31.3 & 1.17 & 22.42 \\ y-12(S i-32) & \text { Leptite } & 2.2 & 2.9 & 11.5 & 3.97 & 4.06 \\ y-13(5 T-38) & \text { Leptite (?) } & 2.6 & 4.4 & 17.0 & 3.86 & 5.92\end{array}$


Appendix $B$ (cont inued)

Radiogenic

He at Prod.

Location

Rock

$\underline{K(x)} \underline{U}(\mathrm{ppm}) \underline{T h}(\mathrm{ppm})$

Surface measurements on granitic rocks away from Stripa

$\begin{array}{lllllll}\gamma-61 \text { (ST-40) } & \text { Urgranit } & 4.3 & 6.8 & 22.3 & 3.28 & 8.58 \\ Y-61 a & \begin{array}{l}\text { Mica Schist } \\ \text { (Diotite) }\end{array} & 3.6 & 6.1 & 15.7 & 2.57 & 6.95 \\ r-62(S T-41) & \text { Pinkish Urgranit } & 6.2 & 8.8 & 30.1 & 3.42 & 11.44 \\ Y-6 j(S T-43) & \text { Pinkish Urgranit } & 5.5 & 7.1 & 25.3 & 3.56 & 9.50 \\ \gamma-64(S T-44) & \begin{array}{l}\text { Mica Schist(?) } \\ \text { roliated granite(?) }\end{array} & 1.1 & 4.1 & 7.1 & 1.13 & 3.85\end{array}$

Surtace measurements on granit ic rocks away trom Stripa (cont inued)

$\gamma-65(S T-4 b) \quad$ Codr $z \approx$ granite

and pegmatite

$4.7 \quad 1.4$

Predominantiy

quartz; some

teldspar $\quad 1.6 \quad 4.0$

$\operatorname{sen} 15 t$

$<.6 \quad 1.3$

$11.9 \quad 1.63$

6. 84

Surtace granite north of Gränshyttan

r-ob: $(-40) \quad$ Granite, tine-

med. grained

$r-6,(5[-4 /)$

Coar se-pegmatite

Lt. granite

Med. grained

redoish granite

$Y-58(S T-48)$
$5.0 \quad 40.9$

36.7

0.90

31.41

$\begin{array}{llll}7.8 & 18.6 & 27.5 & 0.71\end{array}$

29.17

$4.0 \quad 14.7$

28.8

1.96

14.21

Lept ite north of mine area on Gul Iolankabanan

$\gamma+69(5 I-49)$

Lept ite

$3.1 \quad 6.9$

16.2

2.35

1.40

$r-10$

Lept ite

1.94 .9

28.9

5.90

1.98 
Append ix B (cont inued)

Radiogenic

Heat Prod.

Location

Kock

$\underline{K}(\mathrm{x}) \underline{\mathrm{y}(\mathrm{ppm})}$ Th (ppm)

Underground Measurements

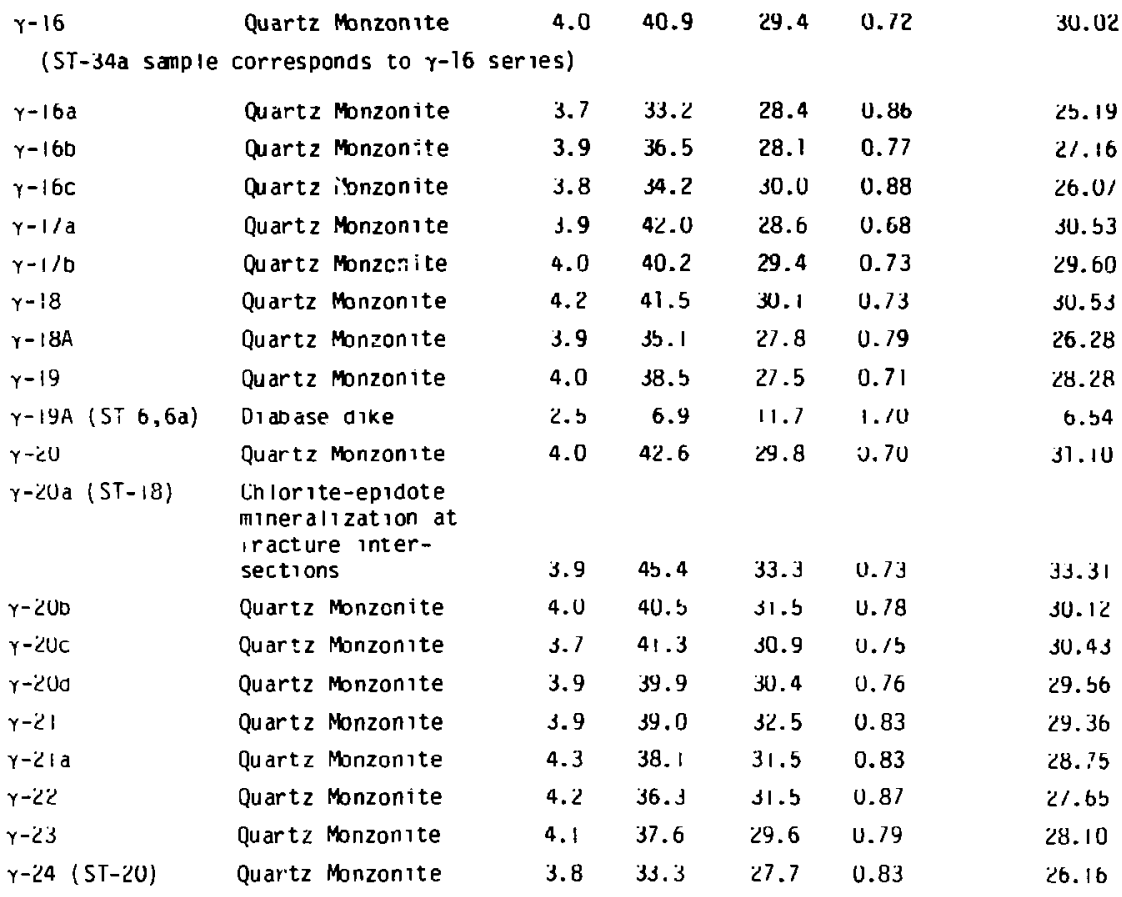


Appendix 8 (continued)

Radrogen ic

Heat Prod.

\begin{tabular}{|c|c|c|c|c|c|c|}
\hline Locat inn & Rock & $K(x)$ & $U$ (ppm) & Ih $(p p m)$ & Th/U & $\left(\mathrm{ca}\left(\times 10^{-13} \mathrm{~cm}^{-3} \mathrm{sec}^{-1}\right)\right.$ \\
\hline$Y-25$ & Diabase dike & 2.4 & 3.2 & 11.0 & 3.44 & 4.20 \\
\hline$y-26$ & Quartz Monzon?:e & 3.7 & 39.1 & 52.6 & $0.8 \mathrm{~J}$ & 29.39 \\
\hline $1-27(51-22)$ & $\begin{array}{l}\text { Reodish uartz } \\
\text { Honzonite }\end{array}$ & 4.2 & 43.4 & 32.6 & 0.15 & 32.07 \\
\hline$r-28$ & Quartz Monzonite & 4.2 & 38.5 & 31.1 & 0.81 & $2 B .90$ \\
\hline+-29 & Quzrtz huzen:te & 4.0 & 36.6 & 29.3 & $0.8^{\prime 3}$ & 21.43 \\
\hline$:-30$ & $\begin{array}{l}\text { Vuartz Munzonite de } \\
\text { inial win Leptite }\end{array}$ & 3.5 & $\angle 5.5$ & $2: 2$ & 0.33 & 19.47 \\
\hline$x-9 !$ & $-=f$ tile at curlact & 1.9 & $\{j .3$ & 1.3 & $1 . j 2$ & 11.60 \\
\hline$\gamma-3<; S T-2 i !$ & Quar:z honzonite & s.b & $3 / .6$ & Щ. : & 0.8 & $2 i / 1$ \\
\hline$\gamma-3 j$ & Quartz Monzonite & 3.9 & 30.1 & $3 Z .6$ & 0.84 & 29.20 \\
\hline$r-j 4\langle S T-3 b)$ & Dlabase dike & $<.6$ & $i .6$ & 13.0 & $1 . i 1$ & 1.19 \\
\hline$x-3 b$ & $\begin{array}{l}\text { He tire Jurtare cu } \\
\text { kes diartz monzonite } \\
\text { ned- Lent ite contact }\end{array}$ & 4.4 & 56.5 & 36.5 & 0.65 & 40.56 \\
\hline$Y-30$ & lept lte & 3.1 & 4.7 & $20 . j$ & 4.40 & 0.81 \\
\hline$x-3)(S T-16)$ & $\begin{array}{l}\text { Lept ite, Ure with } \\
\text { sops- II }\end{array}$ & 7.7 & 35.: & 11.2 & 0.34 & $\because 15$ \\
\hline$i-36 \mid s i-8 j$ & ke-in!sh juartz Mond. & 3.5 & 53.1 & 28.5 & 0.85 & 25.07 \\
\hline$\gamma-35 ; \supset I-9\}$ & Qu:1:z ikizon:ie & 3.1 & 35.0 & 28.8 & $0.8 \ddot{z}$ & 26.46 \\
\hline $3-40 !(51-10)$ & (h. artz khizonice & 3.7 & 36.1 & 30.0 & 0.79 & 28.38 \\
\hline $1-41(57-11)$ & $\begin{array}{l}\text { Kendish Quirtz } \\
\text { Monzonite }\end{array}$ & 3.9 & 41.5 & 31.6 & 0.76 & 30.71 \\
\hline$y-42(51-12)$ & Quarcz Monzonice & $4,1)$ & 39.6 & sU. 1 & 0.11 & 29.39 \\
\hline $1-43(5 T-13)$ & $\begin{array}{l}\text { keld ish aud a monz. } \\
\text { near lept ite contact }\end{array}$ & 3.5 & 29.1 & 24.2 & 0.83 & 22.03 \\
\hline$i-44(\$ 7-14,14 a)$ & Levt ite at contact & 2.8 & 4.2 & 18.1 & 4.31 & 6.02 \\
\hline$y-45(5 i-15)$ & Iron ure & 2.1 & 3.3 & 9.8 & $2.9 i$ & 4.00 \\
\hline$Y-45 A$ & Ure zone. Mud on toor & c. 9 & 61.8 & $13.1 \mid$ & $0.2 \mathrm{~s}$ & 39.63 \\
\hline$\gamma-76(s[-11)$ & Pegmatite (0isart $\bar{z}-m i c a)$ & 4.5 & 37.0 & 24.6 & U. 66 & 21.03 \\
\hline
\end{tabular}


Appendix B (cont inued)

Radogentc

Heat Proo.

Location

Rock

$\underline{K(z)} \underline{U(p p m)}$ Th (ppm) in/U

(calxio-13 $\left.\mathrm{cm}^{-3} \mathrm{sec}^{-1}\right)$

$360-m$ Leve I

$\gamma-47$

$(\$ 1-23,23 a, 210) \quad$ U ore zone

$\begin{array}{lllll}3.2 & 85.8 & 17.1 & 0.20 & 54.69\end{array}$

$\gamma-48($ ST-24) Ked Quartz

Monzon 1 te

$\begin{array}{lllll}3.3 & 31.0 & 24.9 & 0.80 & 23.23\end{array}$

$\gamma-49(S i-2 b) \quad$ Leptite

$\begin{array}{llll}2.5 & 4.7 & 18.0 & 3.83\end{array}$

b. 24

$\gamma=50$

Leptite

2.2

3.5

7.2

4.91

3.33

$r-b 1$

Lept ite

$2.5 \quad 4.6$

15.3

3.33

3. 15

$\gamma-32(5 T-26)$

Kec quartz inonzonite near leptite contact

$\begin{array}{llll}3.6 & 17.5 & 14.2 & 0.81\end{array}$

13.52

$\gamma-53$

Banded Fe ure

2.9

3.9

14.9

3.82

3.35

$\gamma-54(S T-27)$

2.8

6.0

18.13 .02

1.10

$Y-3 b(S \Gamma-28)$

2.6

3.9

$1 / .7$

4. .74

5. 14

$Y-36$

Leptite

$2.7 \quad 3.6$

18.8

5.22

5. 16 
APPENDIX C. DESCRIPTION AND LOCATION OF JAMPLES PROVIDED BY

I. LUNDSTROM, SWEDISH GEOLOGICAL SURVEY

SAMPLES

J75-1

Reddish, microcline-porphyritic, homogeneous granite. The sample probably blasted by fire. No obvious signs of weathering. Loc. SW of Gusse1hyttan IIF SV/2d. Foord: $661342 / 146806$.

L. $79-1$

Aplitic, red heterogeneous granite. The samples were taken approximately $30 \mathrm{~cm}$ below the weathering surface in a small road-cut. Loc. Small road-cut $500 \mathrm{~m}$ NE of Långä̈gen, NE of Lindesberg, IIF SV/2e. Coord: 661256/147127.

i $74-1$

Red, homogeneous, sparsely microcline-porphyritic granite. Cf. anal. 7594057. The samle is taken approx. $1 \mathrm{~m}$ below the weathering surface in a sma? i quarry. Loc. Small quarry $450 \mathrm{~m}$ NE of Kallhagen, IIF SV/2d. Coord: so $10001,146970$.

$\because 75-4$

Coarse, microcline-porphyritic, homogeneous granite. Cf. anal. 7594251 . The sample is taken from we athering surface. L Loc. $300 \mathrm{~m} \mathrm{~W}$ of Gäddtjärnen, $11 \mathrm{~F}$ NV:5a. Coord: $662690 / 145164$.

$\underline{\mathrm{J}} 75-8$

Coarse, more or less even-grained, homogeneous granite. Cf. anal. 7594253. The sample is taken approx. $70 \mathrm{~cm}$ below the weathering surface in a small road-cut. Loc. Small road-cut $100 \mathrm{~m}$ W of Lake Dammsjön, Ilf NV/5a. Coord: $66263 \% / 145240$. 
] $15-9$

Coarse, sparsely microcilne-porphyritic granıte. Cf. anal. 7594254.

The sample is taken trom the weathering surtace. Loc. $100 \mathrm{~m} W$ of Lake GIadtjärnen, IIF NV/sa. Coord: 66274I/145413.

$\underline{\mathrm{J}} 75-7$

Greyısh, microcline-porphyritic, homogeneous granite. Cf. anal. ?594252. The sample is taken trom a chunk of rock, blasted away trom a road-cut. Loc. Roar-cut, I kin SSW of Vintemossen, I if NV/sa. Coura: $662810 / 145133$.

$\mathrm{J} / \mathrm{b}-14$

Leuco-granite. The sample is taken trom the weathering surtace. Loc. Dutcrop on the southern shore of Lake Märrtjärnen, IIf NV/6a. Coord: ti63160/ 145193.

$17 b-10$

Heterogeneous leuco-granite. Ct. anal. /594:51-9. Ine sample is taken trom the weathering surtace. Loc- Outcrop $S$ of small Lake bergtjarnen, lif NV/9C. Coord: $3645830 / 146460$.

\section{$175: 11$}

Homogeneous, silght ly microciune-porphyritic granite. lt. ana ı. 1394305. The sample is taken approx. $20 \mathrm{~cm}$ below the weathering surtace in a small road-cut. LoC. Road-cut $300 \mathrm{~m}$ NW of Lake St. Kroktjarnen, I !F NV/8C. Coord: $6644 / 0 / 146455$. 
I $75-22$

Microcline-porphyritic, homogeneous granite. Cf. anal. 754308 . The Sample is taken from the weathering surface. Loc. $100 \mathrm{~m} \mathrm{SE}$ of small Lake Vitmosstjärn, 11F NV/8c. Coord: 664290/14625.

\section{IL 79-1}

Heterageneous leuco-granite. Cf I 75:16, anal. 7594307. The sample is taken some dm's below the weathering surface in a small road-cut. Loc. Roadcut E of Sandsjöäsen, llF NV/9c. Coord: $664665 / 146475$.

C $75-9$

Light, even-grained, slightly heterogeneous granite. Cf. ana1. 7594353. The sample is taken from the weathering surface. LoC. $200 \mathrm{~mW}$ of small Lake Lisastjärn, 11F NV/7d. Cord: 663990/146835.

C $75-11$

Microcline-porphyritic, homogeneous granite. Cf. anal. 7594355 . The sample is taken a few dms below the weathering surface in a small road-cut. LoC. Road-cut between Lakes Bläbärstjärnen and St. Kloten, I1F NV/7d. Coord: $663782 / 146911$.

C $75-10$

Microcline-porphyr itic, homogeneous granite. Cf. anal. 7594354. The sample is taken a few dm's below the weathering surface in a small road-cut. Loc. Road-cut $W$ of the road between Lakes Kyrktjärnen and St. Kloten, I1F NV/7d. Coord: 663866/146940. 